\title{
Jarlei Fiamoncini
}

Efeitos de dietas com diferentes conteúdos de ácidos graxos ômega-3 no metabolismo energético - modulação da função dos peroxissomos

Tese apresentada ao Programa de PósGraduação em Fisiologia Humana do Instituto de Ciências Biomédicas da Universidade de São Paulo, para obtenção do Título de Doutor em Ciências. 


\section{Jarlei Fiamoncini}

Efeitos de dietas com diferentes conteúdos de ácidos graxos ômega-3 no metabolismo energético - modulação da função dos peroxissomos

Tese apresentada ao Programa de PósGraduação em Fisiologia Humana do Instituto de Ciências Biomédicas da Universidade de São Paulo, para obtenção do Título de Doutor em Ciências.

Área de concentração: Fisiologia humana

Orientador: Prof. Dr. Rui Curi 
DADOS DE CATALOGAÇÃO NA PUBLICAÇÃO (CIP)

Serviço de Biblioteca e Informação Biomédica do

Instituto de Ciências Biomédicas da Universidade de São Paulo

reprodução não autorizada pelo autor

Fiamoncini, Jarlei.

Efeitos de dietas com diferentes conteúdos de ácidos graxos ômega-3 no metabolismo energético - modulação da função dos peroxissomos / Jarlei Fiamoncini. -- São Paulo, 2011.

Orientador: Prof Dr. Rui Curi.

Tese (Doutorado) - Universidade de São Paulo. Instituto de Ciências Biomédicas. Departamento de Fisiologia e Biofísica. Área de concentração: Fisiologia Humana. Linha de pesquisa: Metabolismo de ácidos graxos.

Versão do título para o inglês: Effects of diets with different omega-3 fatty acids content on energy metabolism - modulation of peroxisomes function

Descritores: 1. Diabetes mellitus 2. Obesidade 3. Ácidos graxos 4. PPAR 5. Tolerância à glicose 6. PUFA-n3 I. Curi, Prof. Dr. Rui II. Universidade de São Paulo. Instituto de Ciências Biomédicas. Programa de Pós-Graduação em Fisiologia Humana III. Título. 
Candidato(a):

Título da Tese:

Orientador(a):
Jarlei Fiamoncini.

Efeitos de dietas com diferentes conteúdos de ácidos graxos ômega-3 no metabolismo energético - modulação da função dos peroxissomos.

A Comissão Julgadora dos trabalhos de Defesa da Tese de Doutorado, em sessão pública realizada a ........... considerou

\section{( ) Aprovado(a) \\ ( ) Reprovado(a)}

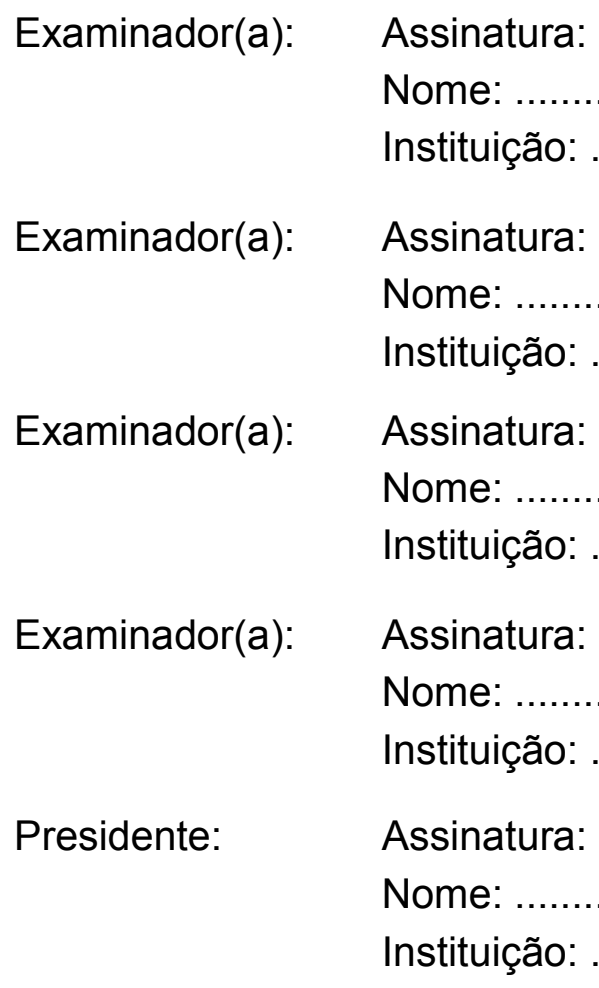




\section{Certificado}

Certificamos que o protocolo registrado sob $n^{\circ} \mathbf{0 3 6}$ nas fls. $\mathbf{3 0}$ do livro $\mathbf{2}$ para uso de animais em experimentação, sob a responsabilidade de Rui Curi, Coordenador(a) da Linha de Pesquisa "Modulação da resposta à insulina em músculo sóleo de ratos por ácidos graxos poliinsaturados ômega 3 Efeitos na fosforilação de proteinas, atividade de PPARs, produção de eicosanóides e envolvimento de cavéolas" do qual participou(aram) o(s) alunos Jarlei Fiamoncini, está de acordo com os Principios Éticos de Experimentação Animal adotado pelo Colégio Brasileiro de Experimentação Animal (COBEA) e foi aprovado pela COMISSÃO DE ÉTICA EM EXPERIMENTAÇÃO ANIMAL (CEEA) em 23.03.2006.

São Paulo, 23 de março de 2006.

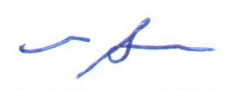

Profa. Dra. Marília C.L.Seelaender Coordenadora -CEEA - ICB/USP

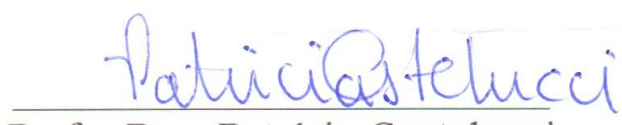

Profa. Dra. Patricia Castelucci Secretária Suplente CEEA - ICB/USP 
Aos meus pais, por tudo. 


\section{AGRADECIMENTOS}

Aos funcionários do Departamento de Fisiologia e Biofísica... Aos amigos da secretaria do departamento e do programa de pós-graduação, aos funcionários do biotério.

Ao Lab. De Fisiologia Celular, especialmente o Bob, Tati e Érica, por todo o suporte técnico... e por todas as coisas não técnicas também.

Aos amigos do laboratório de Diabetes e Metabolismo do Garvan, especialmente Donna, Elaine, Bronwyn, Anthea, Sophie, Anna, Simon, Nigel, Ted e Greg por toda ajuda e pela forma calorosa que me receberam. Aos funcionários do instituto... por toda a assistência e pela convivência.

À minha família por todo o incentivo e apoio, por terem confiado em mim mesmo não compreendendo muito bem o que eu faço. Pelo exemplo de dedicação, trabalho, honestidade e simplicidade.

Às pessoas fantásticas que encontrei no laboratório do Prof. Rui e que me escolheram como amigo. Especialmente ao Sandro, Karê, Fé, Renatas, Thaís e Talita. Pela ajuda nos experimentos, por ouvir minhas lamentações e por terem sempre vibrado comigo a cada passo. Aos que souberam a importância de se fazer presentes mesmo quando a distância física era imensa... pelas baladas, papos, barzinhos... por serem mais que big brothers... enfim, por me compreenderem.

Àqueles com quem morei nesses anos (muitos). À Neuza, por ser mãe, avó, amiga... por seu carinho e atenção... por compartilhar mais do que seu espaço comigo.

Ao Bob (Hinton), por toda a compreensão, carinho e ajuda em todas as situações. Por ter dividido comigo uma das melhores experiências que já vivi.

Aos amigos de Rodeio e Itajaí... pela constante presença e estímulo, por dividir saudades e por toda a torcida. 
Ao meu orientador e amigo Rui Curi. Não saberia como agradecer toda a compreensão e paciência nos momentos de dificuldades técnicas ou pessoais. Por toda a assistência científica, por ser um cientista brilhante, pelo seu exemplo de dedicação, caráter e amabilidade.

À FAPESP e CAPES pelo apoio financeiro ao trabalho. À Naturalis (Alexandre e Elaine) por acreditar no trabalho e contribuir com sua realização. 


\section{Resumo}

FIAMONCINI, J. Efeitos de dietas com diferentes conteúdos de ácidos graxos ômega-3 no metabolismo energético - modulação da função dos peroxissomos. 2011. $111 \mathrm{f}$. Tese (Doutorado em Fisiologia Humana) - Instituto de Ciências Biomédicas, Universidade de São Paulo, São Paulo, 2011.

Dietas hiperlipídicas ricas em ácidos graxos (AG) saturados induzem acúmulo de mediadores lipídicos envolvidos no desenvolvimento da resistência à insulina em diversos tecidos. Por outro lado, os ácidos graxos poliinsaturados ômega-3 (PUFA n-3) ativam o fator de transcrição Peroxisome Proliferator Activated Receptor (PPAR), induzindo oxidação de lipídios. Neste estudo, camundongos machos da linhagem Swiss foram tratados com dieta controle (chow) ou com dietas contendo óleo de peixe a $4 \%$ (NFO) e 40\% (HFO) ou banha de suínos a 4\% (NL) e 40\% (HL) por oito semanas. Investigou-se o metabolismo de carboidratos e lipídios no fígado e músculo esquelético. Os camundongos do grupo HFO apresentaram depósitos menores de tecido adiposo e menor eficiência energética em relação ao grupo HL. $\mathrm{O}$ decaimento da glicemia durante o teste de tolerância à insulina (ITT), a captação de 2-desoxi-glicose e a incorporação de glicose em glicogênio no músculo sóleo isolado em resposta à insulina não foi diferente entre os grupos. Por outro lado, nos grupos NFO e HFO, a área sob a curva glicêmica no teste de tolerância à glicose (GTT) foi menor em relação aos grupos NL e HL, refletindo aumento da responsividade do fígado à insulina ou maior secreção de insulina pelas células $\beta$ pancreáticas. $O$ conteúdo de triacilgliceróis e a oxidação de ácido palmítico em músculo esquelético foram semelhantes entre os grupos. Em contraste, os animais tratados com óleo de peixe apresentaram cerca de $60 \%$ menos triacilgliceróis no fígado que os animais dos grupos NL e HL. Os camundongos do grupo HFO apresentaram menor consumo de oxigênio, avaliado por calorimetria indireta, e menor produção de $\mathrm{CO}_{2}$ a partir do ácido palmítico em homogenatos de fígado. Apesar destes resultados indicarem redução no metabolismo oxidativo, foi observada, neste grupo, produção $50 \%$ maior de moléculas provenientes da $\beta$-oxidação do ácido palmítico em homogenatos de fígado, evidenciando aumento no fluxo de metabólitos nesta via. A elevação observada na atividade da acil CoA oxidase (ACO) - uma enzima peroxissomal e de outras enzimas envolvidas na $\beta$-oxidação no fígado de animais do grupo HFO, 
associada ao maior conteúdo do marcador peroxissomal PMP-70, indicam aumento na oxidação peroxissomal de AG. A elevação do número e atividade dos peroxissomos pode direcionar os esqueletos de carbono gerados na $\beta$-oxidação para a síntese de outras moléculas como ácidos biliares, que são excretados nas fezes. Além disso, como a $\beta$-oxidação peroxissomal de $A G$ é energeticamente ineficiente, a menor produção de ATP por mol de AG oxidado acarreta na metabolização de maior número de moléculas de AG para gerar energia. Estas alterações no metabolismo energético, associadas à diminuição da lipogênese no grupo HFO, contribuem para a redução do acúmulo de lipídios e preservação da tolerância à glicose.

Palavras-chave: Ácidos graxos. Resistência à insulina. Peroxissomos. Diabetes tipo 2. Obesidade. $\beta$-Oxidação. 


\section{Abstract}

FIAMONCINI, J. Effects of diets with different omega 3 fatty acids content on energy metabolism - modulation of peroxisomes function. $2011.111 \mathrm{p}$. Ph. D. thesis (Human Physiology) - Instituto de Ciências Biomédicas, Universidade de São Paulo, São Paulo, 2011.

High-fat diets rich in saturated fatty acids (FA) induce accumulation of lipid mediators involved in the development of insulin resistance in different tissues. On the other hand, omega-3 polyunsaturated fatty acids ( $n-3$ PUFA) are well known activators of the transcription factor Peroxisome Proliferator Activated Receptor (PPAR), inducing FA oxidation. In this study, male Swiss mice were fed on control diet (chow) or diets containing either fish oil at 4\% (NFO) and 40\% (HFO) or lard at 4\% (NL) and 40\% $(\mathrm{HL})(\mathrm{wt} / \mathrm{wt})$ for eight weeks. Carbohydrate and lipid metabolism were investigated in the liver and skeletal muscle. The HFO group showed smaller fat pads and lower energy efficiency, when compared to the HL group. Glucose clearance during the insulin tolerance test (ITT), uptake of 2-deoxy-glucose and incorporation of glucose into glycogen in isolated soleus muscle in response to insulin stimulation were not different among the groups. On the other hand, in the NFO and HFO groups, the area under the glycemic curve during the glucose tolerance test (GTT) was reduced in comparison to the $\mathrm{NL}$ and $\mathrm{HL}$ groups. Triacylglycerol content and palmitate oxidation by the gastrocnemius muscle were not different among the groups. In contrast, fish oil-fed mice showed $60 \%$ less liver triacylglycerol content than lard-fed mice. The HFO group showed reduced oxygen consumption, as determined through indirect calorimetry, and reduced $\mathrm{CO}_{2}$ production from palmitic acid in liver homogenates. Despite the reduced oxidative metabolism, it was observed, in the HFO group, $50 \%$ increase in generation of molecules from palmitic acid $\beta$-oxidation (ASM) in liver homogenates, indicating increased metabolite flux through this pathway. The increased activity of the peroxisomal acyl-CoA oxydase (ACO) and other enzymes involved in $\beta$-oxidation in the liver of HFO mice and the increased content of the peroxisomal marker PMP-70 point towards increased peroxisomal FA oxidation. The increase in the pool size and activity of peroxisomes can possibly direct the carbon skeletons generated through $\beta$-oxidation to the synthesis of other molecules such as bile acids, that are excreted in the feces. As peroxisomal $\beta$ - 
oxidation of FA is energetically inefficient, the lower ATP generation per mol of FA oxidised creates the need of metabolising more FA molecules to generate energy. These alterations in energy metabolism, associated to decreased lipogenesis in the HFO group, contribute to the reduced lipid accumulation and preserved glucose tolerance.

Key words: Fatty acids. Insulin resistance. Peroxisomes. Type 2 Diabetes. Obesity. $\beta$-Oxidation. 


\section{Lista de llustrações}

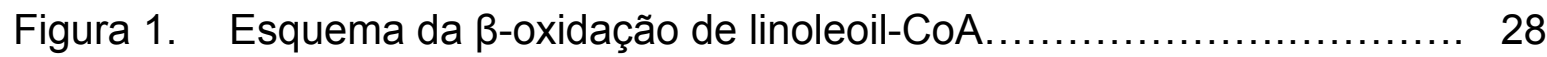

Figura 2. Comparação entre a $\beta$-oxidação mitocondrial e a peroxissomal...... 31

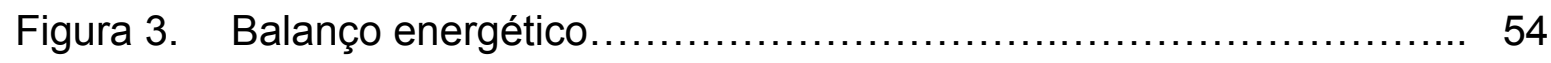

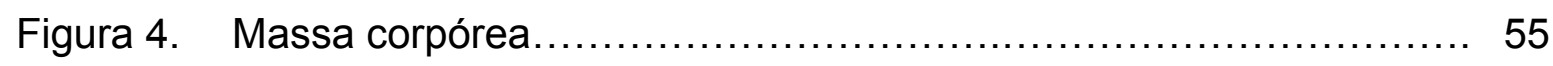

Figura 5. Curva de ganho de massa corpórea........................... 56

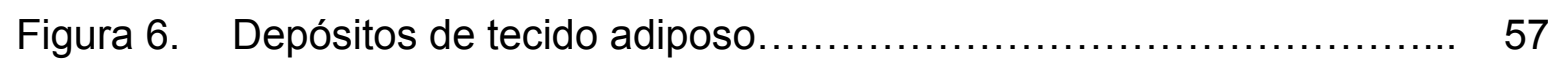

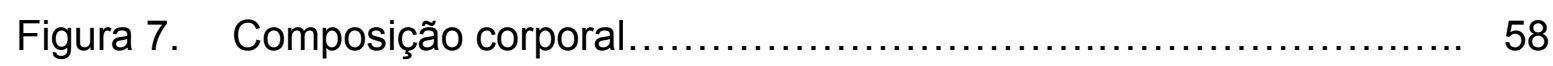

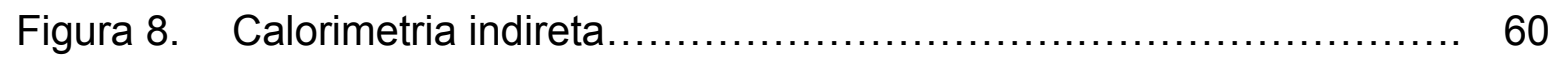

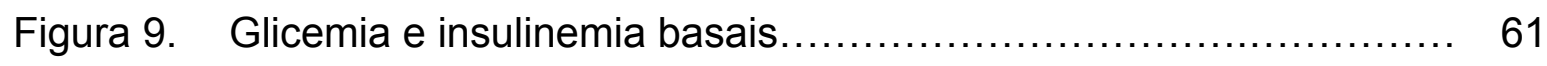

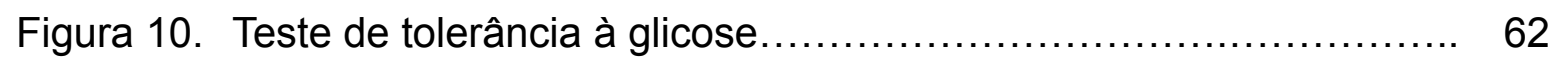

Figura 11. Teste de tolerância à insulina................................ 63

Figura 12. Captação de glicose e síntese de glicogênio em músculo isolado... 64

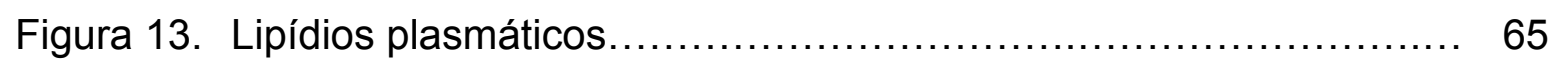

Figura 14. Conteúdo de lipídios no fígado e músculo gastrocnêmio............ 66

Figura 15. Oxidação de ácido palmítico in vitro........................... 67

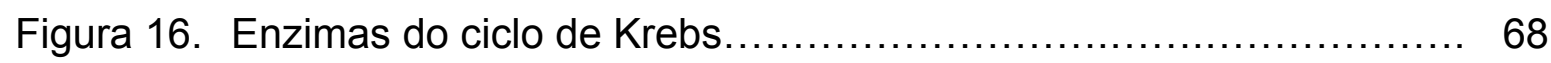

Figura 17. Enzimas da $\beta$-oxidação.................................... 69

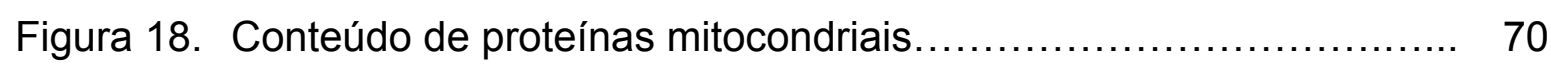

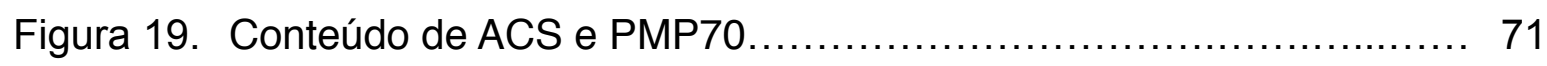

Figura 20. Wy-14,643 e oxidação de ácido palmítico...................... 71

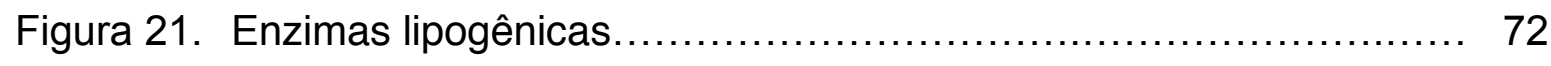

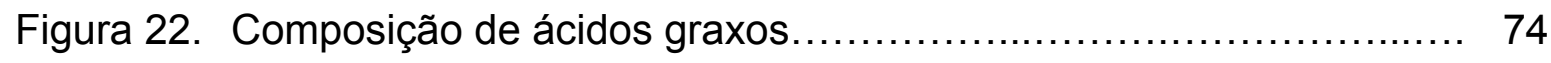

Figura 23. Razão dos ácidos graxos monoinsaturados / ácidos graxos

Figura 24. Mecanismo de ação dos PUFA n-3 na preservação da tolerância à 84 


\section{Lista de Tabelas}

Tabela 1 - Nomenclatura dos ácidos graxos............................... 23

Tabela 2 - Ingredientes e conteúdo energético das dietas.................. 45

Tabela 3 - Composição de ácidos graxos nas dietas....................... 46

Tabela 4 - Cálculo do consumo de oxigênio pela oxidação de ácidos 81 


\section{Lista de Abreviaturas e Siglas}

\begin{tabular}{|c|c|}
\hline ACC & Acetil CoA carboxilase \\
\hline $\mathrm{ACO}$ & Acil CoA oxidase \\
\hline ACS & Acil CoA sintetase \\
\hline ADP & Difosfato de adenosina \\
\hline AG & Ácido graxo \\
\hline AGS & Ácido graxo sintase \\
\hline AIN 93 & Formulação para dietas de roedores do American Institute of Nutrition \\
\hline Akt ou PKB & Proteína quinase B \\
\hline ANOVA & Análise de variância \\
\hline ASM & Metabólitos solúveis em ácido \\
\hline BHAD & Desidrogenase de acil CoAs beta-hidroxilados \\
\hline Chow & Neste texto será a denominação do grupo referência ou controle \\
\hline CoA & Coenzima A \\
\hline СРT & Carnitina palmitoil transferase \\
\hline CS & Citrato sintase \\
\hline CTE & Cadeia de transporte de elétrons \\
\hline DEXA & Absorciometria de raios $X$ de feixe duplo \\
\hline DHA & Ácido docosahexaenóico \\
\hline EPA & Ácido eicosapentaenóico \\
\hline FAD & Flavina adenina dinucleotídio \\
\hline $\mathrm{FADH}_{2}$ & Flavina adenina dinucleotídio reduzida \\
\hline FID & Detector de ionização de chama \\
\hline
\end{tabular}


GC

Cromatografia gasosa

GDT Difosfato de guanosina

Glut-4 Transportador de glicose (isoforma 4)

GSK-3 Glicogênio sintase quinase (isoforma 3)

GTP Trifosfato de guanosina

GTT Teste de tolerância à glicose

HFO Grupo de camundongos tratado com dieta hiperlipídica à base de óleo de peixe

$\mathrm{HL} \quad$ Grupo de camundongos tratado com dieta hiperlipídica à base de banha

IRS 1 e 2 Substrato do receptor da insulina (isoformas 1 e 2)

ITT Teste de tolerância à insulina

IUPAC União internacional de química pura e aplicada

MAP Proteína ativada por mitógenos

MAPK Quinase da proteína ativada por mitógenos

MCAD Desidrogenase de acil CoAs de cadeia média

MTE Tioesterase-1 mitocondrial

$\mathrm{NADH} \quad$ Nicotinamida adenina dinucleotídeo reduzida

$\mathrm{NAD}^{+} \quad$ Nicotinamida adenina dinucleotídeo oxidada

NADPH Fosfato de nicotinamida adenina dinucleotídeo reduzida

NEFA Ácido graxo não esterificado

NFO Grupo de camundongos tratado com dieta normolipídica à base de óleo de peixe

NL Grupo de camundongos tratado com dieta normolipídica à base de banha

PPAR Receptor ativado por proliferadores de peroxissomos

$\mathrm{Pi} \quad$ Fosfato inorgânico 


\begin{tabular}{|c|c|}
\hline PI3K & Quinase 3 de fosfoinositídio \\
\hline PKC & Proteína quinase $\mathrm{C}$ \\
\hline PMP-70 & Proteína da membrana peroxissomal 70 \\
\hline PUFA & Ácido graxo poliinsaturado \\
\hline PUFA n-3 & Ácido graxo poliinsaturado da família ômega 3 \\
\hline PUFA n-6 & Ácido graxo poliinsaturado da família ômega 6 \\
\hline PVDF & Fluoreto de polivinilidina \\
\hline RER & Quociente respiratório $\left(\mathrm{VCO}_{2} / \mathrm{VO}_{2}\right)$ \\
\hline $\mathrm{RXR}$ & Receptor ativado por retinol \\
\hline $\mathrm{SDH}$ & Succinato desidrogenase \\
\hline SDS-PAGE & Eletroforese em gel de poliacrilamida com dodecil sulfato de sódio \\
\hline TAE & Tecido adiposo epididimal \\
\hline TAI & Tecido adiposo inguinal \\
\hline TAR & Tecido adiposo retroperitoneal \\
\hline TAS & Tecido adiposo subcutâneo \\
\hline TLC & Cromatografia em camada delgada \\
\hline UCP & Proteína desacopladora mitocondrial \\
\hline $\mathrm{VCO}_{2}$ & Produção de dióxido de carbono \\
\hline $\mathrm{VO}_{2}$ & Consumo de oxigênio \\
\hline Wy-14,643 & Ácido piriníxico \\
\hline
\end{tabular}




\section{Sumário}

1 Apresentação

2 Introdução e Revisão da Literatura 21

2.1 A química dos ácidos graxos $\quad 21$

2.2 Síntese dos ácidos graxos 24

2.3 Oxidação de ácidos graxos 26

2.4 ß-oxidação mitocondrial 26

2.5 Biologia dos peroxissomos e a $\beta$-oxidação peroxissomal 28

2.6 Insulina 32

2.7 Efeitos dos ácidos graxos nas respostas à insulina 33

2.7.1 Ciclo de Randle $\quad 35$

2.7.2 Inibição da sinalização à insulina 35

2.7.3 Metabólitos lipídicos envolvidos na resistência à insulina 36

2.7.4 A composição dos lipídios da membrana e a sinalização à insulina 37

2.7.5 Ácidos graxos e modulação da expressão gênica 38

2.7.6 Ácidos graxos e receptores ativados por proliferados de peroxissomos 39

$\begin{array}{ll}2.8 \text { Ácidos graxos e obesidade } & 40\end{array}$

3 Hipótese $\quad 42$

4 Objetivos 43

$\begin{array}{ll}4.1 \text { Objetivos gerais } & 43\end{array}$

$\begin{array}{ll}4.2 \text { Objetivos específicos } & 43\end{array}$

5 Materiais e métodos $\quad 44$

5.1 Modelo animal 44

5.2 Desenho experimental 44

5.3 Balanço energético e composição corporal 46

5.4 Determinação do gasto energético 47

$\begin{array}{ll}5.5 \text { GTT e ITT } & 48\end{array}$ 
5.6 Captação de glicose e síntese de glicogênio em músculo sóleo

5.7 Determinação de metabólitos lipídicos 49

5.8 Oxidação do ácido palmítico 49

5.9 Avaliação da atividade das enzimas da $\beta$-oxidação e ciclo de Krebs 50

5.10 Western Blotting 50

5.11 Experimento com o agonista de PPAR Wy-14,643 51

5.12 Análise estatística 51

6 Resultados

6.1 Balanço energético 53

6.2 Composição corporal e ingestão energética 55

6.3 Consumo de oxigênio 58

6.4 Homeostase glicêmica $\quad 61$

6.5 Concentrações de lipídios no plasma e tecidos e oxidação de ácidos graxo $\mathrm{s}$

6.6 Atividade mitocondrial e peroxissomal 68

$\begin{array}{ll}\text { 6.7 Lipogênese } & 72\end{array}$

7 Discussão 76

8 Conclusão $\quad 85$

Referências * $\quad 86$ 


\section{Apresentação}

A prevalência de diabetes mellitus tipo 2 aumentou muito nas últimas décadas, elevando a ocorrência de complicações como retinopatia, neuropatia, nefropatia e doenças cardiovasculares (AMOS; MCCARTY; ZIMMET, 1997). Além da influência de fatores genéticos, aspectos ambientais e comportamentais como atividade física e dieta são muito importantes no desenvolvimento e evolução da obesidade e do diabetes tipo 2. A maior oferta de alimentos ricos em lipídios, mesmo para populações com baixo poder aquisitivo, aumenta o número de indivíduos suscetíveis a estas doenças. O número de diabéticos em 1995 era de 135 milhões e a estimativa para 2020 é de 300 milhões (SEIDELL, 2000).

Apesar da semelhança entre os ácidos graxos (AG), diferenças sutis na sua estrutura são suficientes para alterar radicalmente seu metabolismo e função. A compreensão destes processos é o passo inicial para se desenvolver estratégias visando a prevenir as consequências da ingestão excessiva, ou ainda, utilizá-los na terapia para obesidade e diabetes tipo 2. 


\section{Introdução e Revisão da Literatura}

\subsection{A química dos ácidos graxos}

Os lipídios constituem um grupo de moléculas muito distintas entre si, sendo a insolubilidade em água sua característica comum. A estrutura fundamental das moléculas lipídicas de maior abundância é composta por ácidos graxos (AG) ácidos carboxílicos representados pela fórmula $\mathrm{R}-\mathrm{CO}_{2} \mathrm{H}$. Em mamíferos, o radical $\mathrm{R}$ é geralmente uma cadeia hidrocarbônica longa, não ramificada, com número par de átomos de carbono, podendo ser saturada ou conter uma ou mais insaturações. São moléculas anfipáticas, onde o grupo carboxila constitui a região polar e a cadeia $\mathrm{R}$ a região apolar da molécula.

Quanto ao tamanho da cadeia carbônica, os AG podem ser classificados em AG de cadeia curta (contém dois a quatro átomos de carbono), cadeia média (seis a quatorze átomos de carbono), cadeia longa (quando contêm mais de quatorze átomos de carbono) e cadeia muito longa (número de carbonos igual ou maior que vinte).

A presença de insaturações (duplas ligações) na cadeia carbônica classifica os AG em saturados - sem insaturações na cadeia carbônica, monoinsaturados quando contém uma insaturação na cadeia carbônica e poliinsaturados (PUFA) com mais de uma insaturação.

As duplas ligações podem se apresentar na configuração cis ou trans. $\mathrm{Na}$ configuração cis, os átomos de hidrogênio ligados aos átomos de carbono adjacentes à dupla ligação estão do mesmo lado da cadeia hidrocarbônica, ao passo que na dupla ligação trans, os átomos de hidrogênio ligados aos átomos de carbono unidos pela dupla ligação estão em lados opostos da cadeia. A rigidez da dupla ligação mantém a conformação da molécula e, no caso do isômero cis, causa o curvamento da cadeia, restringindo a liberdade conformacional do AG. Quanto mais duplas ligações na configuração cis, menor será a sua flexibilidade. As duplas ligações trans não causam curvamento da cadeia hidrocarbônica e por isso AG com duplas ligações nesta configuração apresentam estrutura espacial similar à de $A G$ saturados. Disto resulta que lipídios compostos majoritariamente por $A G$ insaturados e poliinsaturados apresentam menor ponto de fusão e se encontram no estado líquido à temperatura 
ambiente, sendo denominados genericamente de óleos. Lipídios compostos por AG de cadeia saturada apresentam-se sólidos à temperatura ambiente e são chamados de gorduras.

Comumente, os AG são identificados por nomes que não seguem qualquer regra e geralmente derivam da fonte da qual o $A G$ foi primeiramente isolado. É formado pela palavra ácido + o nome comum (variável), sucedido do sufixo ico, relacionado à natureza ácida da molécula. Como exemplos, temos o ácido palmítico, abundante no óleo de palma e o ácido oléico encontrado em altas concentrações no óleo de oliva. A nomenclatura dos AG pelo sistema IUPAC (International Union of Pure and Applied Chemistry) é baseada nas regras para nomenclatura em química orgânica, publicadas em 1977 e uma recomendação específica para lipídios de 1979. Neste sistema, os átomos de carbono recebem números a partir do grupamento carboxila e os AG são representados descrevendo-se a configuração e posição das duplas ligações, quando existentes, seguido do nome que descreve o número de átomos de carbono e de duplas ligações da molécula. Os nomes sempre terminam com o sufixo óico. Neste sistema, o ácido palmítico é descrito "nhexadecanóico" e o ácido oléico "cis- $\Delta 9$-octadecenóico". Existe ainda um sistema com nomes abreviados para os AG, muito mais simples e descritivo. Dessa forma, descreve-se o AG de acordo com o número de átomos de carbono + o número de duplas ligações (caso existam), separados por dois pontos, seguidos pela posição e configuração da dupla ligação. Dessa forma, o ácido palmítico é representado por 16:0, por apresentar 16 átomos de carbono e nenhuma dupla ligação e o ácido oléico por 18:1n-9c. Os principais AG encontrados em tecidos de mamíferos e as diferentes formas de descrevê-los, seguindo os sistemas de nomenclatura estão na Tabela 1.

A classificação dos AG insaturados pode ser feita de duas formas: na nomenclatura delta $(\Delta)$ descreve-se a posição da primeira dupla ligação existente a partir do carbono do grupo carboxila, precedida da configuração da dupla ligação. Por exemplo, o ácido linoléico, que contém duas duplas ligações na configuração cis nos carbonos 9 e 12, contando-se a partir da carboxila é representado por 18:2 cis$\triangle 9$. Na segunda forma de representar os PUFA (a mais comum), indica-se a posição da dupla ligação mais próxima do carbono do terminal metila, ou carbono ômega $(\omega)$, designado dessa forma por ser o último carbono da cadeia hidrocarbônica, 
assim como a letra $\omega$ é a última do alfabeto grego. Pode-se também substituir a letra $\omega$ pela letra "n". Este sistema classifica os PUFA em quatro classes distintas: $\omega-7$, $\omega-9, \omega-6$ e $\omega-3$, de acordo com a localização da primeira dupla ligação em relação ao carbono $\omega$. Dessa forma, o ácido a-linolênico, que tem 18 átomos de carbono e 3 duplas ligações, sendo a primeira a 3 átomos de carbono do terminal metila é descrito como 18:3w3 ou 18:3n3 e o ácido linoléico que tem 18 átomos de carbono e 2 duplas ligações na configuração cis, sendo a primeira a 6 carbonos do metil terminal, é referido como 18:2n6. Pode-se ainda indicar a configuração desta dupla ligação: 18:2n6c.

Tabela 1- Nomenclatura dos ácidos graxos. Relação dos ácidos graxos de ocorrência mais abundante em tecidos de animais de mamíferos.

\begin{tabular}{lll}
\hline Abreviatura & Nome Comum & Nome IUPAC \\
\hline Saturados & & \\
$14: 0$ & Ácido mirístico & n-tetradecanóico \\
$16: 0$ & Acido palmítico & n-hexadecanóico \\
$18: 0$ & Acido esteárico & n-octadecanóico
\end{tabular}

\section{Monoinsaturados}

$\begin{array}{lll}16: 1 \mathrm{n} 7 & \text { Ácido palmitoléico } & \text { cis- } \Delta 9 \text {-hexadecenóico } \\ 18: 1 \mathrm{n} 9 & \text { Ácido oléico } & \text { cis- } \Delta 9 \text {-octadecenóico }\end{array}$

\section{PUFA n-6}

$\begin{array}{lll}18: 2 n 6 & \text { Ácido linoléico } & \text { cis- } \Delta 9, \Delta 12, \Delta 15 \text {-octadecenóico } \\ 20: 4 n 6 & \text { Ácido araquidônico } & \text { cis- } \Delta 5, \Delta 8, \Delta 11, \Delta 14 \text {-eicosatetraenóico }\end{array}$

\section{PUFA n-3}

$\begin{array}{lll}\text { 18:3n3 } & \text { Ácido a-linolênico } & \text { cis- } \Delta 9, \Delta 12, \Delta 15 \text {-octadecatrienóico } \\ 20: 5 n 3 & \text { Ácido timnodóico (EPA) } & \text { cis-5,1,11,14,17-eicosapentaenóico } \\ 22: 6 n 3 & \text { Ácido cervônico (DHA) } & \text { cis-4,7,10,13,16,19-docosahexaenóico }\end{array}$




\subsection{Síntese dos ácidos graxos}

Em mamíferos, a síntese dos AG ocorre no citoplasma da maioria das células a partir do acetil CoA. Este metabólito, formado no interior das mitocôndrias, se junta com o oxaloacetato para formar citrato, que é transportado para o citoplasma, onde é convertido em oxaloacetato e acetil-CoA. A acetil CoA carboxilase (ACC) que catalisa a formação de malonil-CoA a partir de duas moléculas de acetil $\mathrm{CoA}$, sendo este o primeiro passo irreversível da via de síntese de AG. A ACC é o principal sítio de regulação da síntese de $A G$. Sua atividade é aumentada pelo citrato e inibida por AG de cadeia longa, além de ser modulada por fosforilação mediada por hormônios como a insulina.

Os AG são sintetizados a partir de ciclos de adições de pares de carbono a uma molécula de malonil-CoA original catalisadas por um complexo multienzimático - a ácido graxo sintase (AGS). Os átomos de carbono dos AG são adicionados em uma seqüência de passos, sendo o grupo acila produzido por este conjunto de reações reciclado para tornar-se substrato em uma nova reação de condensação com o grupo malonil-CoA ativado. Quando o comprimento da cadeia do grupo acila atinge dezesseis átomos de carbono, o produto (ácido palmítico) abandona o ciclo (COX, 2005).

O ácido palmítico é o precursor para a síntese de outros AG mais longos e insaturados por meio de reações de elongação (adição de átomos de carbono) e dessaturação (inserção de duplas ligações). As reações de dessaturação são realizadas por um complexo enzimático que requer $\mathrm{NADH}, \mathrm{O}_{2}$ e três enzimas ligadas à membrana do retículo endoplasmático: citocromo $b_{5}$ redutase, citocromo $b_{5}$ e uma dessaturase. Este sistema produz os $A G$ monoinsaturados mais comuns nos tecidos animais: ácido palmitoléico (16:1n7) e ácido oléico (18:1n9). A maioria dos AG monoinsaturados produzidos por animais apresentam a dupla ligação na posição 9 . Apenas em vegetais, novas duplas ligações são introduzidas entre a insaturação existente e o grupo metil terminal, gerando os ácidos linoléico (18:2n6) e a-linolênico (18:3n3) a partir do ácido oléico.

Por serem produzidos apenas em vegetais, mas indispensáveis ao bom funcionamento do organismo animal, os ácidos linoléico e a-linolênico são considerados essenciais e devem ser obtidos pelo consumo de vegetais ou de 
animais herbívoros (POMPÉIA, 2002). No organismo dos mamíferos, os AG essenciais obtidos da dieta podem sofrer novas reações de elongação e dessaturação. $O$ ácido linoléico é precursor do ácido araquidônico, que é o principal produto desta via em mamíferos, mas que também pode dar origem a outros AG. De maneira análoga, o ácido a-linolênico sofre dessaturações e elongações para gerar os PUFA EPA e DHA e outros membros da família n-3. Entre os membros das diferentes famílias de $A G$ (n-3 e n-6), há competição pelas enzimas que atuam na sua metabolização. A $\Delta-6$ dessaturase, que controla uma etapa limitante da dessaturação, apresenta maior afinidade pelo ácido a-linolênico (PUFA n-3) em relação ao linoléico (PUFA n-6) (RIECKENHOFF; HOLMAN; BURR, 1949). Os ácidos araquidônico, EPA e di-homo- $\gamma$-linolênico, produzidos na metabolização dos AG essenciais, dão origem a uma série de mediadores químicos de relevância fisiológica, dentre os quais destacam-se as prostaglandinas, leucotrienos e tromboxanas (DAS e FAMS, 2003).

A essencialidade dos PUFA n-6 foi descrita na década de 1920, quando se observaram diversas alterações funcionais associadas à sua ausência (BURR, 1929). Já os PUFA n-3 foram considerados essenciais após a década de 1980 , associando-se a sua falta a deficiências neurológicas e visuais (HOLMAN, 1998). Além dos efeitos na derme e sistema nervoso, a ausência de AG essenciais também causa alterações em outros órgãos e sistemas, basicamente devido a falta de mediadores lipídicos com ação farmacológica. As síndromes causadas pela deficiência de AG n-3 ou n-6 podem ser revertidas pelo fornecimento de qualquer AG da classe em deficiência, pois é possível que, dentro da mesma classe, os AG sejam interconvertidos. Entretanto, a ausência de PUFA n-3 não pode ser revertida pelo fornecimento de PUFA n-6 e vice-versa porque os mamíferos não podem retirar ou inserir insaturações nas posições 3-4 ou 6-7 dos PUFA (POMPÉIA, 2002). 


\subsection{Oxidação de ácidos graxos}

Em estudos pioneiros na utilização de marcadores sintéticos para estudar processos bioquímicos, Franz Knoop, em 1904, observou que os AG são degradados pela oxidação do carbono $\beta$, cunhando 0 nome $\beta$-oxidação para 0 processo de oxidação de AG (STRYER, 1988). Em 1949, Eugene Kennedy e Albert Lehninger mostraram que a oxidação de AG ocorre nas mitocôndrias e apenas em 1976 Lazarow e De Duve descreveram este processo também em peroxissomos.

No interior das células, antes de qualquer processo metabólico, os AG são ativados pela sua ligação à coenzima $A(C \circ A)$ no citoplasma, dando origem a moléculas de acil CoA. Este processo é catalisado por um grupo de acil CoA sintetases que difere quanto à sua localização celular e especificidade (COLEMAN; LEWIN; MUOIO, 2000). A oxidação completa de AG compreende dois processos: a $\beta$-oxidação, onde as moléculas de acil CoA são convertidos em moléculas de acetil $\mathrm{CoA}$, e o ciclo de Krebs, onde as moléculas de acetil CoA geradas na $\beta$-oxidação são oxidadas a $\mathrm{CO}_{2}$.

\section{$2.4 \beta$-oxidação mitocondrial}

Nas mitocôndrias, o processo da $\beta$-oxidação é altamente regulado. A entrada das moléculas de acil CoA nestas organelas é a principal etapa de regulação da oxidação de AG sendo mediada pelo sistema carnitina palmitoil transferase (CPT). A CPT-1, localizada na membrana mitocondrial externa, catalisa a conversão do acil CoA em acil carnitina. As moléculas de acil-carnitina podem ser formadas no espaço intermembranas da mitocôndria ou migrar para este espaço através de poros da membrana mitocondrial externa. Estas moléculas podem então atravessar a membrana mitocondrial interna através do transportador acil-carnitina /carnitina. O terceiro e último passo do sistema carnitina palmitoil transferase é a transferência do grupo acil da carnitina para uma molécula de CoA na matriz mitocondrial, catalisada pela enzima CPT-2. O malonil CoA, formado pela ACC em condições de grande disponibilidade de glicose, é o inibidor alostérico mais importante da CPT-1 (KERNER e HOPPEL, 2000). A síntese de malonil CoA é o primeiro passo da via de síntese de AG. A ação deste sobre o transporte de AG para a mitocôndria inibe a 
oxidação desses quando a síntese de novo é favorecida em consequência da alta disponibilidade de glicose (WAKIL; STOOPS; JOSHI, 1983).

Uma vez o acil CoA estando na matriz mitocondrial, este pode sofrer $\beta$ oxidação. Este processo consiste de quatro passos, através dos quais uma molécula de acetil CoA é gerada às custas da retirada de dois átomos de carbono da cadeia hidrocarbônica do acil-CoA, gerando uma molécula de $\mathrm{FADH}_{2}$ e $\mathrm{NADH}$. A repetição deste ciclo de reações acontece quantas vezes for necessário para que a molécula de acil CoA seja convertida em várias moléculas de acetil CoA, sendo o número destas dependente do tamanho da cadeia carbônica do AG. Por exemplo, o ácido palmítico, que contém 16 átomos de carbono gera 8 moléculas de acetil CoA.

O primeiro passo da $\beta$-oxidação é uma desidrogenação do acil CoA, inserindo uma dupla ligação trans entre os carbonos C2 e C3, catalisada pela acil CoA desidrogenase, causando redução do $F A D$ a $F A D H_{2}$. A acil CoA desidrogenase apresenta diferentes isoformas, com especificidades distintas para acil CoAs de tamanhos diferentes. O segundo passo da $\beta$-oxidação é a hidratação da dupla ligação gerada anteriormente, catalisada pela enoil CoA hidratase. No terceiro passo, a $\beta$-hidroxiacil CoA desidrogenase catalisa a desidrogenação da molécula gerada no segundo passo da via, com a concomitante redução do NAD+ à NADH. O quarto e último passo da via é catalisado pela tiolase, que adiciona uma molécula de CoA ao acil CoA, culminando com a formação de uma molécula de acetil CoA e outra de acil CoA encurtada em dois átomos de carbono. As três últimas enzimas da via apresentam-se em um complexo trifuncional no fígado de humanos e roedores (COX, 2005).

Nas mitocôndrias, as moléculas de $\mathrm{FADH}_{2}$ e $\mathrm{NADH}$ produzidas na $\beta$-oxidação doam seus elétrons para a cadeia transportadora de elétrons (CTE), cuja atividade culmina na produção de ATP a partir de $\mathrm{ADP}+\mathrm{Pi}$, redução do $\mathrm{O}_{2}$ e produção de $\mathrm{H}_{2} \mathrm{O}$. Além disso, as moléculas de acetil CoA geradas entram no ciclo de Krebs, para serem oxidadas a $\mathrm{CO}_{2}$, gerando outras moléculas de $\mathrm{FADH}_{2}, \mathrm{NADH}$ e GTP.

A oxidação de PUFA requer duas etapas adicionais, em relação à dos AG saturados. Duplas ligações em carbonos pares precisam ser metabolizadas para que prossiga a sequência de ciclos da $\beta$-oxidação. Estas reações são catalisadas pela 2,4-dienoil-CoA redutase que é dependente de NADPH. Esta enzima reduz uma dupla ligação na molécula $\Delta 2$-trans, $\Delta 4$-cis enoil CoA gerando $\Delta 3$-trans enoil CoA, 
que é convertido a $\Delta 2$-trans enoil CoA pela $\Delta 3, \Delta 2$ trans enoil CoA isomerase (SMELAND et al., 1992). A Figura 1 apresenta a reação catalisada pela enzima 2,4dienoil-CoA redutase em um esquema da $\beta$-oxidação do linoleoil-CoA, gerado a partir do ácido linoléico e, portanto, contendo uma dupla ligação em um carbono par.

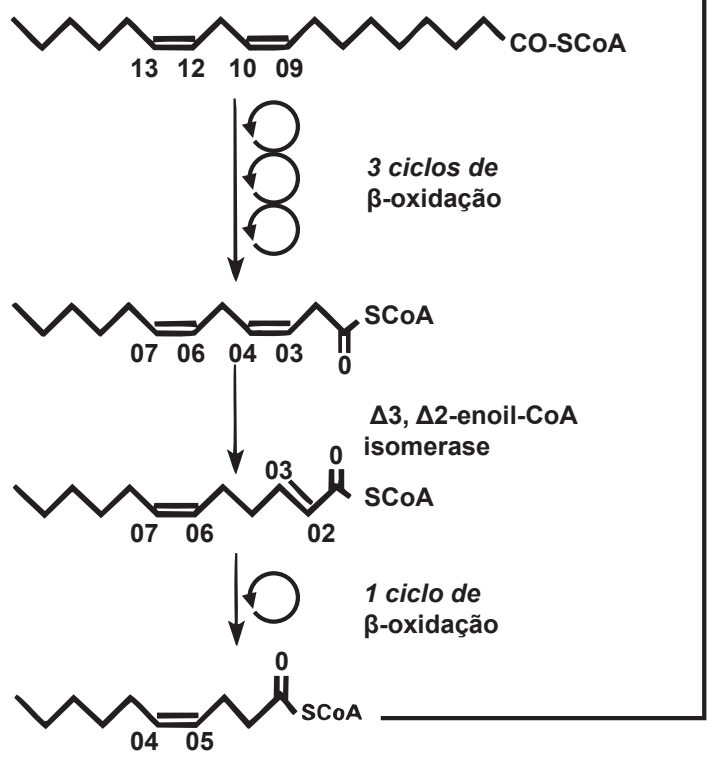

Acil-CoA desidrogenase

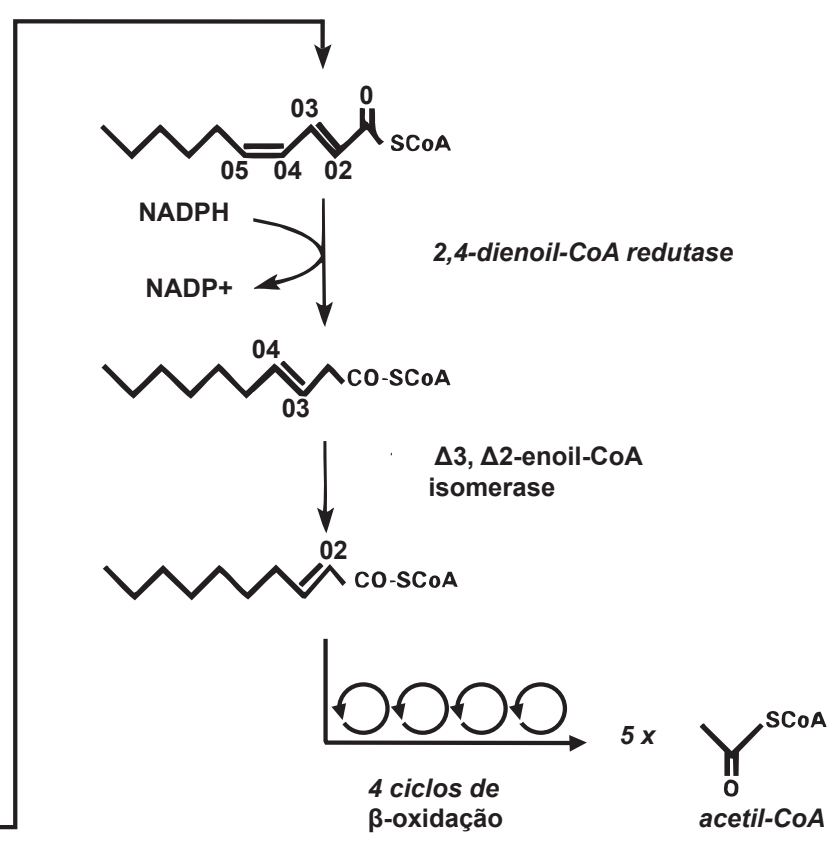

Figura 1. Esquema da $\beta$-oxidação de linoleoil-CoA. $O$ diagrama mostra a reação adicional necessária para a $\beta$-oxidação do ácido linoléico, evidenciando a participação da 2,4 dienoil CoA redutase.

Fonte: Adaptado de Wanders et al. (1999).

\subsection{Biologia dos peroxissomos e a $\beta$-oxidação peroxissomal}

Os peroxissomos são organelas com diâmetro entre 0,1 - $1 \mu \mathrm{m}$, envoltas por uma membrana simples, contendo matriz granulosa que pode apresentar inclusões cristalinas de enzimas (SCHRADER e FAHIMI, 2008). Estas organelas foram descritas pela primeira vez em 1954 por Rhodin, que as chamou de microssomos. Somente em 1966, De DuVe e Baudhuin os isolaram pela primeira vez em mamíferos a partir do fígado de ratos. Estes autores também descreveram a 
presença de enzimas geradoras de $\mathrm{H}_{2} \mathrm{O}_{2}$ e da catalase nestas organelas, fato que os levou a cunhar o nome peroxissomos.

A primeira descrição de um sistema capaz de oxidar AG fora das mitocôndrias foi feita em 1969 em glioxissomos de sementes de mamona (COOPER e BEEVERS, 1969). Durante a germinação, os glioxissomos tem a função de prover esqueletos de carbono a partir de moléculas de lipídios enquanto as estruturas fotossintetizantes não estão presentes. A descrição da oxidação de AG em peroxissomos isolados de fígado de ratos, ocorrendo em paralelo à oxidação nas mitocôndrias, foi realizada por Lazarow e De Duve em 1976, que também descreveram o estímulo desta função pelo clofibrato.

A importância dos peroxissomos na síntese de glicerolipídios foi descrita em 1979 (HAJRA; BURKE; JONES, 1979) e a sua importância no metabolismo de AG de cadeia muito longa em 1982, pela observação do acúmulo destes em portadores da síndrome de Zellweger, uma doença causada pela ausência de peroxissomos em fígado, rins e cérebro (BROWN et al., 1982).

Desde a metade do século 20 é conhecida a resposta na proliferação destas organelas pelo tratamento com agentes hipolipidemiantes (HESS; STAUBLI; RIESS, 1965; SVOBODA e AZARNOFF, 1966). Entretanto, apenas no início da década de 1990 foi descrita a dependência da proliferação de peroxissomos pela ativação do que foi chamado "Receptor Ativado por Proliferadores de Peroxissomos" (PPAR) (ISSEMANN e GREEN, 1990).

Apesar das reações envolvidas na $\beta$-oxidação peroxissomal de AG serem muito parecidas com as da $\beta$-oxidação mitocondrial, existem muitas diferenças nesta via entre as duas organelas. Estas diferenças são primariamente relacionadas à maquinaria enzimática e o destino dos produtos gerados.

A principal diferença da $\beta$-oxidação peroxissomal em comparação à mitocondrial é o primeiro passo da via. Nos peroxissomos, esta reação não é catalisada pela acil CoA desidrogenase como nas mitocôndrias, mas por uma acil CoA oxidase, uma flavoproteína que transfere os elétrons derivados da desidrogenação do acil CoA diretamente para o oxigênio molecular. Esta reação não gera poder redutor (NADH) e não contribui para a geração de ATP, mas leva à produção de $\mathrm{H}_{2} \mathrm{O}_{2}$, que é então degradada pela enzima catalase, gerando $\mathrm{H}_{2} \mathrm{O}$ e 1/2 $\mathrm{O}_{2}$. Existem diferenças importantes entre as acil CoA oxidases de ratos e humanos. 
Em ratos, há duas isoformas de acil CoA oxidases em peroxissomos não hepáticos palmitoil CoA oxidase e pristanoil CoA oxidase. Nos hepatócitos, além destas duas isoformas, há ainda a colestanoil CoA oxidase, que reage exclusivamente com ésteres de intermediários do metabolismo de ácidos biliares (VAN VELDHOVEN et al., 1992). Em humanos, existem apenas duas isoformas de acil CoA oxidase; uma palmitoil CoA oxidase, com propriedades similares à correspondente encontrada em ratos e a acil CoA oxidase para grupos acil de cadeia ramificada, com especificidades similares às das pristanoil CoA oxidase e da colestanoil CoA oxidase encontradas em ratos (VANHOVE et al., 1993). Ainda com relação às diferenças no conjunto de enzimas, diferentemente das mitocôndrias, os peroxissomos contém enzimas bifuncionais que catalisam o segundo e terceiro passos da $\beta$-oxidação.

A especificidade do substrato é outra diferença importante entre a $\beta$-oxidação peroxissomal e mitocondrial. Peroxissomos contém enzimas que metabolizam PUFA e AG de cadeia muito longa, que não podem ser metabolizados nas mitocôndrias. A entrada dos substratos para a $\beta$-oxidação também se apresenta diferente entre as duas organelas. Enquanto o transporte de AG de cadeia longa nas mitocôndrias é exclusivamente mediado pelo sistema CPT, nos peroxissomos, este sistema não existe, mas a carnitina tem importância na exportação de acil CoA (WANDERS et al., 2001).

Durante muito tempo, aceitou-se a idéia de que as moléculas de acetil CoA geradas na $\beta$-oxidação peroxissomal são translocadas para a mitocôndria, onde seriam oxidadas pelo ciclo de Krebs, gerando equivalentes redutores, GTP e $\mathrm{CO}_{2}$. Entretanto, em estudos da $\beta$-oxidação em coração perfundido de ratos, não foi detectada transferência das moléculas de acetil CoA geradas nos peroxissomos para as mitocôndrias (BIAN et al., 2005). Este fato levanta a possibilidade destas moléculas serem empregadas na síntese de outros compostos. $\mathrm{O}$ uso do acetil CoA proveniente da $\beta$-oxidação na elongação de $A G$ foi descrito em células HepG2 (WONG et al., 2004). A Figura 2 ilustra as principais reações da oxidação de AG em uma célula hipotética sem peroxissomos e em uma outra célula onde a participação dos peroxissomos neste processo é expressiva. 


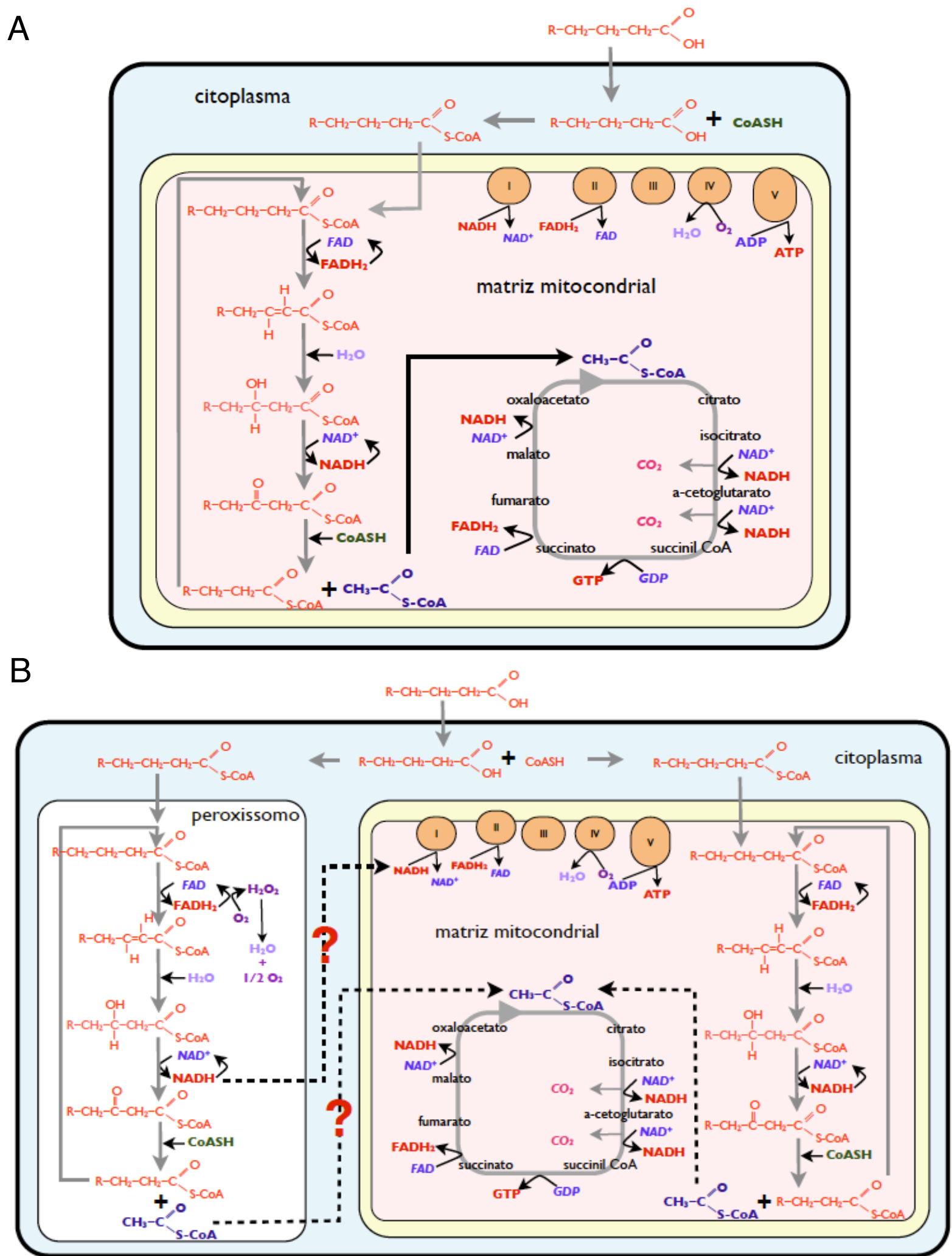

Figura 2 - Comparação entre a $\beta$-oxidação mitocondrial e a peroxissomal. Esquema representando a oxidação de acil-CoA em uma célula hipotética contendo apenas mitocôndrias (A) e em outra célula contendo peroxissomos e mitocôndrias (B). Importante atentar para 0 aumento da capacidade de oxidação de $A G$ em células contento peroxissomos e a ineficiência da $\beta$-oxidação peroxissomal em relação ao sistema mitocondrial - produção de $\mathrm{H}_{2} \mathrm{O}_{2}$ na primeira etapa da $\beta$-oxidação peroxissomal e a possibilidade de não haver translocação de NADH do peroxissomo para a mitocôndria. 


\subsection{Insulina}

A insulina é secretada pelas células $\beta$ pancreáticas após a elevação de glicose e nutrientes no plasma. As células secretoras de insulina são estimuladas pela elevação nas concentrações plasmáticas destes nutrientes por um mecanismo dependente da glicoquinase (MATSCHINSKY; GLASER; MAGNUSON, 1998). Observa-se então aumento da relação ATP/ADP causando fechamento dos canais de potássio dependentes de ATP, despolarização da membrana plasmática, influxo de $\mathrm{Ca}^{2+}$ e secreção de insulina (ASHCROFT e GRIBBLE, 1999).

Uma vez na circulação, a insulina desencadeia uma série de ações que culminam na redução da glicemia e aumento das reservas de metabólitos energéticos em diferentes tecidos (KROOK et al., 1997). Os principais efeitos da insulina são: aumento da síntese de glicogênio no músculo e fígado; redução da produção hepática de glicose; inibição da lipólise no tecido adiposo; inibição da proteólise e aumento da síntese protéica no músculo e estímulo da lipogênese em tecido adiposo e fígado. Além dos efeitos no metabolismo energético, a insulina também participa da regulação de outros processos, incluindo aumento da proliferação celular.

A ação da insulina inicia-se pela sua ligação à subunidade a do receptor, estimulando a atividade tirosina quinase intrínseca do receptor (BALLOTTI et al., 1989; KASUGA, 1993), que culmina em autofosforilação dos seus resíduos de tirosina. As subunidades $\beta$ fosforiladas permitem a ligação e fosforilação dos substratos do receptor de insulina-1, 2, 3 e 4 (IRS-1, 2, 3 e 4), dentre outros (PRONK et al., 1993).

Após fosforilado, o IRS-1 associa-se a várias proteínas incluindo a fosfatidilinositol 3-quinase (PI3-quinase) (BACKER et al., 1992; NYSTROM e QUON, 1999). A PI3-quinase ativada fosforila o fosfatidil-inositol (PI), resultando na formação de PI-3-fosfato, PI-3,4-difosfato e PI-3,4,5-trisfosfato, que permitem a propagação de sinais mediados por esta enzima (KAPELLER e CANTLEY, 1994). Um desses sinais é a ativação da quinase dependente de fosfoinositídeos-1 (PDK-1), que está envolvida na fosforilação e ativação da proteína quinase B (PKB ou Akt) (ALESSI et al., 1996) e das isoformas atípicas de proteína quinase $C$ (PKC) $\lambda$ e $\zeta$ (DONG et al., 1999). A Akt regula várias respostas da insulina (ALESSI e DOWNES, 1998; 
SUMMERS et al., 1999), como translocação do transportador da glicose - GluT4 à membrana plasmática (CHEATHAM et al., 1994; QUON et al., 1995), síntese protéica via p70 S6 quinase (p70s6K) (CHANG e TRAUGH, 1998), síntese de glicogênio, oxidação de glicose e atividade da lipase hormônio sensível (CARLSEN; CHRISTIANSEN; VINTEN, 1997; ASANO, 2000).

Outra via de sinalização da insulina é a cascata MAP quinase, que se inicia com a associação da Grb-2 ao Shc e, em menor grau, ao IRS-1, levando à formação do complexo Grb-2/Son of Sevenless (SoS) na membrana plasmática (LI et al., 1993; SKOLNIK et al., 1993) e conseqüente ativação da proteína c-Ras que, por sua vez, ativa a raf, primeiro elemento da cascata MAP quinase (BARON e VAN OBBERGHEN, 1995). Apesar de controversa, sugere-se a ativação desta cascata nos processos de síntese de glicogênio e translocação de GLUT-4 à membrana plasmática (YANO et al., 1993; SOMWAR et al., 2001; NYSTROM e QUON, 1999). O aumento na síntese de glicogênio deve-se também à ativação da fosfoproteína fosfatase-1 (PP-1) através da p90 S6 quinase ribossomal (p90rsk). A PP-1 é responsável pela desfosforilação e ativação da glicogênio sintase, resultando em aumento na síntese de glicogênio (YANO et al., 1993).

\subsection{Efeitos dos ácidos graxos nas respostas à insulina}

O diabetes mellitus tipo 2 e a obesidade apresentam resistência à insulina como característica comum (GORDON, 1960; BODEN, 1997). Nestas situações, a concentração plasmática de AG livres está elevada e o envolvimento desses metabólitos no desenvolvimento da resistência à insulina tem sido proposto. $O$ aumento prolongado da concentração de AG livres no plasma causa redução nas ações deste hormônio em vários tecidos, principalmente músculos estriados, fígado e adipócitos (RANDLE et al., 1963; HUNNICUTT et al., 1994; KIM et al., 1996; OAKES et al., 1997; BODEN, 2003). Entretanto, os mecanismos envolvidos ainda não são completamente conhecidos.

A influência nas ações da insulina varia de acordo com o tipo de AG. O ácido palmítico induz resistência ao hormônio, causando redução na captação de glicose em adipócitos (HUNNICUTT et al., 1994; VAN EPPS-FUNG et al., 1997) e músculo esquelético (THOMPSON et al., 2000; MONTELL et al., 2001; YU et al., 
2002). Este $A G$ causa também redução na síntese de glicogênio em adipócitos (VAN EPPS-FUNG et al., 1997) e tecido muscular (SCHMITZ-PEIFFER, 2000; THOMPSON et al., 2000).

Os efeitos dos AG dependem do tempo de exposição das células/tecido a estas moléculas. Quando o músculo sóleo é incubado por 1 hora na presença de ácido palmítico, observa-se diminuição da fosforilação de algumas proteínas da via de sinalização da insulina sem, entretanto, reduzir a captação de glicose ou a síntese de glicogênio (HIRABARA et al., 2007). Por outro lado, quando a exposição ocorre por período de tempo prolongado (infusão de lipídios por 5 horas), a inibição da fosforilação de proteínas da cascata de sinalização à insulina é mais pronunciada e ocorre diminuição na captação de glicose e síntese de glicogênio (YU et al., 2002).

Os PUFA, especialmente EPA e DHA, estão envolvidos no aumento da sensibilidade à ação da insulina (STORLIEN et al., 1991; LIU et al., 1994; CHICCO et al., 1996). PUFA n-3 na quantidade de $2,6 \mathrm{~g} / \mathrm{Kg}$ da dieta previnem a resistência à insulina induzida pela sacarose. Além disso, algumas alterações decorrentes da resistência à insulina são parcialmente revertidas e o transporte de glicose aumenta em ratos que recebera dietas com razão n-6:n-3 de 10 ou 5 . Estes efeitos não são observados quando a relação n-6:n-3 é superior a 10 (GHAFOORUNISSA et al., 2005). Holness et al. (2004) afirmam que PUFA n-3 revertem a hiperinsulinemia após a administração intravenosa de glicose em ratos que apresentam resistência à insulina induzida por AG saturados. A substituição de uma dieta hiperlipídica por outra rica em óleo de peixe melhora a ação da insulina em ratos, o que não ocorre quando uma dieta rica em ácido $\gamma$-linolênico (PUFA n-6) é utilizada. Este efeito do óleo de peixe na sensibilização à insulina é acompanhado de diminuição dos valores de triacilgliceróis e AG livres (NEFA) no plasma e do conteúdo de lipídios no fígado e músculo (SIMONCIKOVA et al., 2002).

Pighin et al. (2003) sugerem que o aumento de EPA e DHA nos fosfolipídios da membrana de músculo esquelético de ratos tratados com óleo de peixe relacionase com a reversão na baixa sensibilidade à insulina. Esta alteração na composição dos fosfolipídios pode influenciar a secreção e a ação da insulina através de alterações na fluidez da membrana e na função de segundos mensageiros. Outro possível mecanismo através do qual os PUFA n-3 previnem a resistência à insulina in vivo pode ser devido ao efeito hipolipidemiante do óleo de peixe (LOMBARDO e 
CHICCO, 2006). Nas próximas sessões serão discutidos os principais mecanismos de ação dos AG na modulação da resistência à insulina.

\subsubsection{Ciclo de Randle}

O ciclo AG-glicose ou ciclo de Randle refere-se ao aumento na disponibilidade de $A G$ e acúmulo de metabólitos na célula com diminuição na captação de glicose. O aumento no conteúdo de acetil-CoA proveniente de AG eleva a produção de citrato, que juntamente com a razão ATP/ADP elevada, inibe a atividade da fosfofrutoquinase, resultando em redução da atividade da via glicolítica. Como consequência, há aumento no conteúdo de glicose-6-fosfato, que passa a inibir a hexoquinase II, causando acúmulo de glicose intracelular e redução do seu transporte. Assim, os AG causam inibição da captação e utilização de glicose, resultando em resistência à insulina (RANDLE et al., 1963).

Contrariando o postulado do ciclo de Randle, verificou-se que os AG diminuem o conteúdo intracelular de glicose-6-fosfato e glicose antes da redução na captação de glicose estimulada pela insulina (THOMPSON et al., 2000; PERSEGHIN; PETERSEN; SHULMAN, 2003), sugerindo que outros mecanismos estão envolvidos na resistência ao hormônio induzida por esses metabólitos. Entretanto, Hirabara e colaboradores demonstraram que os efeitos dos AG na resposta à insulina podem ser explicados pelo ciclo de Randle quando a exposição aos AG é prolongada (HIRABARA et al., 2007).

\subsubsection{Inibição da sinalização à insulina}

O efeito dos AG sobre a via de sinalização da insulina foi estudado em vários tipos celulares. $O$ ácido palmítico inibe a atividade da MAP quinase em fibroblastos (USUl et al., 1997) e a fosforilação e a atividade da Akt em coração perfundido de rato e em células cardíacas HL-1 (SOLTYS et al., 2002). Além disso, o ácido palmítico reduz a fosforilação de pp185 (IRS-1 e -2) e em Akt de músculo esquelético de rato (THOMPSON et al., 2000; HIRABARA et al., 2003) e células musculares C2C12 (CHAVEZ e SUMMERS, 2003) e da GSK-3 em células 
musculares C2C12 (SCHMITZ-PEIFFER; CRAIG; BIDEN, 1999) e músculo esquelético de rato (HIRABARA et al., 2003).

Três vias podem estar envolvidas na inibição da sinalização à insulina por AG (BOLLAG et al., 1986; SCHMITZ-PEIFFER, 2000):

1) inibição da atividade da tirosina quinase do receptor da insulina. $O$ relato da inibição da atividade da PI-3 quinase associada ao IRS-1 após infusão de lipídios foi realizado por Dresner et al. em 1999. O mesmo grupo descreveu a relação deste efeito com a inibição da fosforilação em resíduos de tirosina do IRS-1 (YU et al., 2002). Estes resultados foram também descritos através de estudos in vitro, onde o ácido palmítico diminui a fosforilação em tirosina de IRS-1 e -2 em músculo sóleo isolado de ratos (HIRABARA et al., 2003).

2) ativação de tirosina fosfatases. A atividade e/ou a expressão de tirosinas fosfatases, tais como fosfatase LAR (leukocyte antigen-related), proteína-tirosina fosfatase 1B (PTP1B) e SHP2, estão elevadas em humanos e roedores obesos (MCGUIRE et al., 1991; AHMAD et al., 1997), sugerindo o envolvimento destas fosfatases no desenvolvimento da resistência à insulina induzida por AG.

3) ativação de serina e treonina quinases. Em muitos estudos foi verificado que os $A G$ aumentam a atividade de algumas isoformas de proteínas quinases $C$ (PKC) em músculo esquelético, tais como: PKC- $\varepsilon$ em ratos e PKC- $\theta$ e - $\delta$ em humanos e ratos (SCHMITZ-PEIFFER et al., 1997; GRIFFIN et al., 1999). PKC constituem um grupo de serina quinases com função importante em processos de crescimento, diferenciação, apoptose e secreção em diferentes tipos celulares. A ativação de $\mathrm{PKC}$ por AG pode estar relacionada à fosforilação elevada em resíduos de serina e treonina de IRS-1 (SHULMAN, 2000).

\subsubsection{Metabólitos lipídicos envolvidos na resistência à insulina}

Desde o final da década de 90, a função das ceramidas e diacilgliceróis (metabólitos originados a partir dos esfingolipídios de membrana, mono e tricilgliceróis) tem sido intensamente investigada e há fortes evidências de que estejam envolvidos no desenvolvimento da resistência à insulina.

As ceramidas são a base estrutural dos esfingolipídios, um grupo de lipídios polares que participam da formação da membrana plasmática, sendo composta por 
um grupo fosforilcolina, uma molécula de esfingosina e um AG de cadeia longa. Através da ação de esfingomielinases, que clivam o grupo fosforilcolina, formam-se as ceramidas. Pela ação de ceramidases, estas são decompostas em esfingosina e um AG livre (COX, 2005).

As ceramidas apresentam função importante como segundos mensageiros (GOMEZ-MUNOZ, 1998). A produção de ceramidas é aumentada por estímulos indutores de apoptose, diferenciação e citocinas inflamatórias (PFEILSCHIFTER e HUWILER, 2000). A presença de atividade de esfingomielinase neutra dependente de $\mathrm{Mg}^{2+}$ em músculo esquelético confirma que a sinalização via ceramidas é operante neste tecido.

Em células musculares em cultura tratadas com ácido palmítico, foi observado aumento expressivo na concentração de ceramidas e os efeitos do ácido palmítico foi mimetizado por um análogo destas (SCHMITZ-PEIFFER; CRAIG; BIDEN, 1999). O exercício físico induz diminuição no conteúdo de ceramidas no músculo por reduzir a atividade da esfingomielinase neutra dependente de $\mathrm{Mg}^{2+}$ e melhora a captação de 2-desoxi-glicose em diferentes tipos de músculo esquelético (DOBRZYN e GORSKI, 2002).

\subsubsection{A composição dos lipídios da membrana e a sinalização à insulina}

Vários grupos sugerem que a presença de PUFA n-3 na composição de fosfolipídios de membrana é importante para os efeitos desses AG na manutenção dos efeitos da insulina (STORLIEN et al., 1991; PIGHIN et al., 2003). Domínios específicos da membrana plasmática, conhecidos como lipid rafts e cavéolas podem concentrar receptores para diversos estímulos.

Cavéolas podem ser reconhecidas na maior parte da membrana citoplasmática por constituírem domínios morfologicamente identificáveis, altamente ricos em colesterol e esfingolipídeos e apresentarem relativa insolubilidade em detergentes como o Triton X-100 (FRANK et al., 2001; RAZANI e LISANTI, 2001). Entre os componentes estruturais das cavéolas, foram identificadas as caveolinas proteínas integrais de membrana ligadas ao colesterol que apresentam três isoformas (-1, -2 e -3). Cada caveolina apresenta um único padrão de distribuição, 
sendo a caveolina-3 a isoforma expressa em células de músculo esquelético, liso e cardíaco (TANG et al., 1996; SCHLEGEL et al., 1999).

Sabe-se que cavéolas e caveolinas estão envolvidas na transdução de sinais, inclusive o sinal da insulina (GUSTAVSSON et al., 1999; PARPAL et al., 2001). Várias moléculas de sinalização estão localizadas nestes domínios de membrana, como tirosinas quinases da família Src, membros das cascatas MAPK e ras e receptor de tirosinas quinases (NYSTROM et al., 1999; RAZANI; RUBIN; LISANTI, 1999; LEE et al., 2001). Além disso, Cohen et al., 2003 demonstraram que a caveolina-1 interage diretamente com o receptor da insulina, estabilizando e protegendo-o da degradação. Em cavéolas de células de ratos que receberam dietas com PUFA n-3 observa-se aumento de fosfolipídeos n-3 e redução de colesterol, alterando o microambiente destas (MA et al., 2004).

\subsection{5 Ácidos graxos e modulação da expressão gênica}

Ácidos graxos poliinsaturados reduzem a expressão da ACS, ACC, piruvato quinase, ATP-citrato liase, enzima málica, apoliproteína A1 e dessaturases $\Delta-5$ e -6 (SESSLER e NTAMBI, 1998; JUMP e CLARKE, 1999). O óleo de peixe, rico em PUFA n-3, ao contrário da trioleína, atenua a expressão das enzimas glicoquinase, piruvato quinase, enzima málica, AGS e proteína $\mathrm{S14}$ no fígado de ratos que receberam dieta rica em glicose. Em estudos in vitro com hepatócitos, foi demonstrado o efeito de PUFA das séries n-3 e n-6 na redução da expressão dos genes que codificam a AGS, piruvato quinase e proteína S-14 (JUMP e CLARKE, 1999). A adição de PUFA n-3 na dieta de ratos induz a síntese de enzimas responsáveis pela oxidação de AG nos peroxissomos hepáticos, como a $A C O$, enquanto suprimem a expressão de enzimas lipogênicas como a AGS (REN et al., 1997).

Em músculo esquelético, AG de cadeia longa aumentam a expressão das proteínas desacopladoras -2 e -3 (UCP-2 e -3), tioesterase-1 mitocondrial (MTE-1), CPT-1 e ACO (BRUN et al., 1999; TOTLAND et al., 2000; CHEVILLOTTE et al., 2001). 


\subsection{6 Ácidos graxos e receptores ativados por proliferados de peroxissomos}

Os receptores ativados por proliferadores de peroxissomos (PPAR) são fatores de transcrição que regulam a expressão de genes envolvidos principalmente no metabolismo de lipídios. Existem três isoformas de PPAR descritas: $a, \beta / \delta$ e $Y$ (SCHOONJANS; STAELS; AUWERX, 1996; KERSTEN; DESVERGNE; WAHLI, 2000; BISHOP-BAILEY e WRAY, 2003). O PPARa é expresso principalmente em tecidos com alta capacidade oxidativa de AG como fígado, coração, músculo esquelético e rins. O PPAR $\beta$ é expresso na maioria dos tecidos e em quantidades maiores que as demais isoformas. Já o PPARy é expresso principalmente no tecido adiposo, com menor expressão em outros tecidos (SCHOONJANS; STAELS; AUWERX, 1996; MICHALIK e WAHLI, 1999; KERSTEN; DESVERGNE; WAHLI, 2000; BISHOP-BAILEY e WRAY, 2003).

Entre os ligantes naturais dos PPAR estão os AG de cadeia longa e alguns derivados (GOTTLICHER; WIDMARK; GUSTAFSSON, 1992; KELLER et al., 1993). Chambrier e colaboradores relatam que EPA regula a transcrição de PPARY em adipócitos humanos in vivo. Uma vez ligados, o complexo PPAR-ligante heterodimeriza-se com o receptor do ácido 9-cis-retinóico $(R X R)$, ligado ao ácido 9cis-retinóico (GEARING et al., 1993; CHA et al., 2001). O heterodímero formado migra para o núcleo da célula onde se liga a regiões regulatórias de vários genesalvo conhecidas como elementos de resposta a PPAR (GEARING et al., 1993).

No fígado, a ativação do PPARa resulta em aumento no transporte e oxidação de AG. Isto é devido ao aumento na expressão de vários genes envolvidos no metabolismo de AG (MALLORDY et al., 1995; MASCARO et al., 1998). No tecido adiposo, a ativação do PPARy está relacionada com a diferenciação de adipócitos e aumento na captação e armazenamento de AG (AMRI; AILHAUD; GRIMALDI, 1994; ROSEN e SPIEGELMAN, 2001).

A indução da expressão dos genes das enzimas ACO e citocromo P450 4A2 por PUFA n-3 requer a ativação do PPARa. Por outro lado, a inibição da AGS e da proteína S14 mediada pelos PUFA n-3 não envolve esta isoforma de PPAR, sugerindo a participação de outros mecanismos (REN et al., 1997). Os efeitos dos PPAR no músculo esquelético, por outro lado, são menos conhecidos. Sugere-se que a ativação dos PPARa e $\beta$ neste tecido está envolvida no aumento da oxidação 
de AG. A ativação do PPARa no músculo esquelético resulta em aumento na expressão da MTE-1 (STAVINOHA et al., 2004), piruvato desidrogenase quinase (PDK), UCP e ativação do PPARß (CHEVILLOTTE et al., 2001).

\section{8 Ácidos graxos e obesidade}

A relação entre obesidade e ingestão de lipídios com a sensibilidade à insulina já foi bem caracterizada (LICHTENSTEIN e SCHWAB, 2000). Apesar disso, populações que mantém alta ingestão de peixes ricos em gordura como os esquimós da Groenlândia, apresentam menores índices de problemas cardiovasculares, dislipidemia, diabetes e resistência à insulina (MOURATOFF; CARROL; SCOTT, 1967; BANG; DYERBERG; SINCLAIR, 1980; KROMANN e GREEN, 1980; FESKENS; BOWLES; KROMHOUT, 1991; BJERREGAARD; PEDERSEN; MULVAD, 2000). Os PUFA n-3, presentes em altas concentrações na gordura dos peixes ingeridos pelos esquimós, podem protegê-los dos efeitos negativos associados à alta ingestão de gordura.

Em estudos com animais, PUFA n-3 são associados com redução dos depósitos de tecido adiposo, concentração de lipídios plasmáticos e tamanho dos adipócitos, ao contrário dos AG saturados (PARRISH; PATHY; ANGEL, 1990 PARRISH et al., 1991; OTTO; BALTZELL; WOOTEN, 1992; BELZUNG; RACLOT; GROSCOLAS, 1993; JONES; TOY; CHA, 1995). O EPA promove redução da massa corpórea, depósitos de tecido adiposo e dos distúrbios na homeostase glicêmica em camundongos tratados com dieta hiperlipídica e hipersacarídica (SATO et al., 2010). O DHA reduz a expressão de genes de enzimas lipogênicas e aumenta a expressão de genes responsáveis pela oxidação de lipídios no fígado, reduzindo o ganho de peso dos camundongos (SUN et al., 2010). A ausência de PUFA n-3 na dieta leva ao aumento da concentração de triacilgliceróis no fígado e de colesterol na circulação (PACHIKIAN et al., 2008).

Os ácidos oléico e palmitoléico são gerados após poucas modificações do ácido palmítico, produto direto da AGS. O ácido oléico induz acúmulo de triacilgliceróis em células 3T3-L1 (MADSEN; PETERSEN; KRISTIANSEN, 2005) e o palmitoléico é positivamente correlacionado com obesidade em humanos (OKADA et 
al., 2005; PAILLARD et al., 2008). Sato e colaboradores demonstraram que o EPA reduz a expressão da enzima responsável pela síntese dos ácidos palmitoléico e oléico - SCD-1, e a concentracão destes AG em partículas de VLDL do plasma de camundongos (SATO et al., 2010).

A redução na síntese de lipídios induzida pelos PUFA n-3, somada ao estímulo da oxidação de lipídios também induzida por estes AG contribui para a prevenção da obesidade e diabetes estimulada pelos PUFA n-3. Os mecanismos de ação dessas moléculas são alvos terapêuticos importantes para o tratamento dessas doenças. 


\section{Hipótese}

Os PUFA n-3 são reconhecido pelos seus efeitos antilipemiantes. Evidências experimentais e estudos populacionais mostram que estes AG induzem aumento da oxidação de lipídios. Por outro lado, a ingestão de quantidades excessivas de gordura de origem animal contribui para o desenvolvimento da resistência à insulina por interferir em vários processos envolvidos na resposta das células à este hormônio e na regulação da homeostase glicêmica.

Este conhecimento prévio nos levou a formular a hipótese de que camundongos tratados com dietas com alto teor de PUFA n-3 apresentariam oxidação mais intensa de $A G$, protegendo-se dos efeitos do acúmulo destes, mesmo quando ingeridos em quantidades excessivas. Por outro lado, animais tratados com dieta hiperlipídica com baixo teor de PUFA n-3 estariam predispostos a acumular $A G$, visto que a oxidação destas moléculas não estaria estimulada. 


\section{Objetivos}

\subsection{Objetivos gerais}

Comparar os efeitos de dietas com diferentes conteúdos de PUFA n-3, preparadas à base de óleo de peixe e banha de suínos na homeostase glicêmica em camundongos da linhagem Swiss.

\subsection{Objetivos específicos}

- Apontar diferenças induzidas pelo óleo de peixe e pela banha de suínos no acúmulo de tecido adiposo e ganho de peso;

- Investigar o metabolismo de lipídios em resposta às diferentes intervenções dietéticas e relacionar as alterações deste com aquelas observadas no metabolismo de carboidratos;

- Estudar os mecanismos de ação através dos quais os PUFA n-3 modulam o metabolismo da glicose. 


\section{Materiais e métodos}

\subsection{Modelo animal}

Camundongos machos da linhagem Swiss procedentes do Biotério Central da Universidade de Campinas (Campinas, SP) e do Animal Resources Center (Perth, Australia) foram mantidos em um ciclo claro/escuro de 12/12h com livre acesso à água e ração. Foram tratados 3 lotes de animais para a obtenção dos dados aqui apresentados. Em todas as ocasiões, os tratamentos somente foram iniciados quando os camundongos apresentavam a idade de 8 - 10 semanas.

Todos os experimentos foram aprovados pelo Comitê de Ética em Experimentação Animal do Instituto de Ciências Biomédicas da Universidade de São Paulo e do Garvan Institute/St. Vincent's Hospital e conduzidos seguindo protocolos experimentais aprovados no Brasil e Austrália.

A resistência à obesidade induzida pela dieta é uma das características da linhagem de camundongos Swiss (WEST et al., 1992). O uso desta linhagem de camundongos reduz a influência da obesidade nos efeitos observados, que passam a ser mais dependentes da dieta.

\subsection{Desenho experimental}

Os camundongos foram divididos em cinco grupos alimentados com dietas contendo diferentes quantidades de lipídios por 8 semanas. $O$ grupo referência (chow) recebeu dieta padrão para roedores. Dois grupos foram alimentados com dietas contendo $4 \%$ e $40 \%$ de lipídios (em massa), consistindo de $90 \%$ de óleo de peixe e $10 \%$ óleo de soja. Estes grupos foram denominados NFO e HFO, respectivamente. Os outros dois grupos foram alimentados com dietas contendo $4 \%$ e $40 \%$ de lipídios cuja composição foi $90 \%$ banha de suínos e $10 \%$ de óleo de soja e denominados NL e HL. Os teores de lipídios totais foram selecionados de forma que duas dietas preparadas à base de banha e óleo de peixe apresentassem teor de lipídios semelhante ao da dieta padrão para animais de laboratório, enquanto as duas outras dietas fossem preparadas com teores muito maiores de lipídios 
(quantidade $10 \times$ maior em massa). A composição das dietas baseou-se na formulação das dietas D12450B e D12492 da empresa Research Diets (Research Diets Inc., New Brunswick, USA). O perfil de AG e a composição das dietas estão apresentados nas Tabelas 2 e 3.

Este desenho experimental permitiu a comparação dos efeitos das dietas contendo óleo de peixe com aquelas contendo banha, quando o conteúdo de lipídios totais foi baixo ou alto. A banha de suínos foi utilizada como controle em relação ao óleo de peixe por seu baixo conteúdo de PUFA n-3. O grupo referência foi alimentado com dieta padrão para roedores mantidos em biotérios por esta ser a condição considerada normal. Apesar disso, devido ao fato desta dieta ser preparada com ingredientes muito diferentes daqueles utilizados para os grupos NFO, HFO, NL e HL, as comparações entre os últimos e o grupo chow devem ser realizadas com cautela. Fatores como palatabilidade, digestibilidade, conteúdo de açúcares simples, fibras e outros podem ter efeito significativo no metabolismo de macronutrientes.

Tabela 2 - Ingredientes e conteúdo energético das dietas. Alguns ingredientes da dieta do grupo Chow foram estimados de acordo com as informações constantes no website do fabricante. * - valores referentes à carboidratos, proteínas, lipídios e fibras totais, não necessariamente da mesma fonte utilizada para o preparo das dietas dos demais grupos. Chow - grupo controle, NFO - grupo tratado com dieta normolipídica à base de óleo de peixe, HFO - grupo tratado com dieta hiperlipídica à base de óleo de peixe, NL - grupo tratado com dieta normolipídica à base de banha, HL - grupo tratado com dieta hiperlipídica à base de banha.

\begin{tabular}{l|c|c|c|c|c}
\hline \multicolumn{1}{c|}{ Ingredientes $(\mathbf{g} / \mathbf{K g})$} & Chow & NFO & HFO & NL & HL \\
\hline amido & \multirow{2}{*}{$533^{*}$} & 466 & 116 & 466 & 116 \\
\cline { 1 - 4 } amido dextrinizado & & 155 & 132 & 155 & 132 \\
\cline { 3 - 6 } sacarose & $220 *$ & 140 & 200 & 140 & 200 \\
\hline caseína & $45^{*}$ & 4 & 35 & 4 & 35 \\
\hline óleo de soja & & 36 & 315 & 36 & 315 \\
\hline óleo de peixe (NFO e HFO) ou banha (NL e HL) & & 50 & 50 & 50 & 50 \\
\hline celulose & $80^{*}$ & 50 & 100 & 100 \\
\hline mistura de minerais & 122 & 35 & 35 & 35 & 35 \\
\hline mistura de vitaminas & 10 & 10 & 10 & 10 & 10 \\
\hline cistina & & 2 & 3 & 2 & 3 \\
\hline bitartato de colina & & 3 & 3 & 3 & 3 \\
\hline energia (KJ /g) determinado por calorimetria & 15,2 & 10,6 & 22,5 & 10,6 & 22,5 \\
\hline
\end{tabular}


Tabela 3 - Composição de ácidos graxos das dietas. Dados expressos como percentagem de participação nos lipídios totais extraídos das dietas ou calculados a partir da formulação do componente lipídico das mesmas. Apesar do conteúdo lipídico diferente (ver Tab. 1), os grupos NFO e HFO apresentam a mesma composição percentual em ácidos graxos, assim como os grupos NL e HL. Chow - grupo controle, NFO - grupo tratado com dieta normolipídica à base de óleo de peixe, HFO - grupo tratado com dieta hiperlipídica à base de óleo de peixe, NL - grupo tratado com dieta normolipídica à base de banha, HL - grupo tratado com dieta hiperlipídica à base de banha.

\begin{tabular}{|c|c|c|c|}
\hline Ácidos graxos & Chow & NFO e HFO & NL e HL \\
\hline ácido mirístico (14:0) & - & 7,7 & 1,1 \\
\hline ácido palmítico (16:0) & 15,6 & 19,4 & 24,1 \\
\hline ácido palmitoléico (16:1) & - & 9,4 & 1,6 \\
\hline ácido esteárico (18:0) & 4,2 & 3,5 & 13,8 \\
\hline ácido oléico (18:1) & 27,1 & 17,4 & 39,2 \\
\hline ácido linoléico (18:2n6) & 49,0 & 9,2 & 18,0 \\
\hline ácido linolênico (18:3n3) & 2,9 & 3,1 & 0,97 \\
\hline ácido araquidônico (20:4n6) & - & 17,7 & - \\
\hline EPA $(20: 5 n 3)$ & - & 1,8 & - \\
\hline $\mathrm{DHA}(22: 6 n 3)$ & - & 10,8 & - \\
\hline$\sum$ saturados & 19,8 & 30,6 & 39,0 \\
\hline$\sum$ PUFA n-6 & 49,0 & 26,9 & 18,0 \\
\hline$\sum$ PUFA n-3 & 2,9 & 15,6 & 0,97 \\
\hline$n-6 / n-3$ & 17,1 & 1,7 & 18,5 \\
\hline
\end{tabular}

\subsection{Balanço energético e composição corporal}

A massa corpórea dos camundongos foi avaliada semanalmente em balança semi analítica.

A ingestão alimentar foi monitorada durante a segunda, quinta e sétima semanas do experimento, mantendo-se os camundongos individualmente nas caixas. Nestes períodos, foram instaladas nas caixas plataformas preparadas com malha de aço inoxidável a fim de impedir o contado do camundongo com o fundo da 
caixa. O fundo da caixa foi forrado com papel absorvente, de modo que os restos de dieta e as fezes não permaneciam em contato com a urina que era imediatamente absorvida. Dessa forma também foi minimizada a contaminação das fezes com os restos de alimentos.

O teor de umidade das dietas frescas (antes de serem colocadas nas caixas) e dos restos de alimento (dieta retirada das caixas) foi determinado por método gravimétrico. A ingestão alimentar foi quantificada pela seguinte fórmula: (dieta fresca colocada na caixa (g) - umidade da dieta fresca (g)) - (restos de alimetos retirados da caixa após $24 \mathrm{~h}(\mathrm{~g})$ - umidade dos restos de alimento (g)). Diariamente, as fezes foram coletadas e congeladas. Após o processo de liofilização das fezes, foi determinada a excreção fecal diária, expressa em gramas.

O teor de energia das dietas e das amostras de fezes foi determinado utilizando-se um calorímetro de bomba (modelo C5000, Ika, Alemanha). Conhecendo-se a densidade energética das dietas e das fezes, a ingestão alimentar e produção fecal diárias, foi possível calcular a absorção energética diária pela seguinte fórmula: (ingestão alimentar diária $(\mathrm{g})$ * teor energético das dietas $(\mathrm{J} / \mathrm{g})$ ) (excreção fecal diária (g) * teor energético das fezes $(\mathrm{J} / \mathrm{g})$ ). Finalmente, conhecendose o ganho de massa corpórea durante o período de tratamento e a quantidade de energia absorvida durante o mesmo período, pode-se calcular a eficiência energética dos camundongos. Este índice é o quociente do ganho de massa corpórea (g) pela absorção energética acumulada no período (KJ).

A composição corporal (quantidade de massa gorda e massa magra) foi avaliada através da medida de radioabsorciometria de feixes duplos (DEXA), utilizando-se um Lunar PIXImus2 mouse densitometer (GE Healthcare, Madison, EUA).

\subsection{Determinação do gasto energético}

A taxa de consumo de oxigênio $\left(\mathrm{VO}_{2}\right)$ dos camundongos foi mensurada individualmente através de calorimetria indireta (Oxymax, Columbus Intruments, Columbus, EUA) como descrito previamente (TURNER et al., 2007). Os registros foram realizados após um período de duas horas de adaptação dos animais nas 
câmaras em intervalos de 27 min, durante $24 \mathrm{~h}$. A temperatura ambiente foi mantida a $22{ }^{\circ} \mathrm{C}$ durante as determinações e os animais tiveram acesso livre à água e ração.

\subsection{GTT e ITT}

O teste de tolerância à glicose (GTT) foi realizado em camundongos acordados mantidos em jejum por 7 horas, às $15 \mathrm{~h}$, na oitava semana do tratamento, utilizandose $2 \mathrm{~g} / \mathrm{Kg}$ de glicose injetada intraperitonealmente. Amostras de sangue foram coletadas através de um pequeno corte na extremidade da cauda e a concentração de glicose foi avaliada com um glicosímetro (Accu-check, Roche) nos períodos de 0 , $15,30,45,60$ e $90 \mathrm{~min}$.

O teste de tolerância à insulina (ITT) foi realizado na sétima semana de tratamento em camundongos acordados mantidos em jejum por 7 horas às $15 \mathrm{~h}$, da mesma forma que para o GTT. A insulina foi injetada intraperitonealmente utilizandose a dose de $0,75 \mathrm{mUl} / \mathrm{g}$ de peso. A glicemia foi monitorada nos períodos de 0,10 , 20, 30, 40 e 60 minutos. Amostras de plasma foram coletadas de camundongos em jejum no dia do sacrifício para a determinação de insulina. As concentrações de insulina foram determinadas por radioimunoensaio (Linco Research, St. Charles, $\mathrm{MO})$.

\subsection{Captação de glicose e síntese de glicogênio em músculo sóleo}

As avaliações da captação de 2-desoxi-glicose e incorporação de glicose em glicogênio no músculo sóleo incubado foram realizadas de acordo com uma adaptação do método descrito por Cuendet et al. (1976). Em resumo, músculos sóleos foram isolados dos camundongos, presos em grampos de aço inoxidável pelos tendões de origem e inserção, para preservar sua forma anatômica, e préincubados em tampão Krebs-Ringer, $\mathrm{pH} 7,4$, contendo 5,6 mM de glicose, a $31^{\circ} \mathrm{C}$, por 45 min. Após a pré-incubação, os músculos foram transferidos para outros frascos contendo o mesmo tampão na presença ou ausência de $300 \mu \mathrm{UI} / \mathrm{mL}$ de insulina, contendo 0,2 $\mu \mathrm{Ci}$ de $\mathrm{D}$-[U-14 C]glicose e $0.2 \mu \mathrm{Ci}$ de 2-desoxi-D-[2,6-3H] glicose. Após incubação por 1 hora, os músculos foram lavados em solução salina gelada, secos em papel de filtro, pesados e digeridos em hidróxido de potássio a 1 
M. O glicogênio foi precipitado com $66 \%$ de etanol, lavado com água destilada e dissolvido em $400 \mu \mathrm{L}$ de água destilada. Alíquotas do músculo digerido e do glicogênio extraído foram usadas para se determinar a contagem de ${ }^{14} \mathrm{C}$ e ${ }^{3} \mathrm{H}$, para expressar a captação de 2-desoxi-glicose e a incorporação de glicose em glicogênio.

\subsection{Determinação de metabólitos lipídicos}

As concentrações plasmáticas de colesterol, triacilgliceróis e $A G$ não esterificados (NEFA) foram determinadas utilizando-se kits enzimáticos (Quibasa, Belo Horizonte, Brasil e Wako Pure Chemicals, Osaka, Japão), de acordo com as instruções dos fabricantes.

O conteúdo de triacilgliceróis do fígado e músculo gastrocnêmio foi determinado utilizando-se um kit enzimático, após extração dos lipídios totais, de acordo com o protocolo de Folch et al. (1957) e solubilização em etanol.

O conteúdo de diacilgliceróis foi determinado por cromatografia em camada delgada (TLC), após extração dos lipídios e solubilização em n-hexano. A TLC foi realizada de acordo com o método de Nakamura e Handa (1984).

A determinação da composição de AG no plasma, fígado e tecido adiposo foi realizada através da transmetilação dos lipídios totais, gerando ésteres metílicos de AG, de acordo com uma adaptação do método de Hartman e Lago (1973). Os ésteres metílicos de AG foram analisados utilizando-se um cromatógrafo Shimadzu 17A (Shimadzu Co, Japão) equipado com um detector de ionização de chama (FID) e uma coluna capilar de sílica fundida SP 2340 Supelco (60 m x 0,25 mm x 0,2 mm) (Supelco Co., EUA). A identificação dos AG foi realizada pela comparação dos tempos de retenção dos picos dos cromatogramas das amostras com aqueles do padrão FAME Mix 37 Components Supelco (Supelco Co., EUA).

\subsection{Oxidação do ácido palmítico}

A oxidação do ácido palmítico foi avaliada em homogenatos de fígado e músculo tibialis de acordo com método descrito por Kim et al. (2000). Os tecidos foram homogeneizados em 19 volumes de tampão (sacarose $250 \mathrm{mM}$, Tris- $\mathrm{HCl} 10$ $\mathrm{mM}$ e EDTA $1 \mathrm{mM}, \mathrm{pH} 7,4)$. Cinquenta $\mu \mathrm{L}$ do homogenato do tecido foram incubados 
com $450 \mu \mathrm{L}$ da mistura de reação (sacarose $100 \mathrm{mM}, \mathrm{KCl} 80 \mathrm{mM}$, Tris- $\mathrm{HCl} 10 \mathrm{mM}$, $\mathrm{KH}_{2} \mathrm{PO}_{4} 5 \mathrm{mM}, \mathrm{MgCl}_{2} 1 \mathrm{mM}$, malato $2 \mathrm{mM}$, ATP $2 \mathrm{mM}$, ditiotreitol $1 \mathrm{mM}$, EDTA 0,2 mM e BSA sem AG 0,3\%). O tampão continha 0,2 M de palmitato e 0,2 $\mu \mathrm{Ci}$ de [1-14C]-palmitato, $2 \mathrm{mM}$ de L-carnitina e 0,05 mM de coenzima A. Após 90 minutos de incubação a $30{ }^{\circ} \mathrm{C}$, a reação foi interrompida pela adição de $100 \mu \mathrm{L}$ de ácido perclórico a $1 \mathrm{M}$. O CO 2 produzido a partir do [1-14C]-palmitato foi coletado em 100 $\mu \mathrm{L}$ de hidróxido de sódio a $1 \mathrm{M}$. A contagem de ${ }^{14} \mathrm{C}$ presente no sobrenadante do meio acidificado foi utilizada para calcular a concentração de metabólitos do ácido palmítico gerados durante a $\beta$-oxidação deste $A G$, referidos como metabólitos solúveis em ácido (ASM).

\subsection{Avaliação da atividade das enzimas da $\beta$-oxidação e ciclo de Krebs}

O músculo gastrocnêmio e o fígado foram homogeneizados (1:19 - peso/vol) em um tampão composto de Tris-HCl 50 mM, EDTA 1 mM e Triton X-100 0,1%, pH 7,2. As amostras foram submetidas a três ciclos de congelamento e descongelamento. A atividade das enzimas acil CoA oxidase (ACO), citrato sintase (CS), $\beta$-hydroxyacyl CoA desidrogenase ( $\beta$-HAD), desidrogenase de acil-CoA de cadeia média (MCAD) e succinato desidrogenase (SDH) foi determinada a $30{ }^{\circ} \mathrm{C}$ conforme descrito em Turner et al. (2007). As reações foram monitoradas por espectrofotometria utilizando um leitor de placas (Spectra Max 250 - Molecular Devices, Sunnyvale, EUA).

\subsection{Western Blotting}

Fígados dos animais foram homogeneizados em tampão RIPA (Tris- $\mathrm{HCl} 65$ $\mathrm{mM}, \mathrm{NaCl} 150 \mathrm{mM}$, nonidet NP-40 $1 \%$, desoxicolato de sódio 0,5\% e dodecil sulfato de sódio 0,1\%, $\mathrm{pH} 7,4)$ adicionado de inibidores de proteases e fosfatases $(10 \mu \mathrm{g} /$ $\mathrm{mL}$ de leupeptina, $\mathrm{Na}_{3} \mathrm{VO}_{4} 1 \mathrm{mM}$ e NaF $10 \mathrm{mM}$ ) e solubilizado por 1 hora a $4{ }^{\circ} \mathrm{C}$. Os homogenatos (20 $\mathrm{\mu g}$ de proteína) foram resolvidos em SDS-PAGE, transferidos para membranas de PVDF e estas incubadas com anticorpos contra a isoforma hepática 
da CPT-1 (Alpha Diagnostics International, San Antonio, TX), subunidade 1 da citocromo oxidase - complexo IV da cadeia transportadora de elétrons (CTE) da membrana mitocodrial interna (Invitrogen, Victoria, Australia), um coquetel de anticorpos que reconhece as subunidades V, III e II da cadeia transportadora de elétrons (CTE) (Mitomix, Mitosciences, Eugene, OR), PMP-70 (ABCam), ACS (cedido pelo Dr. Greg Cooney), ACC (Cell Signaling), ACC fosforilada (Cell Signaling), AGS e PEPCK. O conteúdo das proteínas foi normalizado pelo conteúdo da Pan 14-3-3, uma proteína abundante, de 30 KD. As bandas visualizadas em filme fotossensível foram quantificadas por densitometria após reação de peroxidase acoplada a um anticorpo que reconhece a lgG do anticorpo primário.

\subsection{Experimento com o agonista de PPAR Wy-14,643}

Para confirmar o envolvimento do PPAR nos efeitos observados pelo tratamento com óleo de peixe, um grupo de camundongos machos da linhagem Swiss foi tratado com Wy-14,643, um agonista de PPAR que induz proliferação de peroxissomos.

Camundongos alimentados com a dieta do grupo Chow foram tratados com a droga por gavagem durante 7 dias com uma dose diária de $10 \mathrm{mg} / \mathrm{Kg}$ de peso corpóreo. Um segundo grupo de camundongos (Controle) recebeu água por gavagem durante o mesmo período. Os hepatócitos foram isolados no fim do período de tratamento, de acordo com o método de Berry e Friend (1969) e a oxidação de palmitato foi avaliada em hepatócitos recém-isolados, de maneira similar ao procedimento descrito acima para oxidação do palmitato em homogenatos de fígado.

\subsection{Análise estatística}

Os dados estão apresentados como média \pm erro padrão da média. Dependendo da natureza dos dados, teste $\mathrm{T}$ de Student, análise de variância (ANOVA) com uma variável seguida do teste de Tukey ou ANOVA com duas variáveis seguida do teste de Bonferroni foram utilizados para identificar diferenças 
estatisticamente significativas entre os grupos. Diferenças com valores de $P<0,05$ foram consideradas estatisticamente significantes. 


\section{Resultados}

\subsection{Balanço energético}

A eficiência da absorção de energia foi similar entre os grupos. Apenas o grupo chow apresentou-se menos eficiente quanto à absorção de energia. Este efeito deve ser devida às diferenças na composição da dieta deste grupo, que não foi preparada a partir de ingredientes isolados como nas demais (Figura 3A). A menor eficiência na absorção de nutrientes do grupo chow foi compensada por maior ingestão alimentar, de forma que este apresentou valores de absorção energética semelhantes aos dos grupos NFO, HFO e NL. Apenas o grupo HL apresentou menor absorção de energia, devido à menor ingestão energética e não devido à deficiências na absorção dos nutrientes (Figura 3B).

Apesar de ter apresentado a menor absorção de energia, o grupo $\mathrm{HL}$ foi o que apresentou índice de eficiência energética significativamente maior. Este dado reflete a conversão da energia absorvida em massa corpórea. Em outras palavras, são mais eficientes energeticamente os animais que conseguem maior incremento na massa corpórea com valores mais baixos de absorção energética. Os grupos chow e HFO foram os que apresentaram a menor eficiência energética (Figura 3C). Esta diferença, que poderia indicar taxa metabólica basal elevada será discutida em maiores detalhes adiante, após a apresentação de outros dados relativos ao metabolismo energético. 

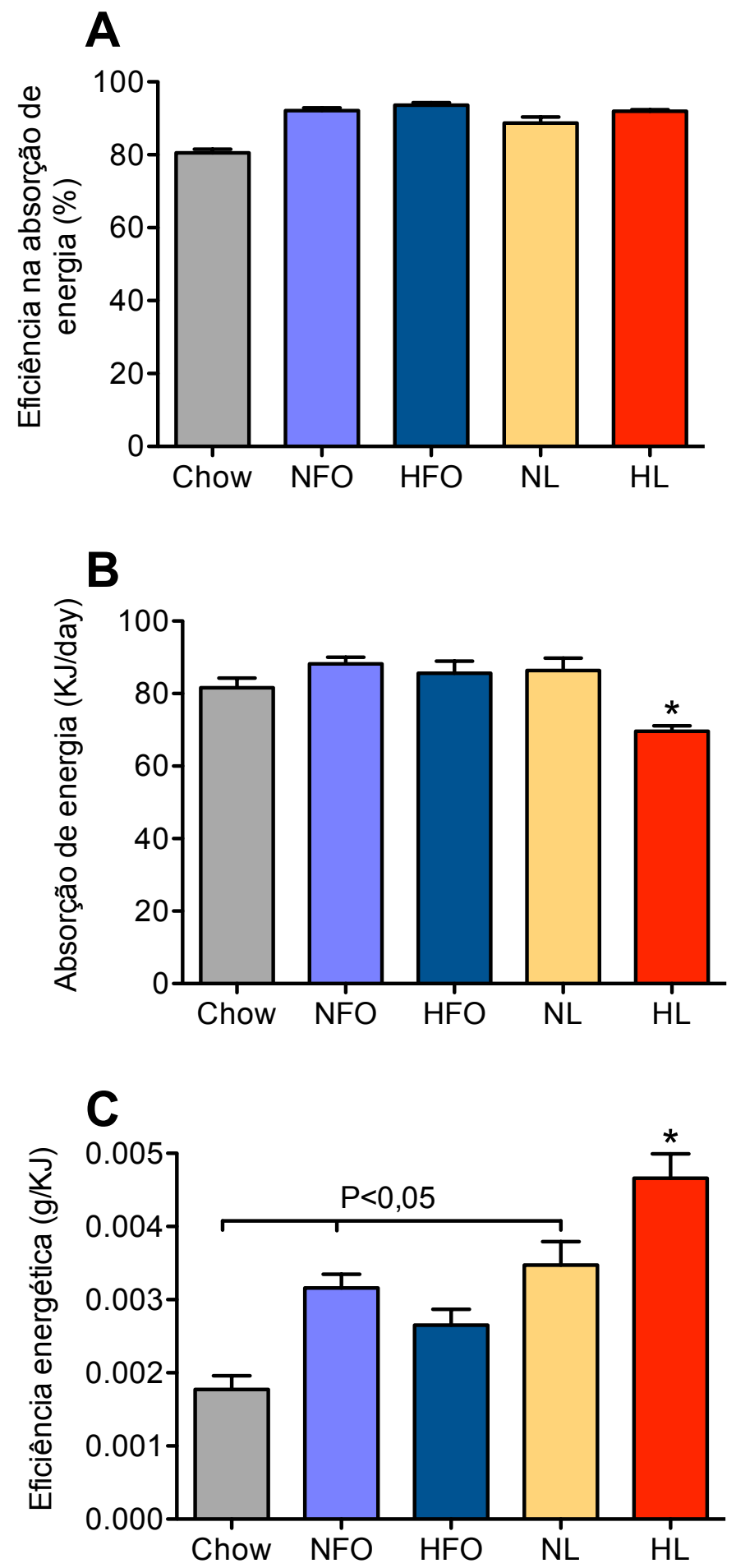

Figura 3. Balanço energético. A - Eficiência da absorção de energia (percentagem em relação à ingestão energética). B - Média da absorção diária de energia. C - Eficiência energética (energia ingerida durante o tratamento (KJ) / massa corpórea acumulada (g). Chow grupo controle, NFO - grupo tratado com dieta normolipídica à base de óleo de peixe, HFO - grupo tratado com dieta hiperlipídica à base de óleo de peixe, NL - grupo tratado com dieta normolipídica à base de banha, $\mathrm{HL}$ - grupo tratado com dieta hiperlipídica à base de banha. (ANOVA com uma variável, seguido do teste de Tukey). 


\subsection{Composição corporal e ingestão energética}

Os grupos HFO e chow apresentaram massa corpórea final diminuída em relação aos tratados com dietas à base de banha, apesar do alto teor de lipídios na dieta do grupo HFO (Figura 4).

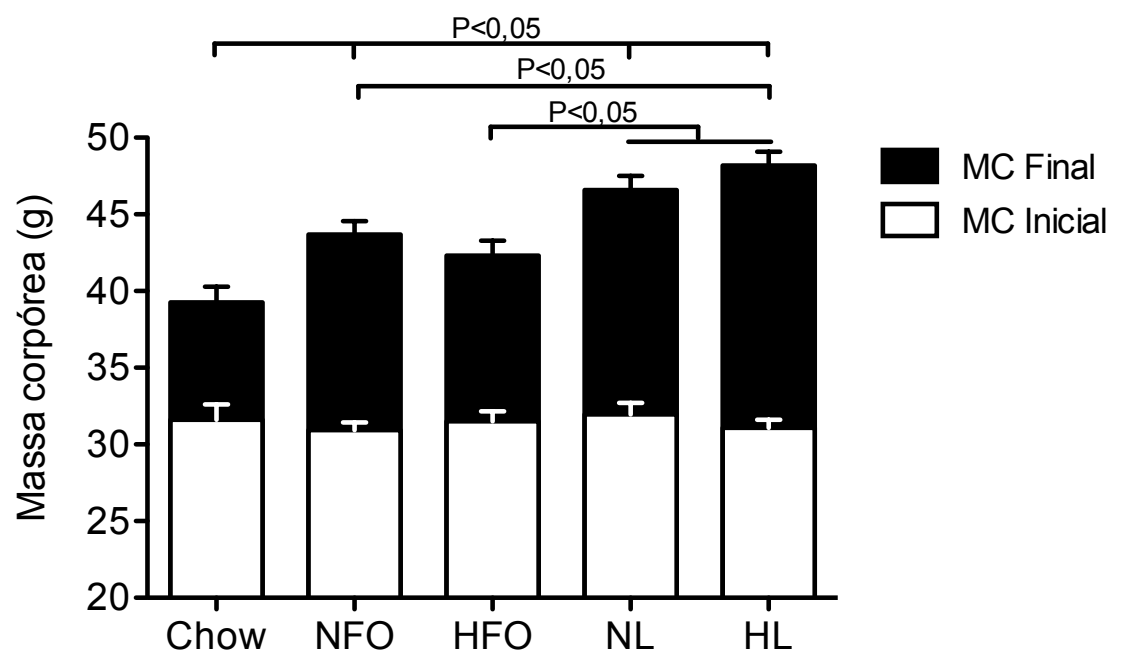

Figura 4. Massa corpórea. Comparação entre o peso inicial e final dos camundongos, após 8 semanas de tratamento. Chow - grupo controle, NFO - grupo tratado com dieta normolipídica à base de óleo de peixe, HFO - grupo tratado com dieta hiperlipídica à base de óleo de peixe, NL - grupo tratado com dieta normolipídica à base de banha, HL - grupo tratado com dieta hiperlipídica à base de banha. (ANOVA com uma variável, seguida do teste de Tukey. $n=20$ ).

$\mathrm{O}$ grupo $\mathrm{HL}$ apresentou peso corporal significativamente aumentado em relação ao grupo chow após a terceira semana de tratamento e em relação aos grupos tratados com óleo de peixe após a sexta semana (Figura 5). Os grupos chow e HFO foram também diferentes do grupo NL após a quarta e sétima semanas, respectivamente. 


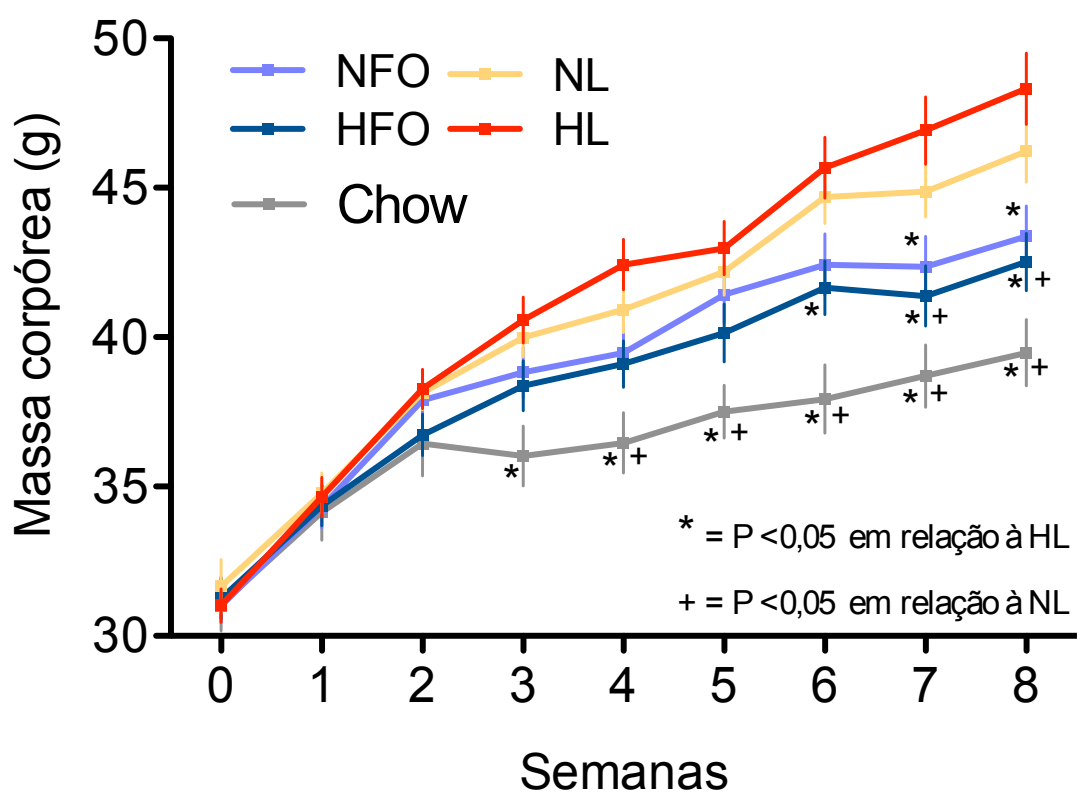

Figura 5. Curva de ganho de massa corporal. Evolução da massa corporal dos animais ao longo do tratamento. Chow - grupo controle, NFO - grupo tratado com dieta normolipídica à base de óleo de peixe, HFO - grupo tratado com dieta hiperlipídica à base de óleo de peixe, NL - grupo tratado com dieta normolipídica à base de banha, HL - grupo tratado com dieta hiperlipídica à base de banha. (ANOVA com duas variáveis seguida do teste de Bonferroni. $\mathrm{n}=20$ ).

O grupo Chow apresentou os menores depósitos de gordura, ao contrário do grupo HL, onde os maiores depósitos desse tecido foram encontrados. É importante notar que, apesar de ingerir uma dieta com o mesmo teor lipídico que o grupo HL (40 $\%)$, o grupo HFO apresentou o mesmo peso de tecido adiposo retroperitoneal (TAR) e tecido adiposo epididimal (TAE) que o grupo NFO, tratado com uma dieta com teor de gordura 10 vezes menor. No caso do tecido adiposo inguinal (TAI), um depósito de tecido adiposo subcutâneo, a deposição de gordura no grupo HFO foi similar à do grupo chow. Também merece destaque o fato de que o grupo NL apresentou maior deposição de TAE e TAR que o grupo NFO, embora ambos tenham o mesmo teor de gordura na dieta e valores similares para TAE e TAI que o grupo HL. Estas observações e o fato de que o grupo NFO apresentou o mesmo peso para TAI que o grupo $\mathrm{HL}$ evidenciam o menor acúmulo de gordura observado na linhagem de camundongos Swiss em resposta à dieta hiperlipídica. Assim, pelo menos nesta linhagem de camundongos, o tipo de lipídios da dieta é mais importante que sua quantidade na determinação da obesidade (Figura 6). 

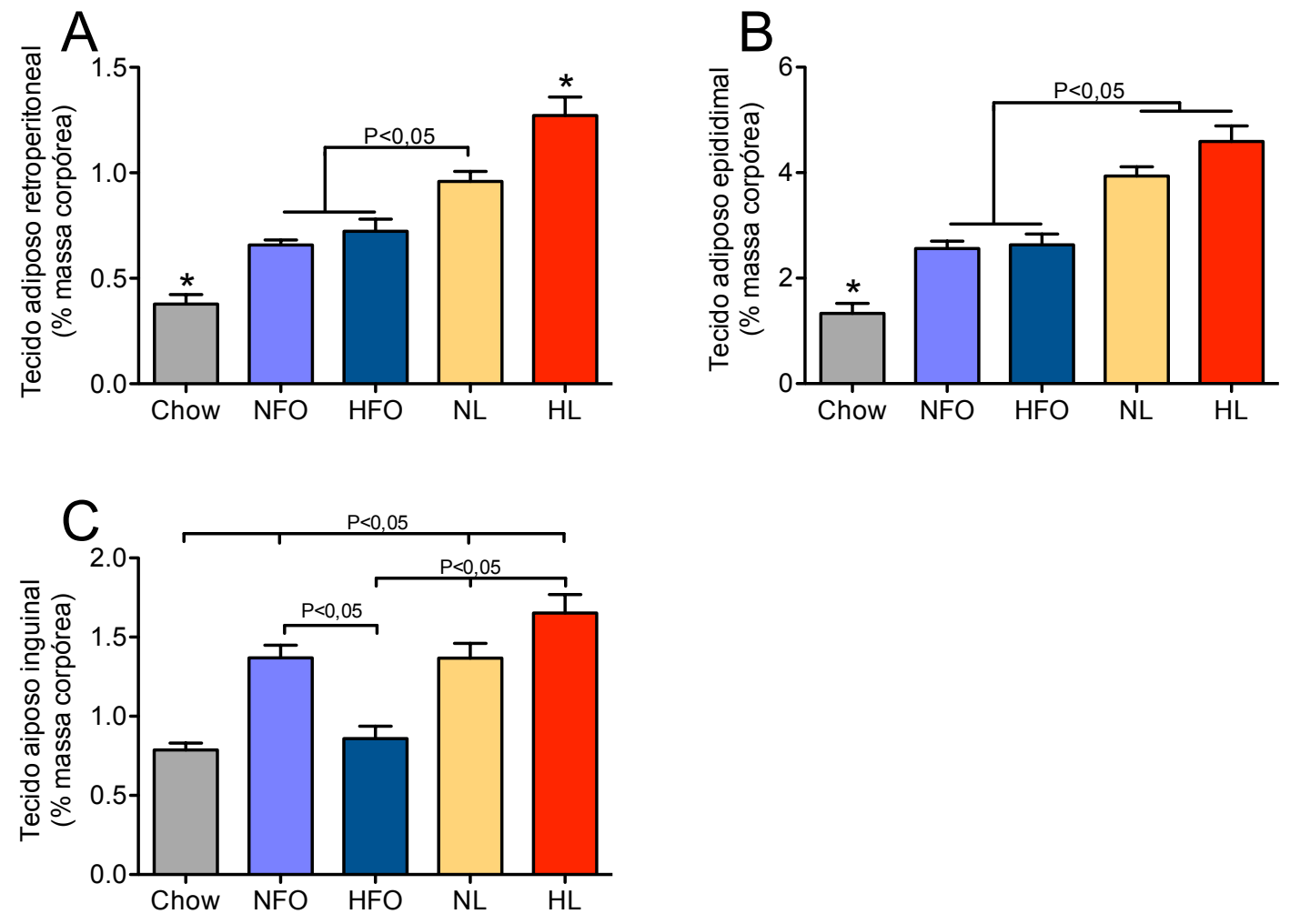

Figura 6. Depósitos de tecido adiposo. A - Peso do tecido adiposo retroperitoneal em comparação percentual à massa corpórea. $\mathrm{B}$ - Peso do tecido adiposo epididimal em comparação percentual à massa corpórea. C - Peso do tecido adiposo inguinal em comparação percentual à massa corpórea. Chow - grupo controle, NFO - grupo tratado com dieta normolipídica à base de óleo de peixe, HFO - grupo tratado com dieta hiperlipídica à base de óleo de peixe, NL - grupo tratado com dieta normolipídica à base de banha, $\mathrm{HL}$ - grupo tratado com dieta hiperlipídica à base de banha. $\left({ }^{*}=P<0,05\right.$ em relação aos demais grupos. ANOVA com uma variável, seguida do teste de Tukey. A e B - $n=20, C-n=14$ ).

A quantidade de massa gorda corpórea apresentou a mesma resposta aos tratamentos que a quantidade de TAI. O grupo HFO apresentou quantidades de gordura corporal similares ao grupo chow, enquanto que os grupos NL e NFO apresentaram o mesmo teor de gordura corporal que o grupo HL. Não foram detectadas diferenças na quantidade de massa magra (Figura 7). 

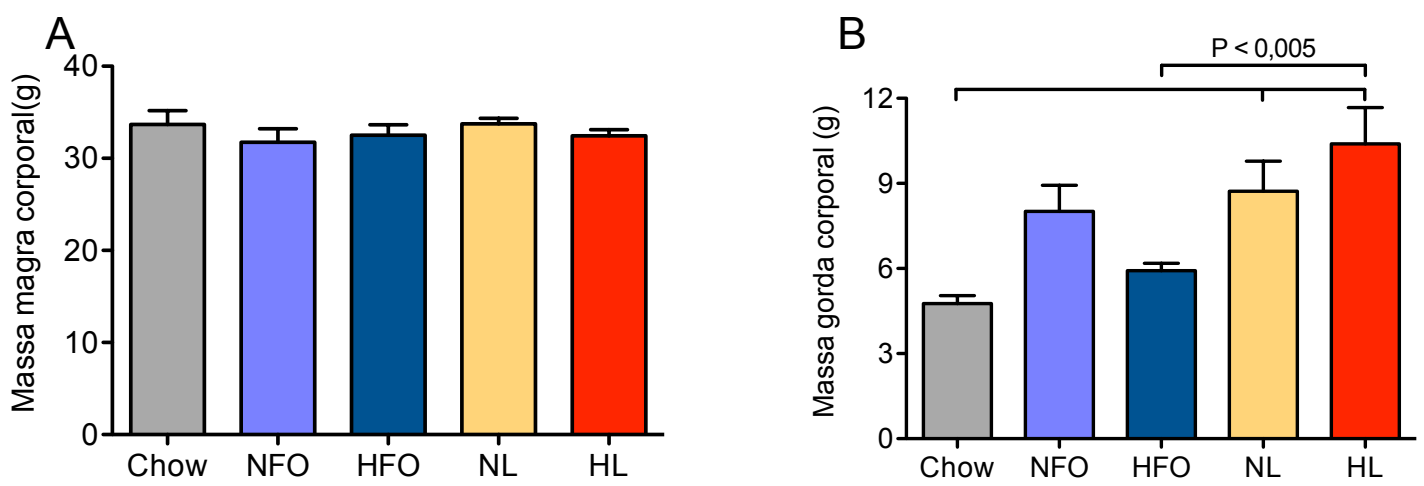

Figura 7. Composição corporal A - Massa magra corporal. B - Massa gorda corporal. Chow - grupo controle, NFO - grupo tratado com dieta normolipídica à base de óleo de peixe, HFO grupo tratado com dieta hiperlipídica à base óleo de peixe, NL - grupo tratado com dieta normolipídica à base de banha, $\mathrm{HL}$ - grupo tratado com dieta hiperlipídica à base de banha. (ANOVA com uma variável, seguida do teste de Tukey. $n=5$ ).

\subsection{Consumo de oxigênio}

O consumo de oxigênio em repouso apresentou uma resposta paradoxal. Considerando-se o maior consumo energético, o fenótipo magro dos camundongos HFO e os efeitos do óleo de peixe na oxidação de AG descritos por outros autores, seria esperado que os animais dos grupos NFO e HFO apresentassem maior consumo de $\mathrm{O}_{2}$. Entretanto, como pode ser observado na Figura 8, os grupos NFO e $\mathrm{HFO}$ apresentaram valores menores de $\mathrm{VO}_{2}$ quando comparados aos grupos $\mathrm{NL} e$ HL, sendo estes similares aos do grupo chow.

A produção de $\mathrm{CO}_{2}$ pelos animais do grupo $\mathrm{NL}$ foi significativamente maior que nos grupos HFO e NFO. Este dado é indicativo de maior oxidação de carboidratos em detrimento de substratos lipídicos, pelos animais deste grupo, quando comparados aos demais (Figuras 8B e 8C). Chama a atenção o fato de que o grupo NFO, cuja dieta apresentou os mesmos teores de lipídios e carboidratos, apresentou produção de $\mathrm{CO}_{2}$ reduzida em relação ao grupo NL. Entretanto, considerando-se o baixo consumo de oxigênio neste grupo, o resultado das avaliações de produção de $\mathrm{CO}_{2}$ é compatível.

Como esperado, o quociente respiratório (razão entre $\mathrm{VCO}_{2}$ e $\mathrm{VO}_{2}$ ) apresentou-se diminuído nos grupos que receberam dietas hiperlipídicas em relação àqueles que ingeriram dietas com teor normal de gordura (Chow, NFO e NL). Este 
efeito é decorrente da $\beta$-oxidação dos $A G$, onde há produção de equivalentes redutores culminando na utilização de oxigênio, sem geração de $\mathrm{CO}_{2}$. No catabolismo de carboidratos e gorduras, durante o ciclo de Krebs, além da geração de equivalentes redutores, há produção de $\mathrm{CO}_{2}$. Por isso, nos grupos tratados com dietas com conteúdo elevado de lipídios, o quociente respiratório apresentou-se reduzido. 

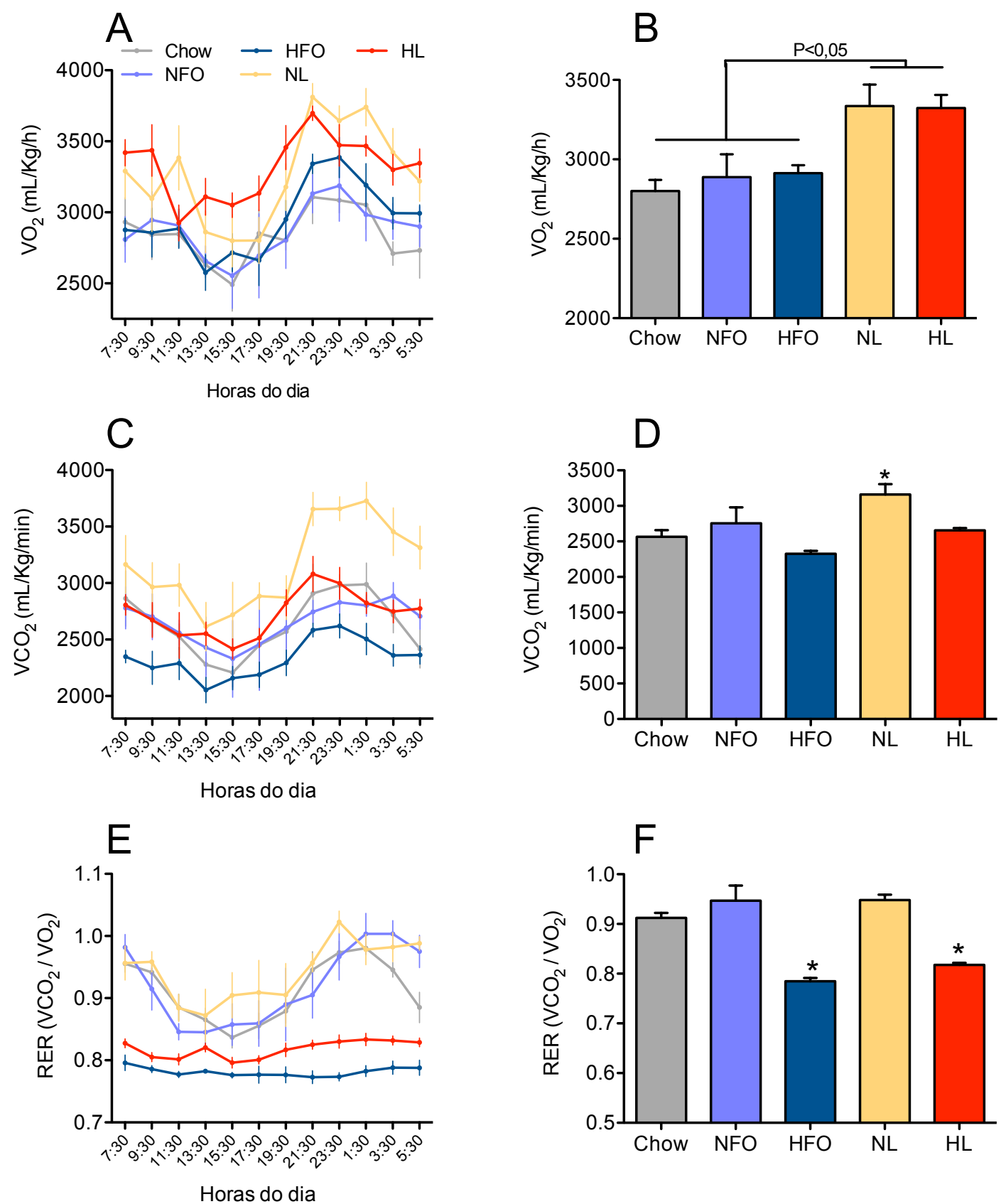

Figura 8. Calorimetria indireta. A - Consumo de oxigênio ao longo de 24 horas. B - Consumo médio de oxigênio. $\mathrm{C}$ - Produção de $\mathrm{CO}_{2}$ ao longo de $24 \mathrm{~h}$. D - Produção média de $\mathrm{CO}_{2}$. E Quociente respiratório ao longo de $24 \mathrm{~h}$. F - Quociente respiratório - média de $24 \mathrm{~h}$. Chow - grupo controle, NFO - grupo tratado com dieta normolipídica à base de óleo de peixe, HFO - grupo tratado com dieta hiperlipídica à base de óleo de peixe, NL - grupo tratado com dieta normolipídica à base de banha, $\mathrm{HL}$ - grupo tratado com dieta hiperlipídica à base de banha. $\left({ }^{*}=P<0,05\right.$. ANOVA com uma variável, seguida do teste de Tukey. $\left.n=5\right)$. 


\subsection{Homeostase glicêmica}

Os grupos tratados com óleo de peixe apresentaram valores de glicemia basal similares aos do grupo chow e mais baixos do que os observados nos animais tratados com banha. Não foram observadas diferenças entre NFO e HFO ou NL e HL (Figura 9). As concentrações de insulina também foram menores no grupo HFO, sendo estatisticamente semelhantes aos do grupo chow e menores que as do grupo HL.
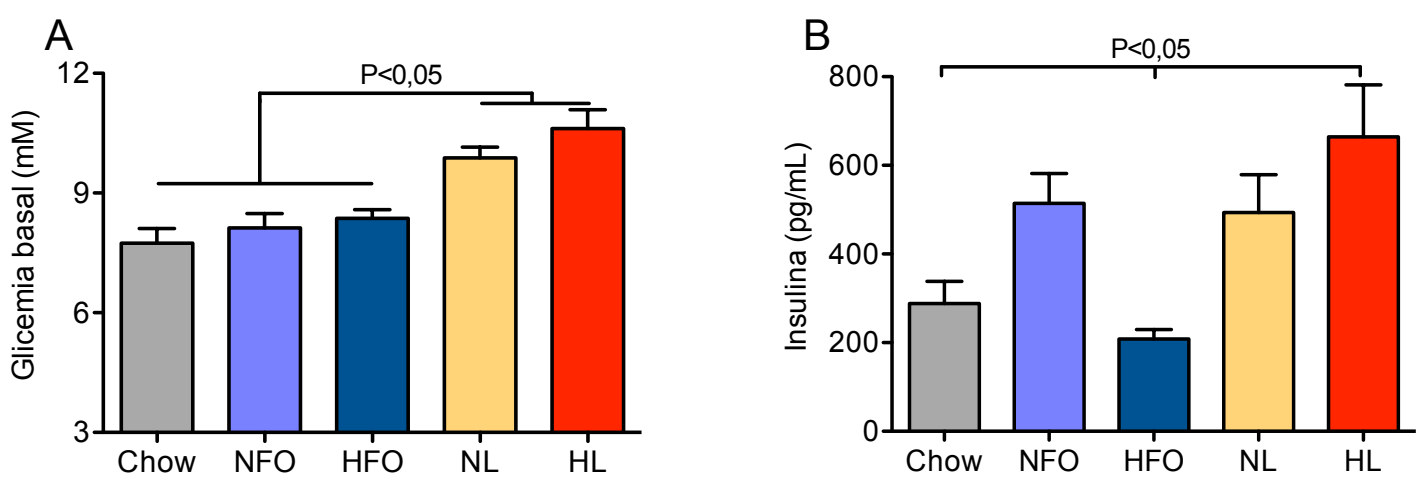

Figura 9. Glicemia e insulinemia basais. A - Glicemia basal - avaliada após 6 horas de jejum (Oneway ANOVA com teste de Tukey. $n=20$ ). $B$ - Insulinemia basal - medida realizada após 12 horas de jejum . Chow - grupo controle, NFO - grupo tratado com dieta normolipídica à base de óleo de peixe, HFO - grupo tratado com dieta hiperlipídica à base de óleo de peixe, NL - grupo tratado com dieta normolipídica à base de banha, $\mathrm{HL}$ - grupo tratado com dieta hiperlipídica à base de banha. (ANOVA com uma variável seguida do teste de Tukey. $n=5)$.

Durante o GTT, realizado na oitava semana de tratamento, os camundongos que receberam dietas contendo óleo de peixe exibiram menor aumento da glicemia em função do teste quando comparados aos animais tratados com banha. Tanto o aumento da glicemia, quanto a glicemia ao final do teste foram menores nestes grupos em relação a NL e HL. O efeito do tipo de lipídios presente na dieta é mais importante que a quantidade de gordura da dieta na determinação da glicemia assim como foi para o acúmulo de tecidos adiposo (Figura 10). 


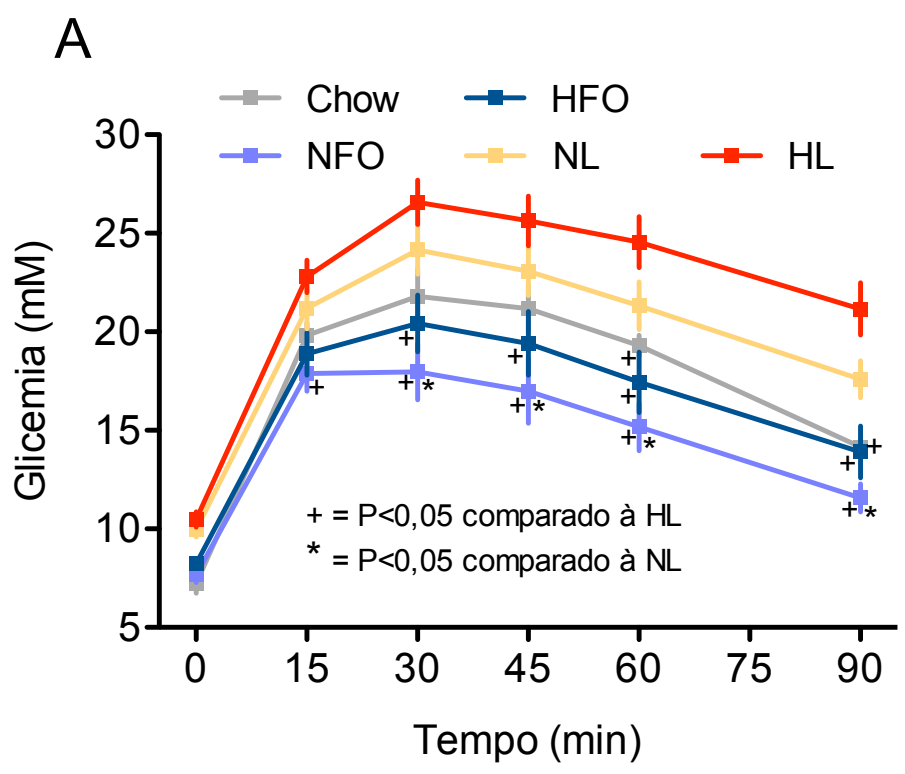

B

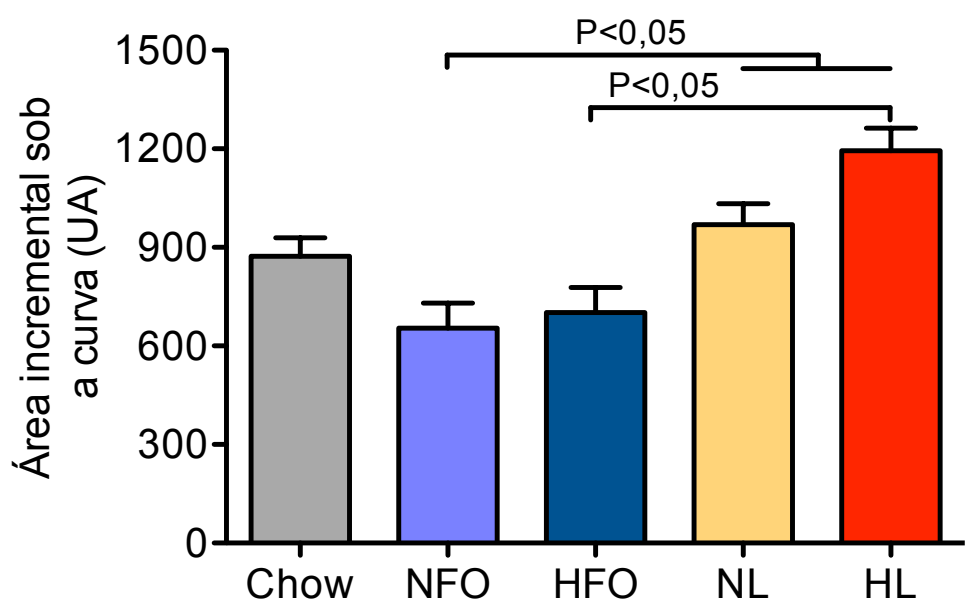

Figura 10. Teste de tolerância à glicose. A - Curva de glicemia durante o GTT. B - Área incremental sob a curva. Chow - grupo controle, NFO - grupo tratado com dieta normolipídica à base de óleo de peixe, HFO - grupo tratado com dieta hiperlipídica à base de óleo de peixe, NL - grupo tratado com dieta normolipídica à base de banha, $\mathrm{HL}$ - grupo tratado com dieta hiperlipídica à base de banha. (A - ANOVA com duas variáveis seguida do teste de Bonferroni $n=20$. B - ANOVA com uma variável, seguida do teste de Tukey. $n=20$ ). 
Apesar da grande diferença na resposta ao GTT observada entre os grupos, estes apresentaram a mesma resposta ao ITT. Os valores de glicemia antes da injeção de insulina foram diferentes, mas o decaimento da concentração de glicose no plasma durante o teste apresentou a mesma magnitude e velocidade entre os grupos (Figura 11).

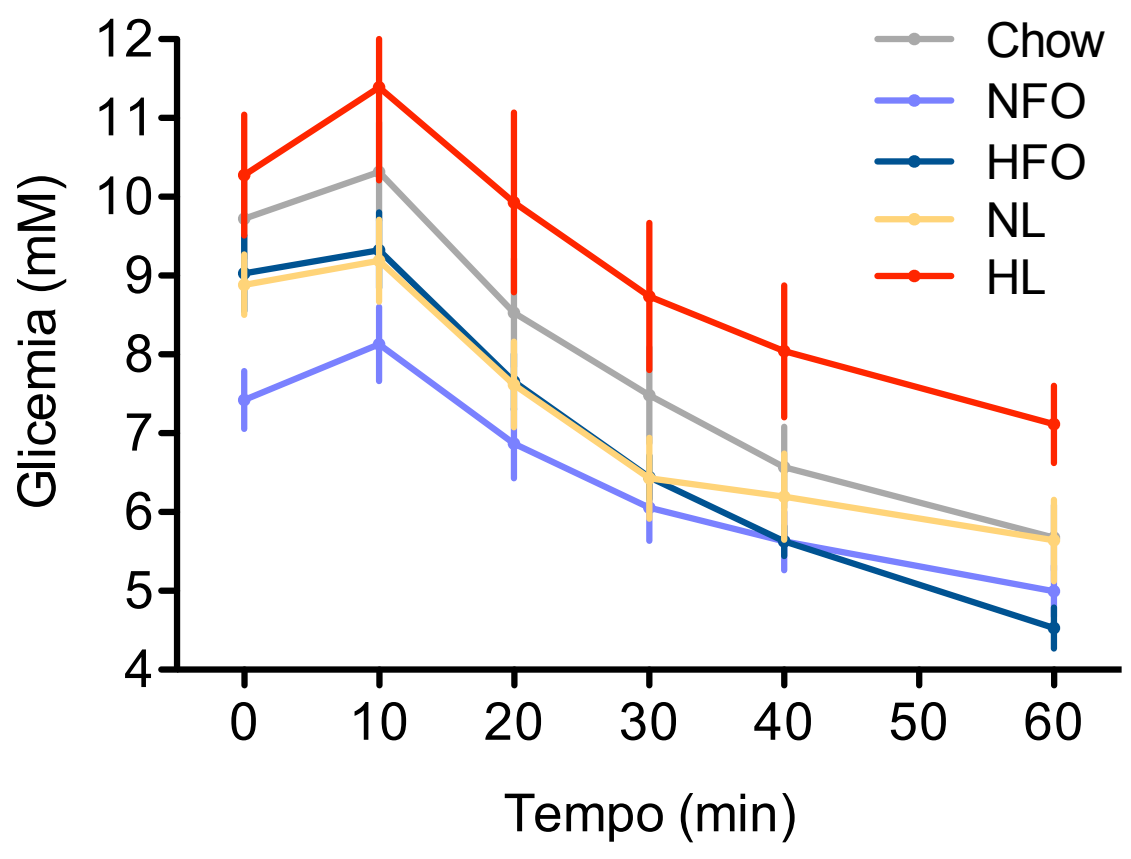

Figura 11. Teste de tolerância à insulina. Decaimento da glicemia durante o ITT. Chow - grupo controle, NFO - grupo tratado com dieta normolipídica à base de óleo de peixe, HFO grupo tratado com dieta hiperlipídica à base de óleo de peixe, NL - grupo tratado com dieta normolipídica à base de banha, $\mathrm{HL}$ - grupo tratado com dieta hiperlipídica à base de banha. Não foram encontradas diferenças estatísticas no decaimento da glicemia entre os grupos $(n=20)$. 
Da mesma forma que não foram observadas diferenças entre os grupos no ITT, também não foram detectadas diferenças nos ensaios para a captação de 2-desoxiglicose e incorporação de glicose em glicogênio no músculo sóleo isolado. Todos os grupos responderam de forma similar à insulina (300 $\mu \mathrm{Ul} / \mathrm{mL})$ (Figura 12).
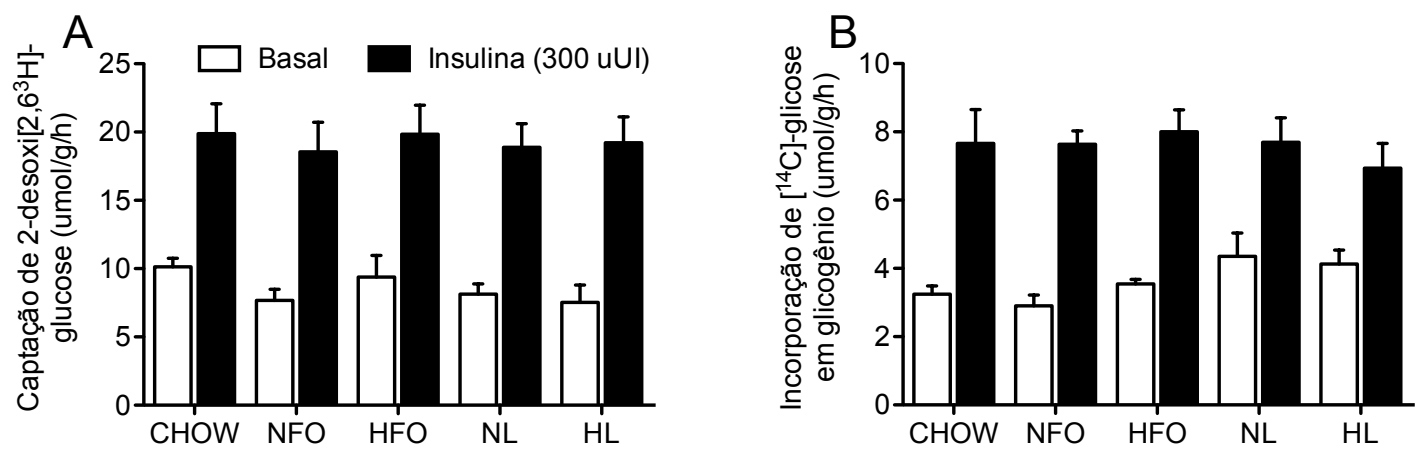

Figura 12. Captação de glicose e síntese de glicogênio em músculo isolado. A - Captação de 2desoxi-glicose em músculo sóleo isolado na ausência ou presença de $300 \mu \mathrm{UI} / \mathrm{mL}$ de insulina $(n=5)$. B - Síntese de glicogênio a partir de glicose na ausência ou presença de $300 \mu \mathrm{Ul} / \mathrm{mL}$ de insulina $(n=5)$. Chow - grupo controle, NFO - grupo tratado com dieta normolipídica à base de óleo de peixe, HFO - grupo tratado com dieta hiperlipídica à base de óleo de peixe, NL - grupo tratado com dieta normolipídica à base de banha, $\mathrm{HL}$ - grupo tratado com dieta hiperlipídica à base de banha. Não foram encontradas diferenças estatísticas na captação de glicose e conversão de glicose à glicogênio entre os grupos. 


\subsection{Concentrações de lipídios no plasma e tecidos e oxidação de ácidos graxos}

Houve diminuição das concentrações de colesterol plasmático nos grupos NFO e HFO em relação aos grupos NL e HL. O grupo HFO também apresentou valores menores de triacilgliceróis e NEFA no plasma (Figura 13).
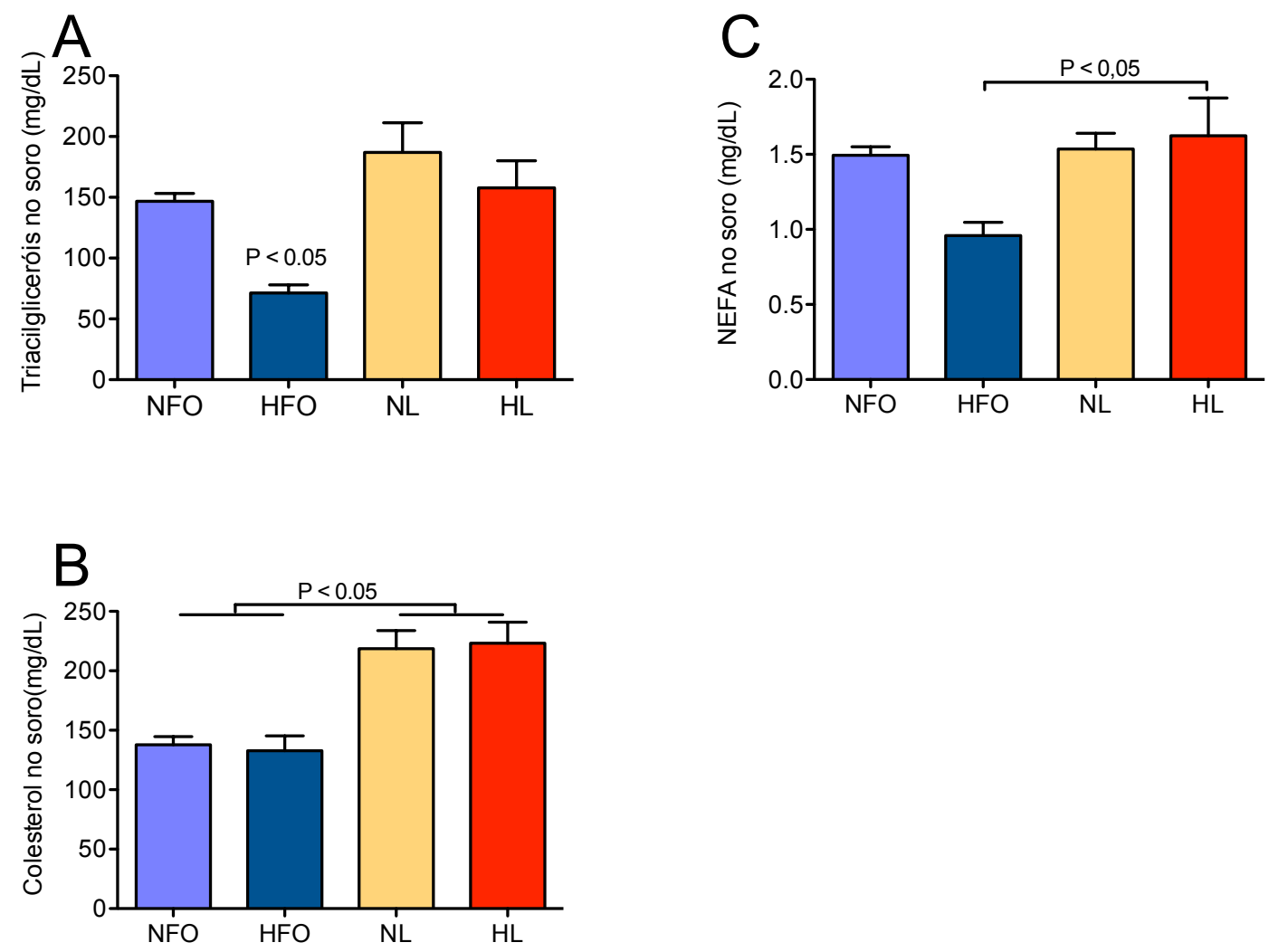

Figura 13. Lipídios plasmáticos. A - Triacilgliceróis no plasma. B - Colesterol total no plasma. C Ácidos graxos não esterificados no plasma. Chow - grupo controle, NFO - grupo tratado com dieta normolipídica à base de óleo de peixe, HFO - grupo tratado com dieta hiperlipídica à base de óleo de peixe, NL - grupo tratado com dieta normolipídica à base de banha, $\mathrm{HL}$ - grupo tratado com dieta hiperlipídica à base de banha. (ANOVA com uma variável, seguida do teste de Tukey. $n=8$ )

Os camundongos tratados com óleo de peixe apresentaram as menores concentrações de diacilgliceróis e triacilgliceróis no fígado, quando comparados com os grupos NL e HL. Os valores encontrados nos grupos NFO e HFO foram semelhantes àqueles do grupo chow. Apesar das diferenças observadas no conteúdo de triacilgliceróis e diacilgliceróis no fígado, o conteúdo de triacilgliceróis no músculo gastrocnêmio foi semelhante entre os grupos (Figura 14). 

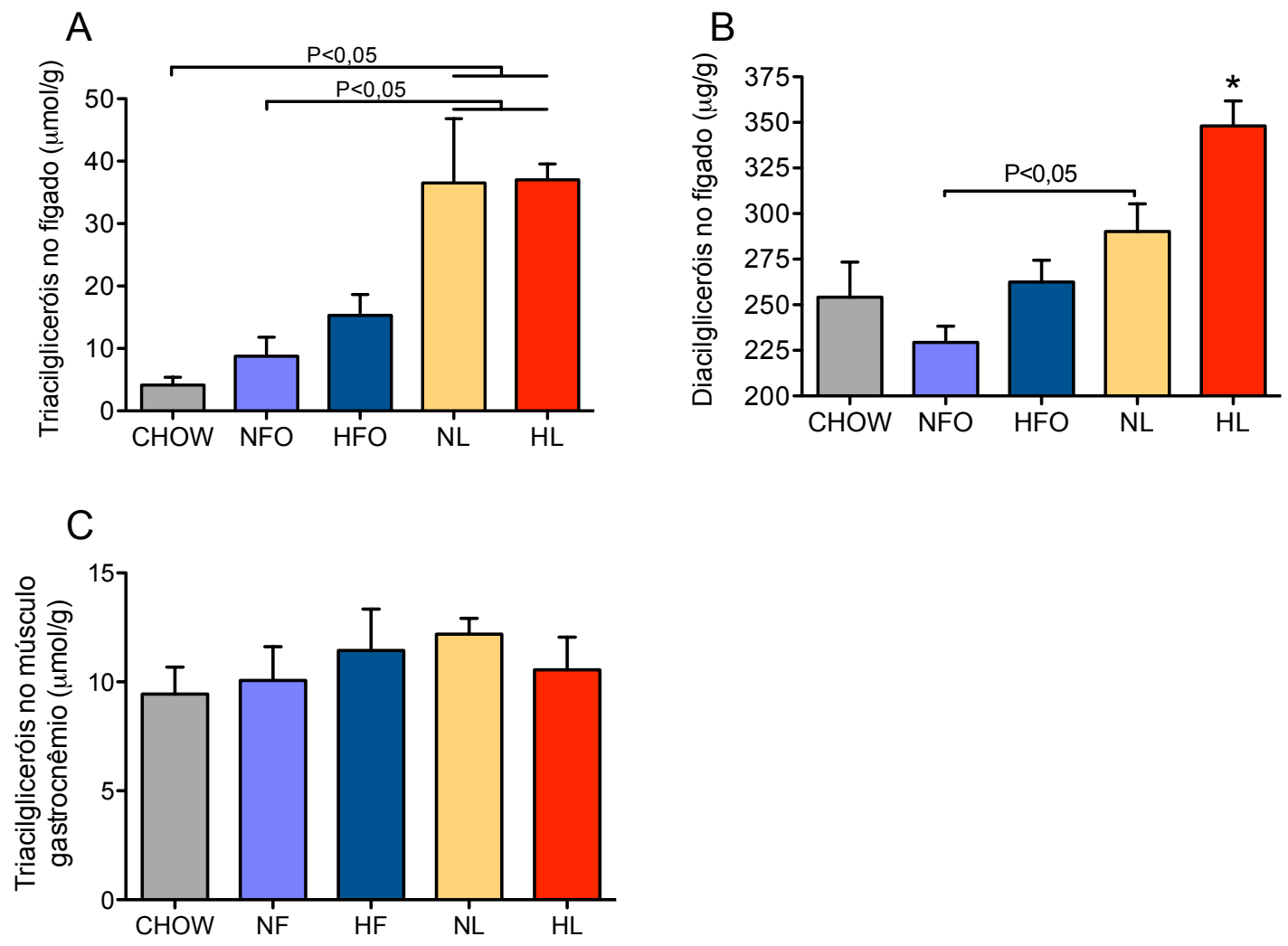

Figura 14. Conteúdo de lipídios no fígado e músculo gastrocnêmio. A - Triacilgliceróis no fígado. B - Diacilgliceróis no fígado. C - Triacilgliceróis no músculo gastrocnêmio. Chow - grupo controle, NFO - grupo tratado com dieta normolipídica à base de óleo de peixe, HFO grupo tratado com dieta hiperlipídica à base de óleo de peixe, NL - grupo tratado com dieta normolipídica à base de banha, $\mathrm{HL}$ - grupo tratado com dieta hiperlipídica à base de banha. (ANOVA com uma variável, seguida do teste de Tukey. $n=5$ ).

A oxidação de palmitato a $\mathrm{CO}_{2}$ foi menor em homogenatos de fígados de camundongos tratados com óleo de peixe. Neste parâmetro, os grupos NL e HL apresentaram-se semelhantes ao grupo chow. Por outro lado, a produção de ASM a partir do palmitato foi maior no fígado dos animais do grupo HFO, indicando que este AG foi direcionado para a $\beta$-oxidação mas não foi oxidado completamente. É importante esclarecer que os metabólitos referidos como ASM são moléculas marcadas com ${ }^{14} \mathrm{C}$ e, por isso, geradas a partir do carbono do grupo carboxila do ácido palmítico. Este carbono é removido juntamente com o segundo carbono da molécula de $A G$ através da $\beta$-oxidação gerando acetil $\operatorname{Co} A$, que pode ser direcionado ao ciclo de Krebs ou a outras vias metabólicas. Como estas moléculas permanecem solúveis no meio, não sendo precipitadas após a adição do ácido perclórico e por não terem sido identificadas, são conjuntamente referidas como metabólitos solúveis em ácido (ASM - do inglês acid soluble metabolites). Assim, no 
fígado dos animais tratados com dieta hiperlipídica à base de óleo de peixe, a oxidação parcial de palmitato aumentou em comparação aos animais tratados com banha de suínos, indicando que a atividade da $\beta$-oxidação estava aumentada. Não foram detectadas diferenças na oxidação de ácido palmítico em homogenatos do músculo tibialis (Figura 15).
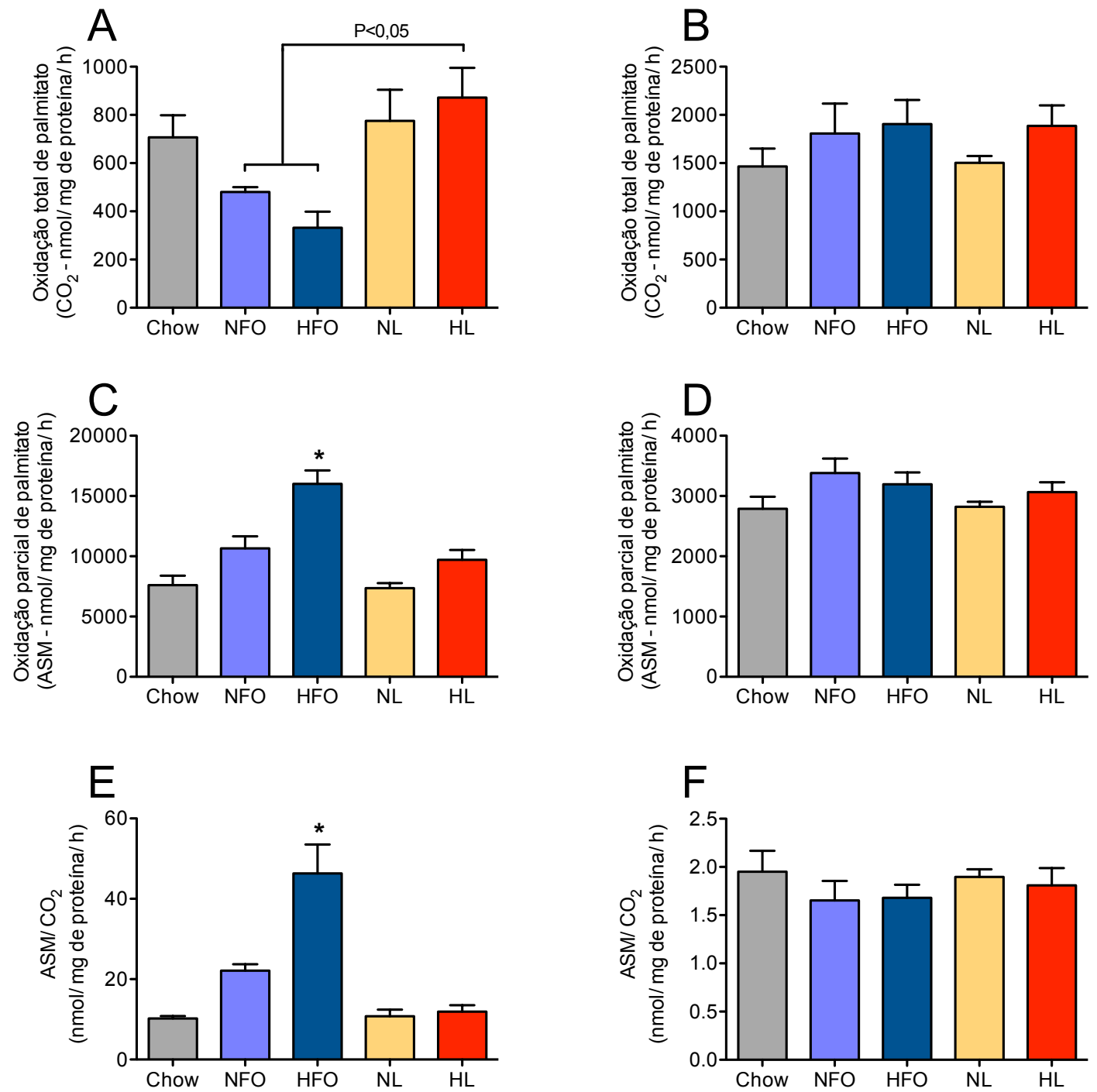

Figura 15. Oxidação de ácido palmítico in vitro. A - Produção de $\mathrm{CO}_{2}$ em homogenatos de fígado. $\mathrm{B}$ - Produção de $\mathrm{CO}_{2}$ em homogenatos de músculo gastrocnêmio. C - Produção de metabólitos solúveis em ácido em homogenatos de fígado. D - Produção de metabólitos solúveis em ácido em homogenatos de músculo gastrocnêmio. E - Razão entre a produção de $\mathrm{CO}_{2}$ e metabólitos solúveis em ácido em homogenatos de fígado. $\mathrm{F}$ - Razão entre a produção de $\mathrm{CO}_{2}$ e metabólitos solúveis em ácido em homogenatos de músculo gastrocnêmio. Chow - grupo controle, NFO - grupo tratado com dieta normolipídica à base de óleo de peixe, HFO - grupo tratado com dieta hiperlipídica à base de óleo de peixe, NL - grupo tratado com dieta normolipídica à base de banha, HL - grupo tratado com dieta hiperlipídica à base de banha. $\left({ }^{*}=\mathrm{P}<0,05\right.$. ANOVA com uma variável, seguida do teste de Tukey. $n=5$ ). 


\subsection{Atividade mitocondrial e peroxissomal}

A atividade das enzimas do ciclo de Krebs, citrato sintase (CS) e succinato desidrogenase (SDH), não foi diferente entre os grupos em homogenatos de músculo gastrocnêmio. No fígado, a única diferença observada foi a diminuição da atividade da CS no grupo HFO (Figura 16).
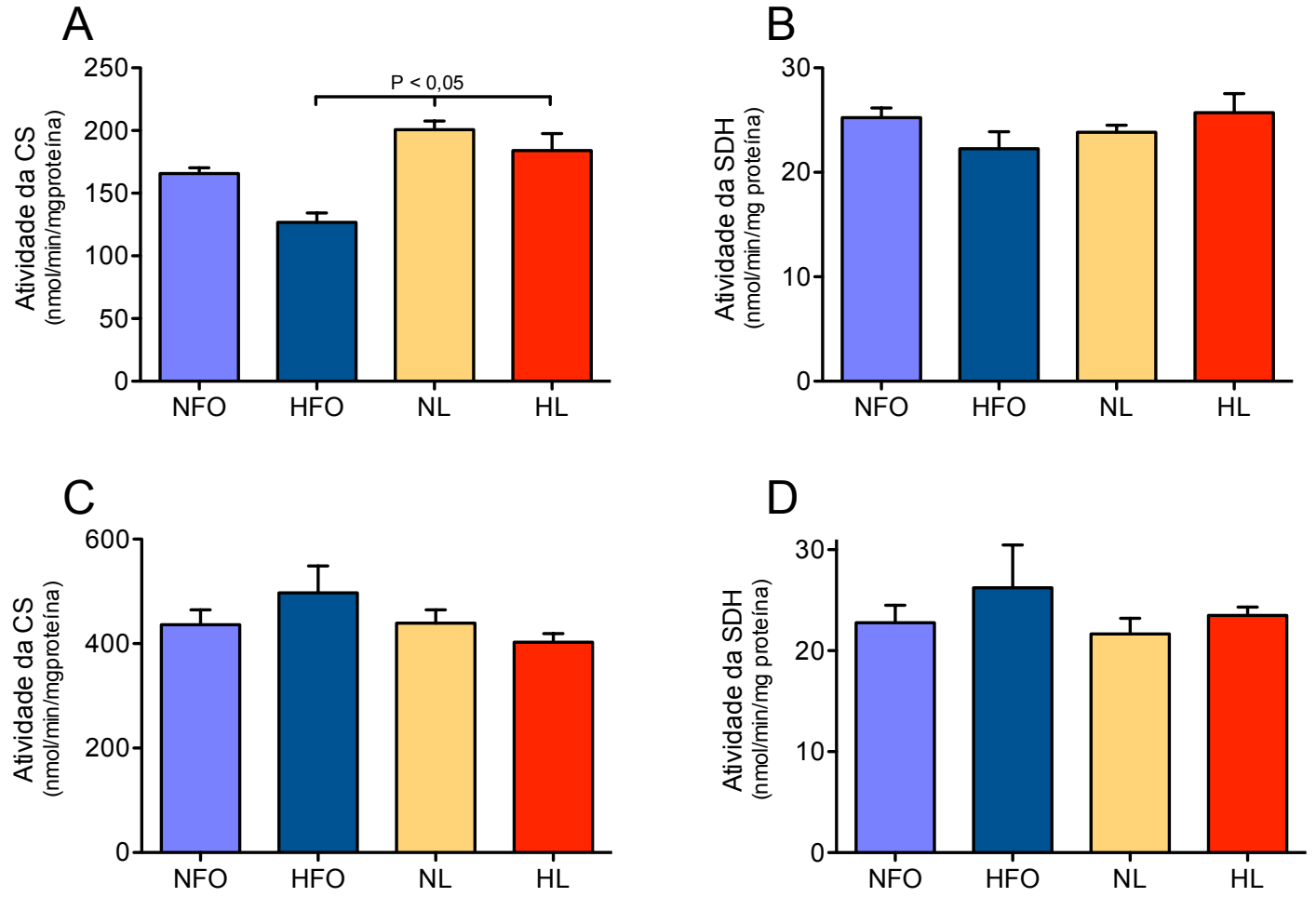

Figura 16. Enzimas do ciclo de Krebs. A - Atividade da citrato sintase no fígado. B - Atividade da succinato desidrogenase no fígado. C - Atividade da citrato sintase no músculo gastrocnêmio. D - Atividade da succinato desidrogenase no músculo gastrocnêmio. NFO grupo tratado com dieta normolipídica à base de óleo de peixe, HFO - grupo tratado com dieta hiperlipídica à base óleo de peixe, NL - grupo tratado com dieta normolipídica à base de banha, HL - grupo tratado com dieta hiperlipídica à base de banha. (ANOVA com uma variável, seguida do teste de Tukey. $n=5$ ).

Ao contrário da atividade das enzimas do ciclo de Krebs, a atividade de três enzimas envolvidas na $\beta$-oxidação foi modulada pelos tratamentos. No fígado dos camundongos do grupo HFO, houve aumento na atividade da acil CoA oxidase (ACO), (enzima encontrada em peroxissomos exclusivamente), $\beta$-hidroxi acil CoA desidrogenase (BHAD) e desidrogenase de acil CoA de cadeia média (MCAD), ubíquas em mitocôndrias e peroxissomos. A atividade da MCAD também apresentou-se elevada no grupo NFO em relação aos grupos NL e HL. No músculo 

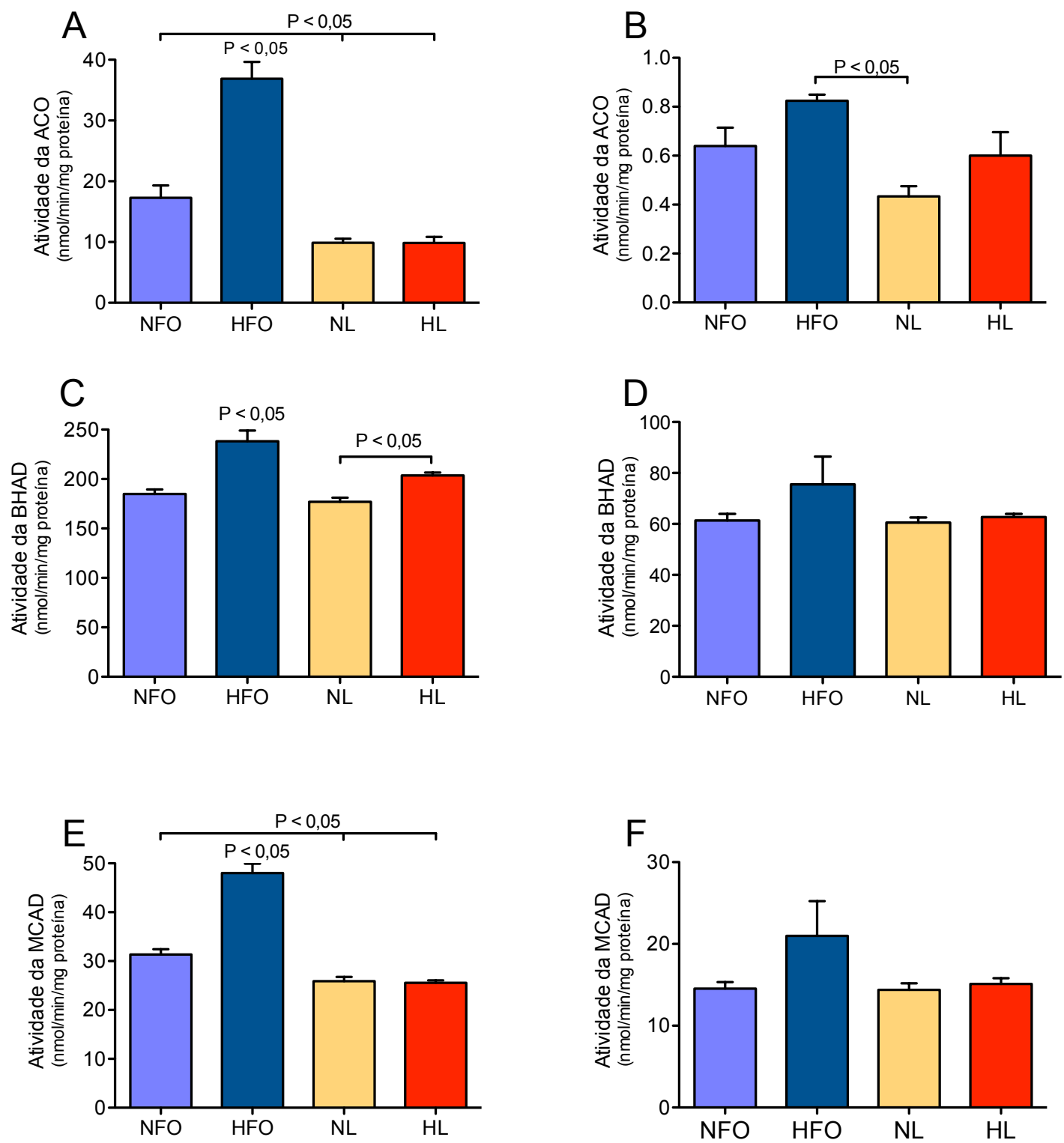

Figura 17. Enzimas da $\beta$-oxidação. A - Atividade da acil CoA oxidase no fígado. B - Atividade da acil CoA oxidase no músculo. $C$ - Atividade da $\beta$-hidroxi acil CoA desidrogenase no fígado. D Atividade da $\beta$-hidroxi acil CoA desidrogenase no músculo gastrocnêmio. $E$ - Atividade da desidrogenase de acil CoA de cadeia média no fígado. F - Atividade da desidrogenase de acil CoA de cadeia média no músculo gastrocnêmio. Chow - grupo controle, NFO - grupo tratado com dieta normolipídica à base de óleo de peixe, HFO - grupo tratado com dieta hiperlipídica à base de óleo de peixe, NL - grupo tratado com dieta normolipídica à base de banha, HL - grupo tratado com dieta hiperlipídica à base de banha. (ANOVA com uma variável, seguida do teste de Tukey. $n=5$ ). 
No fígado, o conteúdo de algumas subunidades dos cinco complexos da cadeia transportadora de elétrons (CTE) não apresentou modulação pelos tratamentos, assim como o conteúdo da carnitina palmitoil transferase-1 (CPT-1) (Figura 18). Por outro lado, o conteúdo de PMP-70, um marcador de membranas de peroxissomos apresentou-se aumentado no fígado dos animais do grupo HFO, sugerindo aumento no número de peroxissomos neste grupo. O conteúdo de ACS também foi positivamente modulado no fígado dos animais do grupo HFO (Figura 19).

A

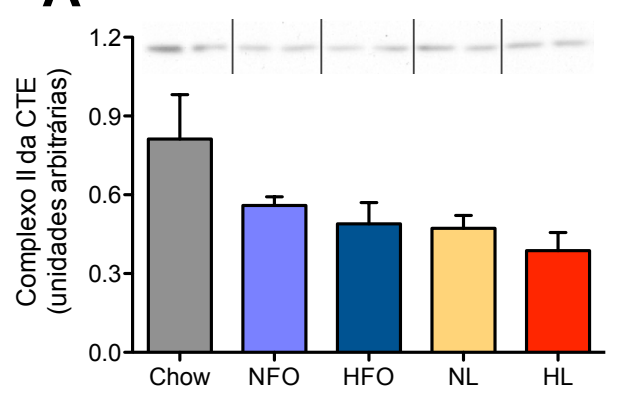

C
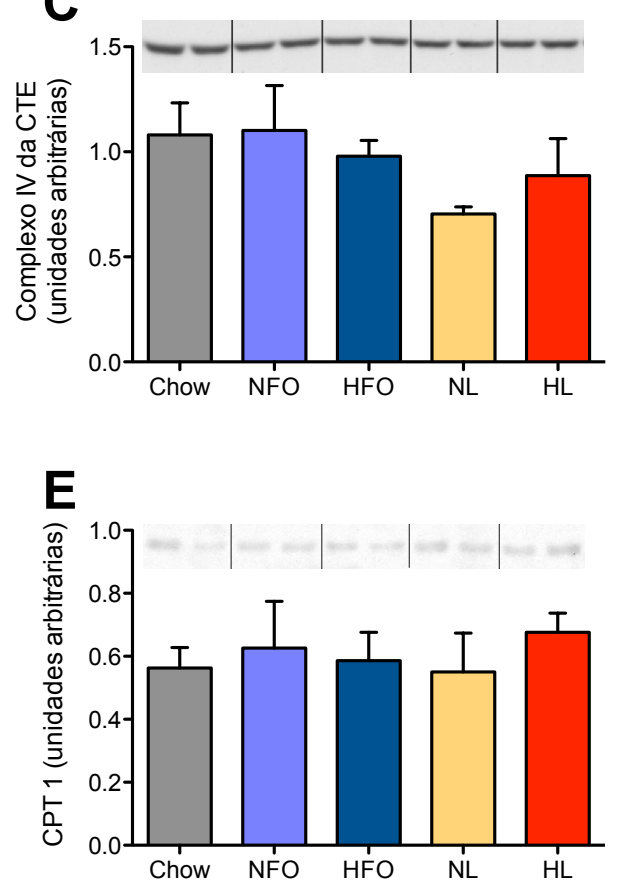

B

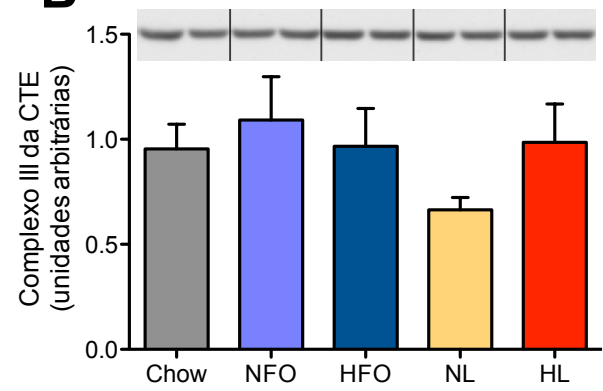

D
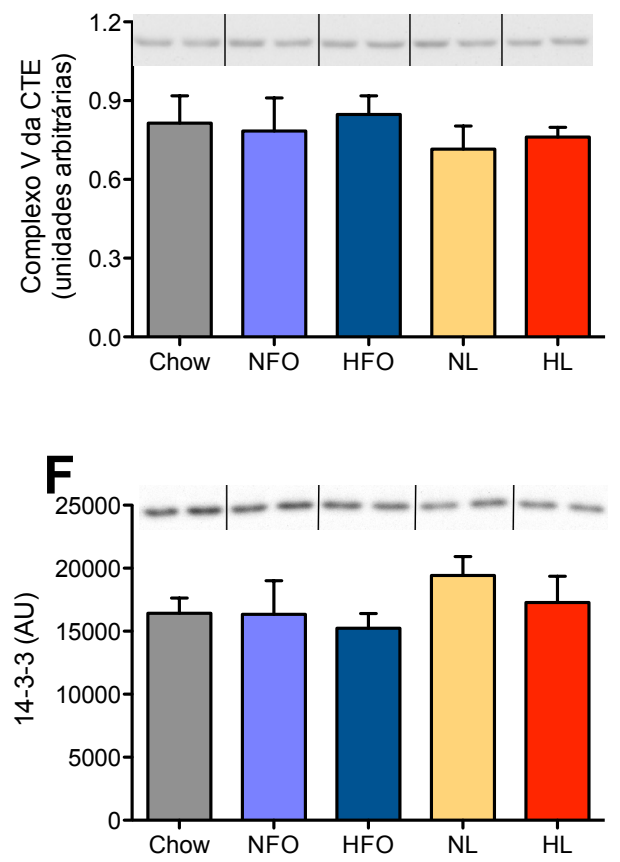

Figura 18. Conteúdo de proteínas mitocondriais. Conteúdo hepático de subunidades de quatro complexos da cadeia transportadora de elétrons (A - D), de carnitina palmitoil transferase-1 (E) e da proteína Pan 14-3-3. Chow - grupo controle, NFO - grupo tratado com dieta normolipídica à base de óleo de peixe, HFO - grupo tratado com dieta hiperlipídica à base de óleo de peixe, NL - grupo tratado com dieta normolipídica à base de banha, HL - grupo tratado com dieta hiperlipídica à base de banha. Sem diferenças estatisticas (ANOVA com uma variável, seguida do teste de Tukey. $n=5$ ). 

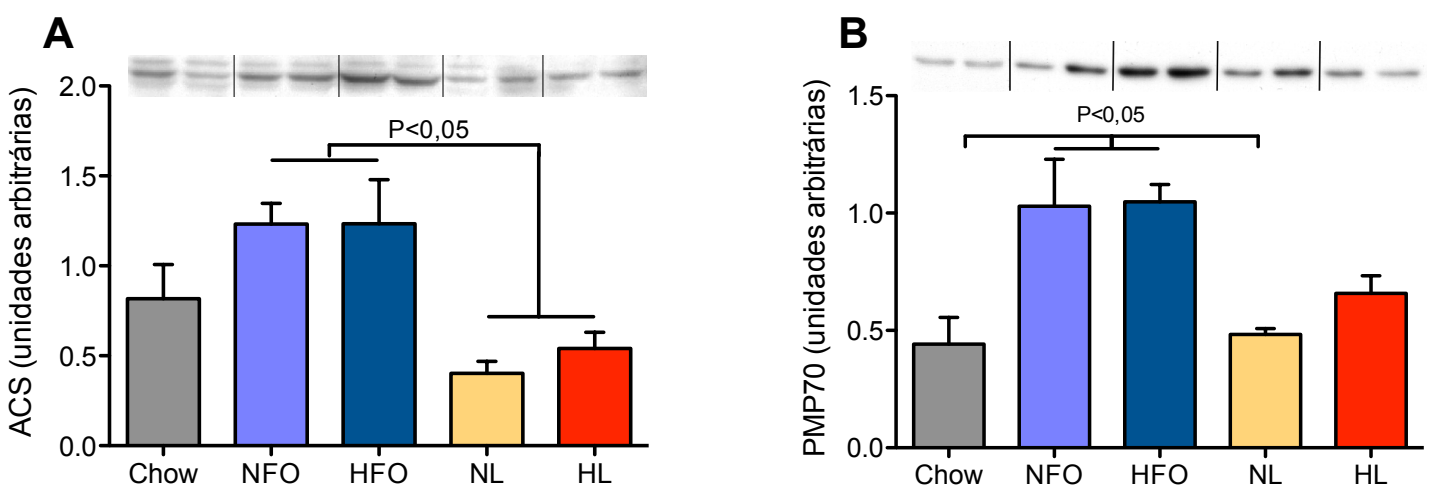

Figura 19. Conteúdo de ACS e PMP70. A - Conteúdo de Acil CoA sintetase no fígado. B - Conteúdo hepático de PMP70, um marcador de peroxissomos. (ANOVA com uma variável, seguida do teste de Tukey. $n=5$ ).

Os hepatócitos isolados dos camundongos tratados com $\mathrm{Wy}, 14-643$ produziram $60 \%$ menos $\mathrm{CO}_{2}$, mas geraram aproximadamente $60 \%$ mais ASM que aqueles isolados dos camundongos que não receberam esta droga (Figura 20). Os efeitos do Wy,14-643 na oxidação de palmitato foram semelhantes aos efeitos do óleo de peixe. Esta é uma evidência de que os efeitos do óleo de peixe na modulação do metabolismo hepático de lipídios ocorre através dos peroxissomos, pela ativação do PPAR.
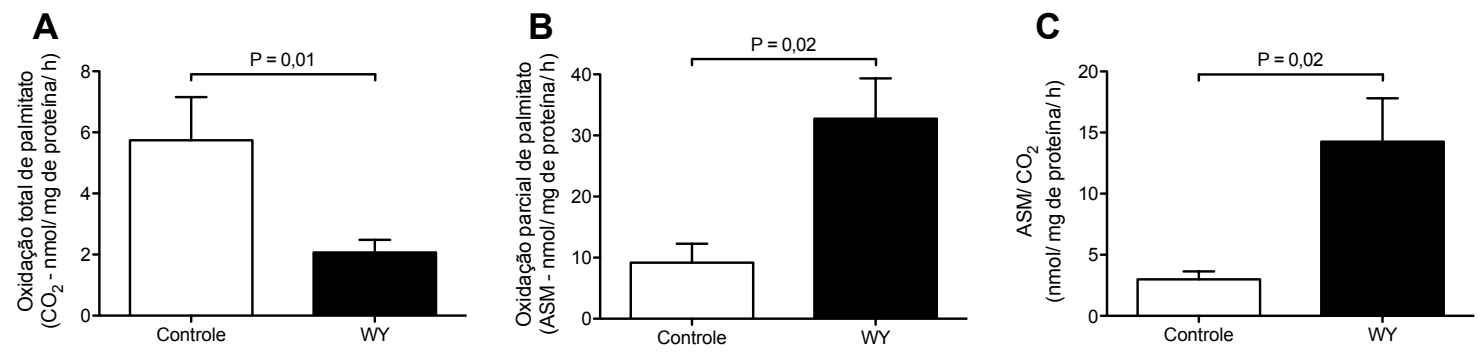

Figura 20. Wy-14,643 e oxidação de ácido palmítico. A - Produção de $\mathrm{CO}_{2}$ em hepatócitos isolados de camundongos tratados ou não com Wy 14,643. B - Produção de metabólitos solúveis em ácido nos hepatócitos isolados de camundongos tratados ou não com Wy 14,643. C Razão entre a produção de $\mathrm{CO}_{2}$ e metabólitos solúveis em ácido em hepatócitos isolados de camundongos tratados ou não com Wy 14,643. (Teste T de Student. $n=5$ ). 


\subsection{Lipogênese}

A síntese de lipídios foi drasticamente modulada pelos tratamentos. Os grupos NFO e NL receberam dietas com quantidades muito baixas de gordura, mas apesar disso apresentaram massa gorda em valores similares aos do grupo HL. Estes resultados são indicativos de lipogênese estimulada.

A
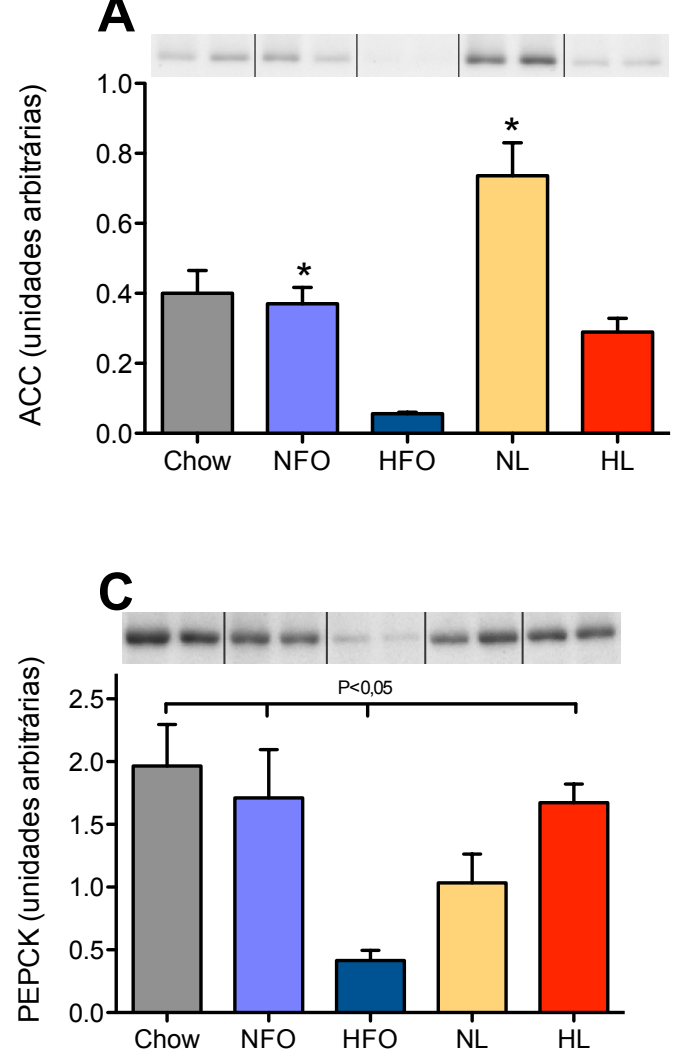

B

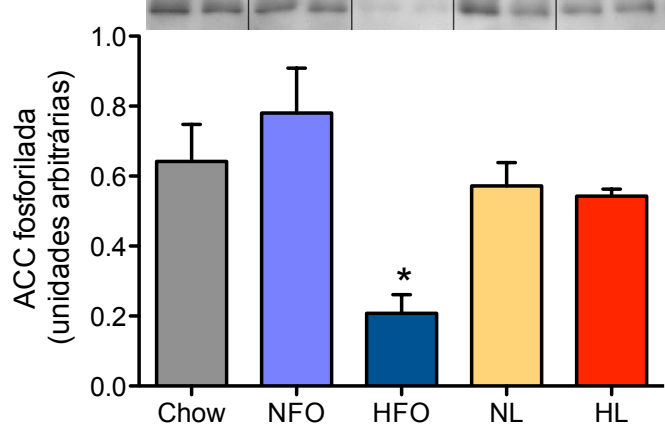

D

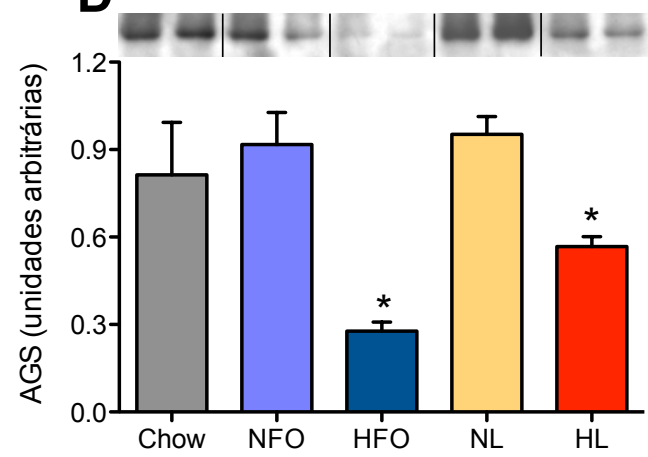

Figura 21. Enzimas lipogênicas. Conteúdo hepático de acetil CoA carboxilase, fosfoenolpiruvato carboxiquinase, ácido graxo sintase e fosforilação da acetil CoA carboxilase. Contteúdo expresso em unidades arbitrárias, normalizando-se os valores pela proteína pan 14-3-3. Chow - grupo controle, NFO - grupo tratado com dieta normolipídica à base de óleo de peixe, HFO - grupo tratado com dieta hiperlipídica à base de óleo de peixe, NL - grupo tratado com dieta normolipídica à base de banha, HL - grupo tratado com dieta hiperlipídica à base de banha. Não ocorreram diferenças estatisticamente significativas (ANOVA com uma variável, seguida do teste de Tukey. $n=5$ ).

Como pode ser observado na Figura 21, o conteúdo da acetil CoA carboxilase (ACC), enzima responsável pela condensação de duas unidades de acetil CoA, passo inicial da síntese de AG, assim como o da ácido graxo sintase (AGS) e da fosfoenolpiruvato carboxiquinase (PEPCK), envolvida na síntese de glicerol foi similar entre os grupos chow, NFO, NL e HL. Além disso, a fosforilação da ACC foi 
muito mais intensa no grupo NL que nos demais. Estas modulações positivas no conteúdo e atividade de enzimas lipogênicas são indicativos de síntese aumentada de lipídios e justificam os resultados apresentados anteriormente referentes ao peso dos depósitos de tecido adiposo e de massa gorda. O grupo HFO foi o que apresentou o menor conteúdo destas enzimas, observação coerente com o menor teor de lipídios encontrado no fígado e nos depósitos de gordura dos animais deste grupo. Este efeito inibidor da lipogênese é característico do óleo de peixe e existem evidências de que este fenômeno não dependa da ativação do PPAR (WAKUTSU et al., 2010).

Outro indício de estímulo da síntese de AG no grupo NL é o alto teor de ácido oléico encontrado no fígado, plasma e TAE deste grupo (Figura 22). Como este AG é produzido nos passos iniciais da via de síntese destas moléculas, a razão entre a concentração de AG monoinsaturados e de seus precursores (ácido palmítico e esteárico) fornece evidência adicional da síntese aumentada de AG. A concentração destes AG também pode ser influenciada pela dieta e experimentos adicionais são necessários para diferenciar qual é a proporção destes AG proveniente de síntese de novo e da dieta. Apesar desta limitação, esta razão pode ser utilizada como índice de atividade da estearoil CoA dessaturase, enzima que insere a dupla ligação nos ácidos palmítico e esteárico, convertendo-os em palmitoléico e oléico (Figura 23). O acúmulo de PUFA n-3 no fígado e soro dos grupos NFO e HFO já era esperado e está apresentado na Figura 22. 

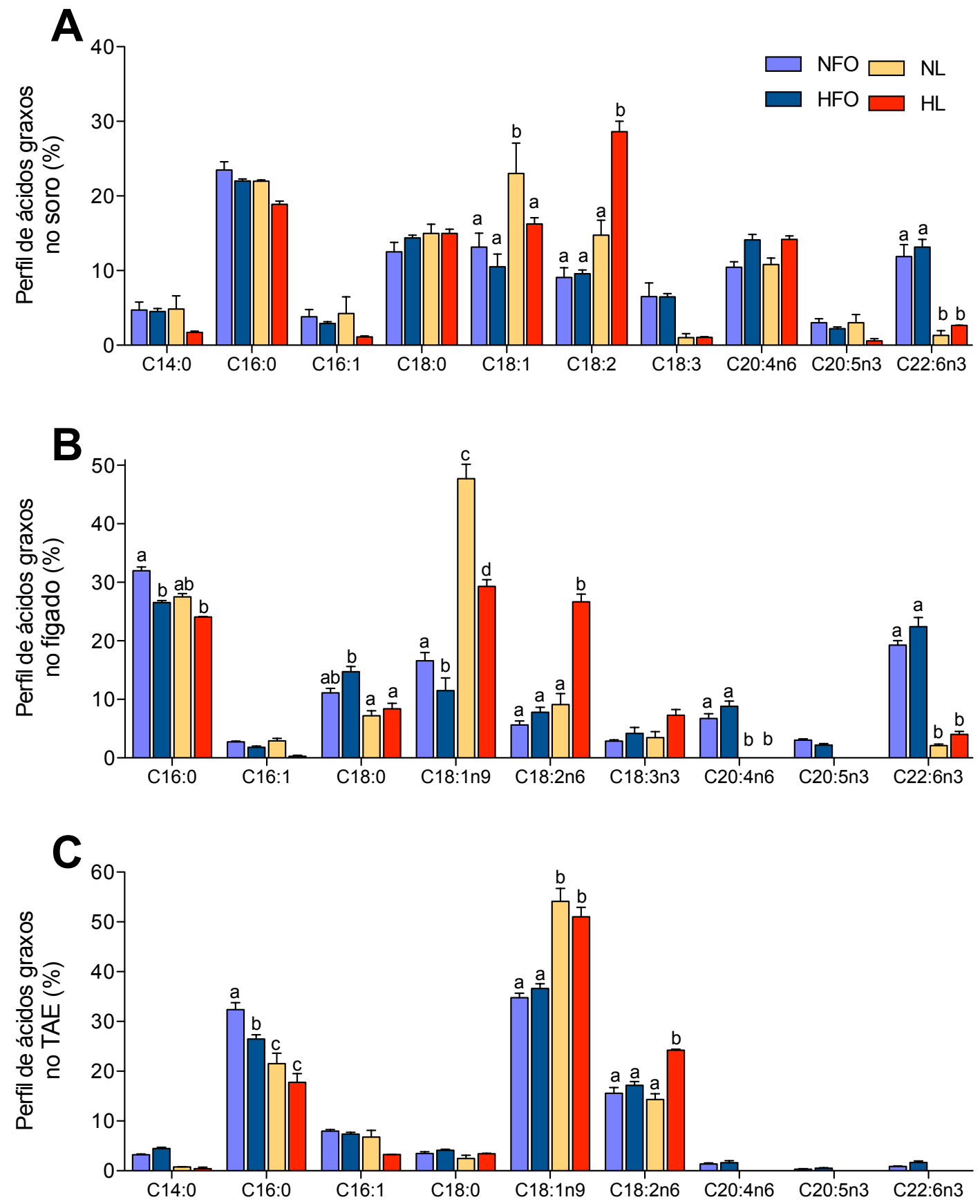

Figura 22. Composição de ácidos graxos. Composição em ácidos graxos no soro, fígado e tecido adiposo epididimal. Resultados expressos em percentagem da participação de cada AG na composição dos lipídios totais de cada tecido. Chow - grupo controle, NFO - grupo tratado com dieta normolipídica à base de óleo de peixe, HFO - grupo tratado com dieta hiperlipídica à base de óleo de peixe, NL - grupo tratado com dieta normolipídica à base de banha, HL - grupo tratado com dieta hiperlipídica à base de banha. Não ocorreram diferenças estatisticamente significativas (ANOVA com duas variáveis, seguida do teste de Bonferroni. $n=5$. As diferenças entre os grupos, quando existentes, estão indicadas por letras diferentes). 

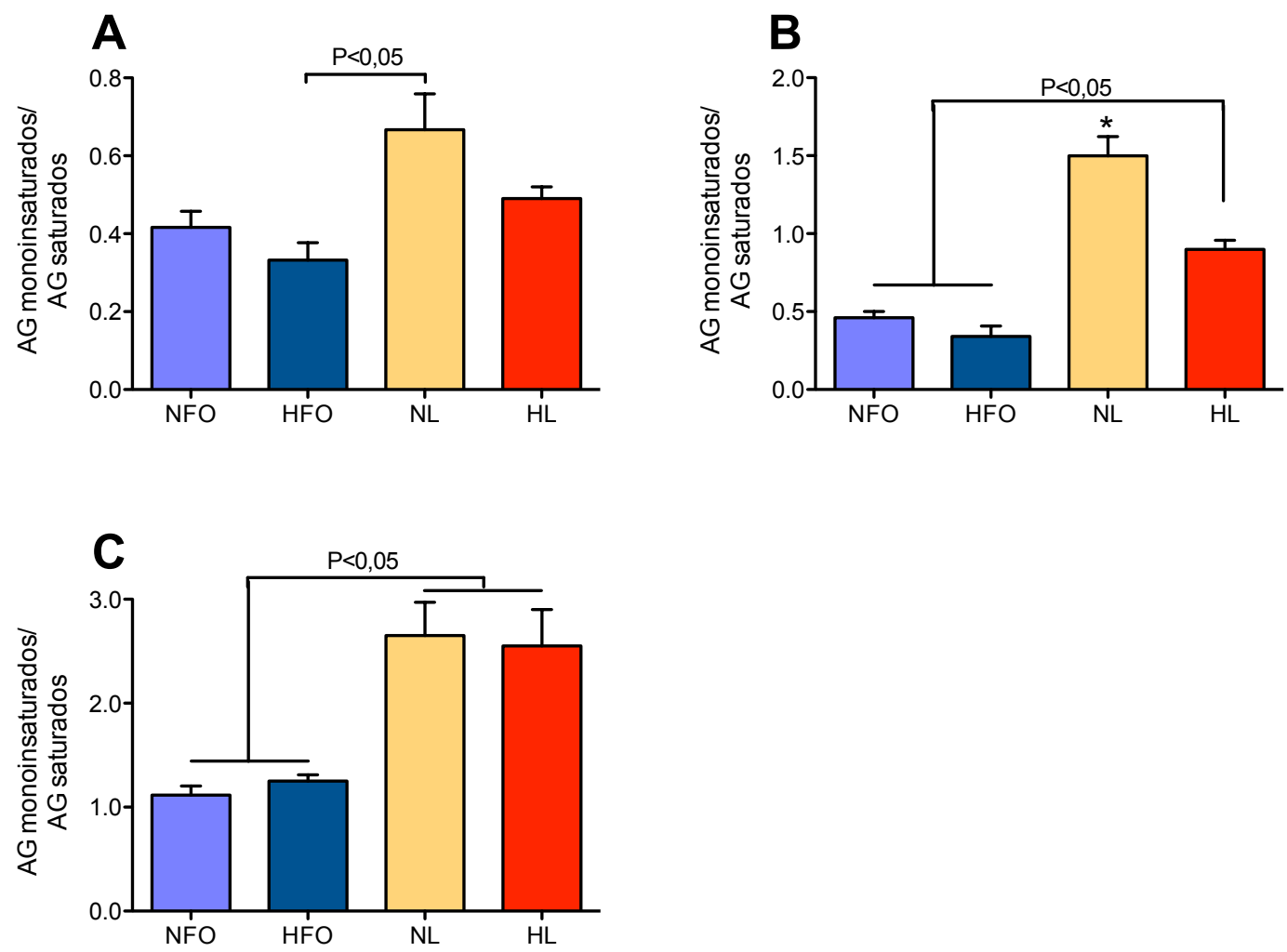

Figura 23. Razão dos ácidos graxos monoinsaturados/ ácidos graxos saturados. Razão entre a concentração de $A G$ monoinsaturados e $A G$ saturados ácidos graxos no soro (A), fígado (B) e tecido adiposo epididimal (C). Chow - grupo controle, NFO - grupo tratado com dieta normolipídica à base de óleo de peixe, HFO - grupo tratado com dieta hiperlipídica à base de óleo de peixe, NL - grupo tratado com dieta normolipídica à base de banha, $\mathrm{HL}$ - grupo tratado com dieta hiperlipídica à base de banha. Não ocorreram diferenças estatisticamente significativas (ANOVA com uma variável, seguida do teste de Tukey. $n=$ $5)$. 


\section{Discussão}

Os resultados de composição corporal deixam claro que para os camundongos utilizados como modelo animal neste trabalho, o tipo de AG presente nas dietas é mais importante que a quantidade de lipídios totais na indução da obesidade. Não foram detectadas diferenças de peso entre os grupos NFO e HFO ou NL e HL, embora NFO e NL recebessem dietas com conteúdos de lipídios 10 vezes menores que as dietas dos grupos HFO e HL. Apesar da resistência à obesidade induzida pela dieta observada nos camundongos Swiss e mesmo com a menor absorção de energia, decorrente da menor ingestão energética, o grupo HL apresentou maiores valores mais elevados de massa corporal, sendo esta uma das principais diferenças entre os grupos HFO e HL. Dados gerados pelo nosso grupo são indicativos de que o aumento de massa corpórea e massa gorda é mais acentuado em camundongos mais suscetíveis à obesidade induzida pela dieta como os C57/BI6.

O aumento de tecido adiposo nos depósitos epididimal e retroperitoneal apresentou o mesmo padrão observado nos resultados de massa corpórea: os camundongos foram mais sensíveis à variação no tipo de AG da dieta do que na quantidade de lipídios ingeridos. Por outro lado, a quantidade de tecido adiposo inguinal seguiu o mesmo padrão entre os grupos que a quantidade de massa gorda corporal, sendo que os grupos HFO e chow apresentaram os menores valores para estes parâmetros. Chama a atenção o fato de que o grupo NFO apresentou os menores depósitos de TAE e TAR, assim como os grupos chow e HFO, mas um dos valores mais elevados de massa de TAl e massa gorda. A ativação de PPARY por rosiglitazona aumenta a quantidade de tecido adiposo subcutâneo, sem entretanto alterar a massa de tecido adiposo epididimal (FESTUCCIA et al., 2009). A ativação deste fator de transcrição pelo óleo de peixe no TAI poderia justificar a massa aumentada deste tecido. Outros mecanismos devem atuar nos animais do grupo HFO onde este efeito não foi observado. O estímulo da $\beta$-oxidação no fígado discutida adiante é um bom argumento para explicar a proteção ao aumento da massa de TAI no grupo HFO.

O óleo de peixe promoveu decréscimo nos valores de glicemia e insulinemia basal nos grupos NFO e HFO, indicando aumento da sensibilidade à insulina. Entretanto, ao se testar a sensibilidade a este hormônio através do ITT e pela 
determinação da captação de 2-desoxi-glicose e síntese de glicogênio no músculo sóleo isolado, não foi detectada alteração na sensibilidade à insulina entre os grupos. Os efeitos do óleo de peixe na homeostasia glicêmica foram mais evidentes quando a tolerância à glicose foi avaliada através do GTT. Neste teste, onde os animais são desafiados com uma sobrecarga de glicose, os camundongos tratados com óleo de peixe apresentaram menor área sob a curva glicêmica que aqueles tratados com dietas preparadas a partir de banha. Este resultado indica que pelo menos dois mecanismos podem estar ocorrendo juntos ou separados: a gliconeogênese pode ter sido inibida de forma mais eficiente em resposta à secreção de insulina decorrente do aumento da glicemia, ou a secreção de insulina frente ao desafio de glicose foi maior nos grupos NFO e HFO em comparação a NL e HL, induzindo maior captação de glicose nos tecidos periféricos.

Além de promover diminuição da insulinemia basal e da concentração plasmática de glicose nas condições basal e durante o GTT, o óleo de peixe também induziu efeitos importantes no metabolismo de lipídios. Apesar deste ter sido um dos grupos que receberam dieta hiperlipídica, o HFO foi o que apresentou os menores valores de colesterol total, triacilgliceróis e NEFA plasmáticos. Um dos principais efeitos do óleo de peixe, conhecido desde a década de 70, é a modulação da concentração de lipídios circulantes (DYERBERG; BANG; HJORNE, 1975). A diminuição de triacilgliceróis no plasma foi descrita por diferentes grupos, sendo um dos efeitos atribuídos ao óleo de peixe mais conhecidos.

No presente estudo, os animais tratados com óleo de peixe, especialmente aqueles do grupo NFO, apresentaram menor conteúdo hepático de triacilgliceróis e diacilgliceróis, apesar de não terem sido detectadas diferenças no conteúdo de triacilgliceróis no músculo gastrocnêmio. O conteúdo reduzido de lipídios no fígado é considerado preditor de melhor controle glicêmico. Vários autores relacionam a prevenção da resistência à insulina pelos PUFA n-3 a esta diminuição dos lipídios circulantes e do conteúdo de lipídios em tecidos que não são estoques característicos de triacilgliceróis, como o fígado e músculo esquelético (KRAEGEN; COONEY; THOMPSON, 2001; SIMONCIKOVA, et al., 2002).

A ativação de PPARs por EPA e DHA, encontrados em altas concentrações no óleo de alguns peixes, é bem conhecida e foi descrita por diferentes grupos (CHAMBRIER et al., 2002; NAKATANI et al., 2003). Os efeitos observados neste 
estudo e atribuídos ao óleo de peixe são muito similares àqueles dos ativadores de PPAR e incluem: aumento da atividade de enzimas envolvidas na oxidação de AG, inibição da síntese de enzimas lipogênicas e alteração da preferência pelo substrato energético utilizado no músculo, privilegiando a oxidação de $A G$ em detrimento de glicose (MASCARO et al., 1998; NAKATANI et al., 2003; HEGARTY et al., 2004; BRUNMAIR et al., 2006).

A estimulação da $\beta$-oxidação foi observada nos peroxissomos hepáticos, mas não no músculo esquelético. Além de não ter sido detectadas alterações na oxidação de AG no músculo esquelético, o conteúdo de triacilgliceróis neste tecido foi semelhante entre os grupos e não houve diferenças nas respostas à insulina. $O$ fígado parece ser o órgão onde os efeitos da ativação do PPAR na modulação do metabolismo lipídico são mais evidentes. Vários grupos descreveram aumento do número e função dos peroxissomos no fígado, mas não no músculo esquelético de camundongos tratados com óleo de peixe (WILLUMSEN et al., 1993; NESCHEN et al., 2002). O aumento da razão de AG n-3/n-6 estimula a $\beta$-oxidação e a atividade da ACO - a primeira enzima da $\beta$-oxidação peroxissomal de AG no fígado de ratos. Estes efeitos foram também observados em animais tratados com bezafibrato, um agonista de PPAR, mas não foram reproduzidos na $\beta$-oxidação mitocondrial (VAMECQ et al., 1993; TAKEUCHI et al., 2008). A relação entre a ativação de PPAR e a indução da $\beta$-oxidação peroxissomal é vista por alguns autores como um mecanismo de proteção contra o desenvolvimento de doenças relacionadas à alta ingestão de lipídios (REDDY e HASHIMOTO, 2001).

Tendo em conta os efeitos clássicos dos agonistas de PPAR e o fenótipo observado nos animais do grupo HFO (menor peso corporal, menor acúmulo de tecido adiposo, concentrações de lipídios plasmáticos reduzidas e menor acúmulo de lipídios no fígado), seria possível supor que o óleo de peixe induziu aumento da oxidação de lipídios. Entretanto, foi surpreendente o menor consumo de $\mathrm{O}_{2}$ nos grupos tratados com óleo de peixe, verificado através da calorimetria indireta. Este decréscimo no consumo de $\mathrm{O}_{2}$ parece ser um efeito direto do óleo de peixe e também foi reportado em atletas suplementados com PUFA n-3 (PEOPLES e MCLENNAN, 2010; PEOPLES et al., 2008).

Os resultados da oxidação de ácido palmítico em homogenatos de fígado corroboram as observações quanto a produção de $\mathrm{CO}_{2}$ in vivo. Apesar de não ter 
sido observado aumento na oxidação total de palmitato, maior produção de ASM a partir deste AG foi observada no fígado dos camundongos do grupo HFO, indicando aumento na $\beta$-oxidação deste. A elevação na atividade das enzimas ACO, MCAD e BHAD, no grupo HFO, neste tecido é mais uma evidência de que o aumento na oxidação parcial do ácido palmítico no fígado foi devido ao maior fluxo de metabólitos na $\beta$-oxidação. A atividade mais elevada da $A C O$, enzima encontrada exclusivamente nos peroxissomos, e o conteúdo aumentado da PMP-70, um marcador de membrana peroxissomal, no fígado dos camundongos deste grupo reforçam a idéia de que a função peroxissomal está estimulada no grupo HFO.

Tomadas em conjunto, estas observações justificam a baixa taxa de consumo de $\mathrm{O}_{2}$ pelos camundongos do grupo $\mathrm{HFO}$, uma vez que a $\beta$-oxidação peroxissomal consome menos oxigênio que o mesmo processo quando ocorre nas mitocôndrias.

A evidência mais importante do envolvimento do PPAR e dos peroxissomos no aumento da oxidação parcial de ácido palmítico no fígado foi obtida com a realização do mesmo experimento utilizando-se hepatócitos isolados de camundongos tratados com um agonista sintético de PPAR - Wy,14-643. Nos hepatócitos isolados dos animais tratados com esta droga, observou-se a mesma inibição da produção de $\mathrm{CO}_{2}$ e aumento na produção de ASM verificados em homogenatos de fígado dos camundongos do grupo HFO.

O efeito do óleo de peixe na oxidação do ácido palmítico em homogenatos de fígado é atribuído aos peroxissomos e não às mitocôndrias pois não foram observadas diferenças no conteúdo das proteínas da cadeia de transporte de elétrons (CTE) e CPT-1. Além disso, a atividade de enzimas mitocondriais envolvidas no ciclo de Krebs (CS e SDH) não apresentou modulação positiva, apenas discreta diminuição na atividade da CS no fígado do grupo HFO.

A importância dos peroxissomos como efetores da modulação do metabolismo de carboidratos e lipídios induzida pelo óleo de peixe, é melhor compreendida se forem considerados alguns aspectos da fisiologia destas organelas, citados a seguir:

Ativadores de PPAR, como PUFA n-3, são indutores da proliferação de peroxissomos. Este efeito foi relatado como uma das primeiras ações dos agonistas de PPAR (ISSEMANN e GREEN, 1990);

A $\beta$-oxidação peroxissomal gera menos energia a partir da mesma quantidade de $A G$ oxidados, quando comparada à $\beta$-oxidação mitocondrial. Esta geração 
ineficiente de energia é causada em parte pela ausência de CTE nos peroxissomos. Dessa forma, a flavoproteína ACO transfere os elétrons que retira do acil-CoA para o oxigênio molecular e os elétrons coletados pelo $\mathrm{FADH}_{2}$ da $\mathrm{ACO}$ não são usados para a geração de ATP (WANDERS et al., 2001).

A $\beta$-oxidação de PUFA demanda uma reação extra catalisada pela 2,4-dienoilCoA redutase que é dependente de NADPH. Esta etapa não é necessária durante a oxidação de $A G$ saturados e isto implica em consumo de equivalentes redutores durante a oxidação de PUFA.

Finalmente, as moléculas de acetil CoA geradas a partir dos AG pela $\beta$ oxidação podem ser direcionadas para o ciclo de Krebs na mitocôndria, sendo oxidadas à $\mathrm{CO}_{2}$, reduzindo flavoproteínas e proteínas que contenham o co-fator nicotinamida. Na CTE, o transporte de elétrons doados pelos nucleotídeos reduzidos no ciclo de Krebs e $\beta$-oxidação gera um gradiente eletroquímico que é acoplado à produção de ATP e redução de oxigênio à água. Este processo implica no consumo de $\mathrm{O}_{2}$ e produção de $\mathrm{CO}_{2}$. Entretanto, há controvérsias a respeito do destino das moléculas de acetil CoA produzidas na $\beta$-oxidação peroxissomal. Bian et al. (2005) não detectaram transferência de acetil CoA dos peroxissomos para as mitocôndrias em coração perfundido de ratos. Se pelo menos parte do acetil CoA gerado nos peroxissomos não for transferida para as mitocôndrias no fígado dos animais do grupo $\mathrm{HFO}$, menor consumo de $\mathrm{O}_{2}$ e produção de $\mathrm{CO}_{2}$ devem ser esperados, diminuindo a eficiência da geração de energia por este processo. Esta hipótese justifica os resultados dos ensaios de oxidação de ácido palmítico em homogenatos de fígado e das medidas de calorimetria indireta.

Para compensar a menor eficiência na geração de energia induzida pela proliferação de peroxissomos, é de se esperar que mais AG sejam direcionados à oxidação. Esta possibilidade explicaria porque camundongos do grupo HFO apresentaram menor peso corporal, adiposidade, consumo de $\mathrm{O}_{2}$ e geração de $\mathrm{CO}_{2}$.

Apenas para ilustrar o menor consumo de oxigênio e geração de energia a partira da oxidação de PUFA n-3, a Tabela 4 apresenta o cálculo do número de moléculas de ATP geradas e de $\mathrm{O}_{2}$ consumidas pela oxidação de $1 \mathrm{~g}$ de ácido esteárico (C18:0) e DHA (C22:6n3), considerando hipoteticamente que o primeiro seria completamente oxidado nas mitocôndrias e o segundo oxidado em peroxissomos e mitocôndrias. A quantidade de ATP necessária para ativar as 
moléculas de $A G$ através da esterificação destas à coenzima $A$ foi desconsiderada. Para este cálculo, assumiu-se que o docosa-hexanoil CoA (com 22 átomos de carbono) foi oxidado nos peroxissomos até ser encurtado a 4 átomos de carbono, que tem sua metabolização pela $\beta$-oxidação peroxissomal impedida pelo tamanho de cadeia hidrocarbônica e que o butiril CoA gerado foi transferido para a mitocôndria. Assumiu-se também que as moléculas de NADH geradas nos peroxissomos, durante a oxidação de DHA, não transferiram seus elétrons para a CTE mitocondrial. A produção de ATP foi calculada com uma razão de 2,5 para cada molécula de $\mathrm{NADH}$ e 1,5 para cada molécula de $\mathrm{FADH}_{2}$ que doaram elétrons para a CTE. O cálculo do consumo de oxigênio foi estimado considerando-se a razão de 3,25 moléculas de ATP produzidas para cada molécula de $\mathrm{O}_{2}$ consumido (LEMASTERS, 1984).

Tabela 4 - Consumo de oxigênio pela oxidação de ácidos graxos. Cálculo do consumo de oxigênio e produção de ATP a partir da oxidação de ácido esteárico e DHA, considerando o envolvimento da $\beta$-oxidação peroxissomal e mitocondrial.

\begin{tabular}{|c|c|c|}
\hline & DHA & $\begin{array}{c}\text { Ácido } \\
\text { Esteárico }\end{array}$ \\
\hline Quantidade (g) & 1,00 & 1,00 \\
\hline Número de moléculas (PM DHA = 328.49 /ác. esteárico $=284.48$ ) & $1,83 E+21$ & $2,12 E+21$ \\
\hline Ciclos de $\beta$-oxidação realizados nas mitocôndrias & 1,00 & 8,00 \\
\hline Ciclos de $\beta$-oxidação realizados nos peroxissomos & 9,00 & 0,00 \\
\hline Moléculas de acetil CoA produzidas & $2,02 E+22$ & $1,90 E+22$ \\
\hline Moléculas de acetil CoA produzidas na mitocôndria & $3,67 E+21$ & $1,90 E+22$ \\
\hline Moléculas de NADH produzidas na $\beta$-oxidação & $1,83 E+22$ & $1,69 E+22$ \\
\hline Moléculas de NADPH consumidas na $\beta$-oxidação & $-5,50 E+21$ & $0,00 \mathrm{E}+00$ \\
\hline Moléculas de NADH produzidas no Ciclo de Krebs & $1,10 \mathrm{E}+22$ & $5,71 \mathrm{E}+22$ \\
\hline Equivalentes redutores gerados (nucleotídios nicotinamídicos) & $2,38 E+22$ & $7,41 E+22$ \\
\hline Moléculas de $\mathrm{FADH}_{2}$ produzidas na $\beta$-oxidação & $1,83 \mathrm{E}+21$ & $1,69 \mathrm{E}+22$ \\
\hline Moléculas de $\mathrm{FADH}_{2}$ produzidas no Ciclo de Krebs & $3,67 \mathrm{E}+21$ & $1,90 \mathrm{E}+22$ \\
\hline Equivalentes redutores gerados (nucleotídios flavínicos) & $5,50 E+21$ & $3,60 E+22$ \\
\hline ATP gerado (2,5 ATP para cada NADH e 1,5 ATP para cada FADH 2 ) & $4,95 E+22$ & $2,01 E+23$ \\
\hline Moléculas de oxigênio utilizadas $\left(\mathrm{ATP} / \mathrm{O}_{2}=3,25\right)$ & $1,52 E+22$ & $6,19 E+22$ \\
\hline Volume de oxigênio consumido (I) & 0,57 & 2,30 \\
\hline
\end{tabular}


A capacidade da $\beta$-oxidação peroxissomal pode variar entre 10 e $30 \%$ daquela observada na $\beta$-oxidação mitocondrial (NEAT et al., 1981), dependendo do substrato utilizado e por isso a sua importância não deve ser subestimada. A ineficiência na geração de energia pela $\beta$-oxidação peroxissomal é maior quando os substratos oxidados são PUFA n-3, pelo fato desta ser a única via possível de $\beta$-oxidação destas moléculas, e pelos fatores mencionados acima. Entretanto, com o aumento no número de peroxissomos, outros AG normalmente oxidados pela mitocôndria podem passar a ser metabolizados nos peroxissomos, de maneira energeticamente ineficiente. Discutindo sobre os efeitos de um ativador de PPAR, Hegarty et al. (2004) relatam aumento na quantidade de acil CoA de cadeia longa paralelamente à diminuição de triacilgliceróis e aumento da população de peroxissomos no fígado de camundongos tratados com uma dieta hiperlipídica. De acordo com os autores, o aumento de acil CoA de cadeia longa não implicou no desenvolvimento da resistência à insulina pelo fato destes metabólitos estarem confinados no interior dos peroxissomos. Esta é uma evidência importante de que AG que normalmente seriam oxidados pelas mitocôndrias podem ser metabolizados pelos peroxissomos quando o número destas organelas encontra-se aumentado.

Os esqueletos de carbono que foram ingeridos como $A G$ e que não foram estocados no tecido adiposo, nem oxidados a $\mathrm{CO}_{2}$, devem ser direcionados para a geração de outros metabólitos. Como importantes passos da via de síntese de ácidos biliares ocorrem nos peroxissomos (MONTE et al., 2009) e considerando-se o aumento da atividade peroxissomal no grupo HFO, é possível que estes esqueletos de carbono tenham sido incorporados em ácidos biliares ou esteróis, seus precurssores.

Os ácidos biliares tem efeitos na modulação do metabolismo energético e podem proteger contra doenças associadas à obesidade como diabetes tipo 2. Seus efeitos no metabolismo de carboidratos e lipídios hepáticos se dá através do receptor Farnesoid X Receptor (FXR) (CLAUDEL; STAELS; KUIPERS, 2005). Estas moléculas podem prevenir a esteatose hepática induzida por frutose (VOLYNETS et al., 2005) e diminuir as concentrações de triacilgliceróis plasmáticos (SINAL et al., 2000; CLAUDEL et al., 2003). Além dos efeitos hepáticos via FXR, os ácidos biliares promovem ações sistêmicas pela ativação do TGR5/Gpbar-1, um receptor acoplado 
à proteína $\mathrm{G}$, causando aumento do consumo energético no músculo esquelético e tecido adiposo marrom (TRAUNER et al., 2010).

Os efeitos do óleo de peixe na diminuição da glicemia e insulinemia basais e na área sob a curva glicêmica durante o GTT estão associados à redução no conteúdo de lipídios circulantes e em tecidos alvo da insulina. $\mathrm{O}$ aumento do número de peroxissomos e da $\beta$-oxidação peroxissomal devem ser responsáveis pelo menor acúmulo de lipídios no fígado. A ativação do PPAR está relacionada ao estímulo do metabolismo peroxissomal, que pode aumentar a produção de ácidos biliares e dessa forma criar uma via alternativa para as moléculas geradas na $\beta$-oxidação peroxissomal a partir de AG. Este mecanismo provê uma explicação plausível para a redução na massa corporal e nos depósitos de tecido adiposo, apesar do aumento na ingestão energética e diminuição no consumo de $\mathrm{O}_{2}$ observados no grupo HFO. Esta hipótese, ilustrada na Figura 24, permanece em estudo, mas ressalta a importância dos peroxissomos como mediadores dos efeitos dos PUFA n-3. Pela sua importância no metabolismo de lipídios, estas organelas são bons alvos para o desenvolvimento de terapias visando o tratamento da obesidade e doenças associadas. 

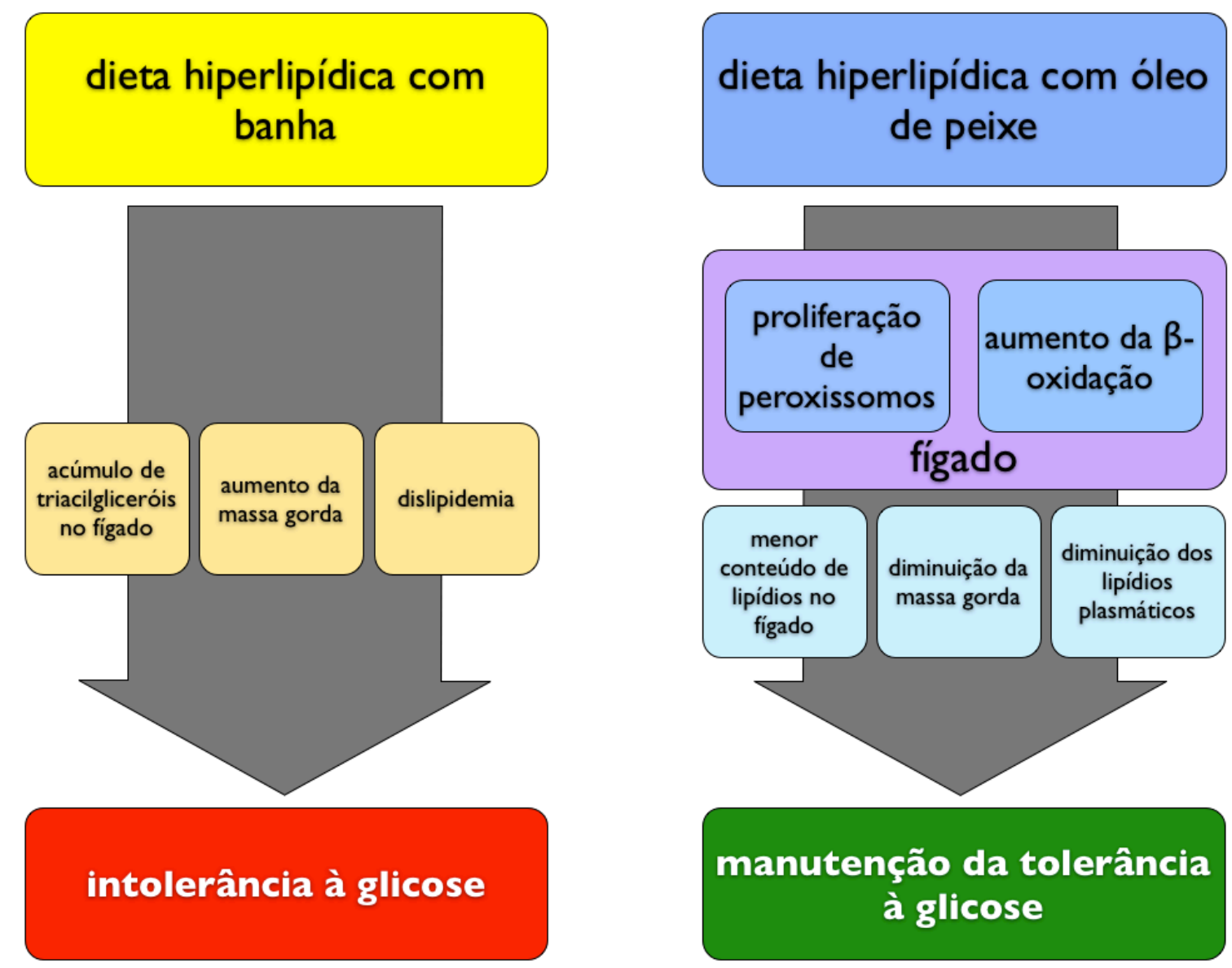

Figura 24 - Mecanismo de ação dos PUFA n-3 na preservação da tolerância à glicose. Mecanismo proposto para a ação dos PUFA n-3 no metabolismo de lipídios e preservação da tolerância à glicose. 


\section{Conclusão}

Os resultados apresentados ressaltam a importância dos peroxissomos como efetores da modulação do metabolismo de lipídios pelo óleo de peixe no fígado de camundongos. Acreditamos que, pela alteração nas taxas de oxidação de AG, diminuição do acúmulo de lipídios no fígado e redução da massa de tecido adiposo, os PUFA n-3 podem prevenir o desenvolvimento da resistência à insulina.

Através de evidências obtidas in vivo e in vitro, mostramos pela primeira vez que o óleo de peixe pode aumentar a oxidação parcial de AG no fígado apesar de diminuir a sua oxidação total e que isto implica em menor consumo de oxigênio. As observações apresentadas reforçam a proposição de que os peroxissomos, e não as mitocôndrias, são os principais alvos de ação dos PUFA n-3, pelo menos no período de tratamento avaliado. Além disso, fica evidenciada por estes resultados, a importância do fígado e não do músculo nestas ações.

Estudos adicionais são necessários para identificar o destino das moléculas de acetil-CoA geradas a partir dos $A G$ que sofrem $\beta$-oxidação peroxissomal. $O$ esclarecimento desta via certamente contribuirá no avanço do conhecimento de mecanismos protetores contra a obesidade e o diabetes tipo 2 . 


\section{Referências *}

AHMAD, F.; AZEVEDO, J. L.; CORTRIGHT, R.; DOHM, G. L.; GOLDSTEIN, B. J. Alterations in skeletal muscle protein-tyrosine phosphatase activity and expression in insulin-resistant human obesity and diabetes. J. Clin. Invest., v. 100, n. 2, p. 449-458, 1997.

ALESSI, D. R.; ANDJELKOVIC, M.; CAUDWELL, B.; CRON, P.; MORRICE, N.; COHEN, P.; HEMMINGS, B. A. Mechanism of activation of protein kinase $b$ by insulin and igf-1. Embo J., v. 15, n. 23, p. 6541-6551, 1996.

ALESSI, D. R.; DOWNES, C. P. The role of pi 3-kinase in insulin action. Biochim Biophys. Acta, v. 1436, n. 1-2, p. 151-164, 1998.

AMOS, A. F.; MCCARTY, D. J.; ZIMMET, P. The rising global burden of diabetes and its complications: Estimates and projections to the year 2010. Diabet. Med., v. 14, p. S1-85, 1997. Suppl 5.

AMRI, E. Z.; AILHAUD, G.; GRIMALDI, P. A. Fatty acids as signal transducing molecules: Involvement in the differentiation of preadipose to adipose cells. J. Lipid Res., v. 35, n. 5, p. 930-937, 1994.

ASANO, T.; KANDA, A.; KATAGIRI, H.; NAWANO, M.; OGIHARA, T.; INUKAI, K.; ANAI, M.; FUKUSHIMA, Y.; YAZAKI, Y.; KIKUCHI, M.; HOOSHMAND-RAD, R.; HELDIN, C. H.; OKA, Y.; FUNAKI, M. P110beta is up-regulated during differentiation of $3 \mathrm{t} 3-11$ cells and contributes to the highly insulin-responsive glucose transport activity. J. Biol. Chem., v. 275, n. 23, p. 17671-17676, 2000.

ASHCROFT, F. M.; GRIBBLE, F. M. Atp-sensitive $k+$ channels and insulin secretion: Their role in health and disease. Diabetologia, v. 42, n. 8, p. 903-919, 1999.

BACKER, J. M.; MYERS, M. G., JR.; SHOELSON, S. E.; CHIN, D. J.; SUN, X. J.; MIRALPEIX, M.; HU, P.; MARGOLIS, B.; SKOLNIK, E. Y.; SCHLESSINGER, J.; ET AL. Phosphatidylinositol 3'-kinase is activated by association with irs-1 during insulin stimulation. Embo J., v. 11, n. 9, p. 3469-3479, 1992.

* De acordo com: ASSOCIAÇÃO BRASILEIRA DE NORMAS TÉCNICAS. NBR 6023: informação e documentação: referências: elaboração. Rio de Janeiro, 2002. 
BALLOTTI, R.; SCIMECA, J. C.; KOWALSKI, A.; VAN OBBERGHEN, E. Antiphosphotyrosine antibodies modulate insulin receptor kinase activity and insulin action. Cell. Signal., v. 1, n. 2, p. 195-204, 1989.

BANG, H. O.; DYERBERG, J.; SINCLAIR, H. M. The composition of the eskimo food in north western greenland. Am. J. Clin. Nutr., v. 33, n. 12, p. 2657-2661, 1980.

BARON, V.; VAN OBBERGHEN, E. [mechanism of insulin action]. C. $R$. Seances. Soc Biol. Fil., v. 189, n. 1, p. 25-41, 1995.

BELZUNG, F.; RACLOT, T.; GROSCOLAS, R. Fish oil n-3 fatty acids selectively limit the hypertrophy of abdominal fat depots in growing rats fed high-fat diets. $A m$. J .Physiol., v. 264, n. 6, pt 2, p. R1111-R1118, 1993.

BIAN, F.; KASUMOV, T.; THOMAS, K. R.; JOBBINS, K. A.; DAVID, F.; MINKLER, P. E.; HOPPEL, C. L.; BRUNENGRABER, H. Peroxisomal and mitochondrial oxidation of fatty acids in the heart, assessed from the 13c labeling of malonyl-CoA and the acetyl moiety of citrate. J. Biol. Chem., v. 280, n. 10, p. 9265-9271, 2005.

BISHOP-BAILEY, D.; WRAY, J. Peroxisome proliferator-activated receptors: A critical review on endogenous pathways for ligand generation. Prostaglandins Other Lipid Mediat., v. 71, n. 1-2, p. 1-22, 2003.

BJERREGAARD, P.; PEDERSEN, H. S.; MULVAD, G. The associations of a marine diet with plasma lipids, blood glucose, blood pressure and obesity among the inuit in greenland. Eur. J. Clin. Nutr., v. 54, n. 9, p. 732-737, 2000.

BODEN, G. Effects of free fatty acids (ffa) on glucose metabolism: Significance for insulin resistance and type 2 diabetes. Exp. Clin. Endocrinol. Diabetes, v. 111, n. 3, p. 121-124, 2003.

Role of fatty acids in the pathogenesis of insulin resistance and niddm. Diabetes, v. 46, n. 1, p. 3-10, 1997.

BOLLAG, G. E.; ROTH, R. A.; BEAUDOIN, J.; MOCHLY-ROSEN, D.; KOSHLAND, D. E., JR. Protein kinase $c$ directly phosphorylates the insulin receptor in vitro and reduces its protein-tyrosine kinase activity. Proc. Natl. Acad. Sci. U S A, v. 83, n. 16, p. 5822-5824, 1986. 
BROWN, F. R., 3RD; MCADAMS, A. J.; CUMMINS, J. W.; KONKOL, R.; SINGH, I.; MOSER, A. B.; MOSER, H. W. Cerebro-hepato-renal (zellweger) syndrome and neonatal adrenoleukodystrophy: Similarities in phenotype and accumulation of very long chain fatty acids. Johns Hopkins Med. J., v. 151, n. 6, p. 344-351, 1982.

BRUN, S.; CARMONA, M. C.; MAMPEL, T.; VINAS, O.; GIRALT, M.; IGLESIAS, R.; VILLARROYA, F. Uncoupling protein-3 gene expression in skeletal muscle during development is regulated by nutritional factors that alter circulating non-esterified fatty acids. FEBS Lett., v. 453, n. 1-2, p. 205-209, 1999.

BRUNMAIR, B.; STANIEK, K.; DORIG, J.; SZOCS, Z.; STADLBAUER, K.; MARIAN, V.; GRAS, F.; ANDERWALD, C.; NOHL, H.; WALDHAUSL, W.; FURNSINN, C. Activation of ppar-delta in isolated rat skeletal muscle switches fuel preference from glucose to fatty acids. Diabetologia, v. 49, n. 11, p. 2713-2722, 2006.

BURR, G. O. A. B., M. A new deficiency disease produced by the rigid exclusion of fat from the diet. The Journal of Biological Chemistry, v. 2, 1929.

CARLSEN, J.; CHRISTIANSEN, K.; VINTEN, J. Insulin stimulated glycogen synthesis in isolated rat hepatocytes: Effect of protein kinase inhibitors. Cell. Signal., v. 9, n. 6, p. 447-450, 1997.

CHA, B. S.; CIARALDI, T. P.; CARTER, L.; NIKOULINA, S. E.; MUDALIAR, S.; MUKHERJEE, R.; PATERNITI, J. R., JR.; HENRY, R. R. Peroxisome proliferatoractivated receptor (ppar) gamma and retinoid $\mathrm{x}$ receptor (rxr) agonists have complementary effects on glucose and lipid metabolism in human skeletal muscle. Diabetologia, v. 44, n. 4, p. 444-452, 2001.

CHAMBRIER, C.; BASTARD, J. P.; RIEUSSET, J.; CHEVILLOTTE, E.; BONNEFONT-ROUSSELOT, D.; THEROND, P.; HAINQUE, B.; RIOU, J. P.; LAVILLE, M.; VIDAL, H. Eicosapentaenoic acid induces mrna expression of peroxisome proliferator-activated receptor gamma. Obes. Res., v. 10, n. 6, p. 518-525, 2002.

CHANG, Y. W.; TRAUGH, J. A. Insulin stimulation of phosphorylation of elongation factor 1 (eef-1) enhances elongation activity. Eur. J. Biochem., v. 251, n. 1-2, p. 201-207, 1998.

CHAVEZ, J. A.; SUMMERS, S. A. Characterizing the effects of saturated fatty acids on insulin signaling and ceramide and diacylglycerol accumulation in 3t3-l1 adipocytes and c2c12 myotubes. Arch. Biochem. Biophys., v. 419, n. 2, p. 101-109, 2003. 
CHEATHAM, B.; VLAHOS, C. J.; CHEATHAM, L.; WANG, L.; BLENIS, J.; KAHN, C. $R$. Phosphatidylinositol 3-kinase activation is required for insulin stimulation of pp70 s6 kinase, DNA synthesis, and glucose transporter translocation. Mol. Cell. Biol., v. 14, n. 7, p. 4902-4911, 1994.

CHEVILLOTTE, E.; RIEUSSET, J.; ROQUES, M.; DESAGE, M.; VIDAL, H. The regulation of uncoupling protein-2 gene expression by omega- 6 polyunsaturated fatty acids in human skeletal muscle cells involves multiple pathways, including the nuclear receptor peroxisome proliferator-activated receptor beta. J. Biol. Chem., v. 276, n. 14, p. 10853-10860, 2001.

CHICCO, A.; D'ALESSANDRO, M. E.; KARABATAS, L.; GUTMAN, R.; LOMBARDO, Y. B. Effect of moderate levels of dietary fish oil on insulin secretion and sensitivity, and pancreas insulin content in normal rats. Ann. Nutr. Metab., v. 40, n. 2, p. 61-70, 1996.

CLAUDEL, T.; INOUE, Y.; BARBIER, O.; DURAN-SANDOVAL, D.; KOSYKH, V.; FRUCHART, J.; FRUCHART, J. C.; GONZALEZ, F. J.; STAELS, B. Farnesoid x receptor agonists suppress hepatic apolipoprotein ciii expression. Gastroenterology, v. 125, n. 2, p. 544-555, 2003.

CLAUDEL, T.; STAELS, B.; KUIPERS, F. The farnesoid $\mathrm{x}$ receptor: A molecular link between bile acid and lipid and glucose metabolism. Arterioscler. Thromb. Vasc. Biol., v. 25, n. 10, p. 2020-2030, 2005.

COHEN, A. W.; RAZANI, B.; WANG, X. B.; COMBS, T. P.; WILLIAMS, T. M.; SCHERER, P. E.; LISANTI, M. P. Caveolin-1-deficient mice show insulin resistance and defective insulin receptor protein expression in adipose tissue. Am. J. Physiol. Cell. Physiol., v. 285, n. 1, p. C222-235, 2003.

COLEMAN, R. A.; LEWIN, T. M.; MUOIO, D. M. Physiological and nutritional regulation of enzymes of triacylglycerol synthesis. Annu. Rev. Nutr., v. 20, p. 77-103, 2000.

COOPER, T. G.; BEEVERS, H. Beta oxidation in glyoxysomes from castor bean endosperm. J. Biol. Chem., v. 244, n. 13, p. 3514-3520, 1969.

COX, M, NELSON, D. L. Lehninger principles of biochemistry. 4th ed. New York: W. H. Freeman, 2005. 
CUENDET, G. S.; LOTEN, E. G.; JEANRENAUD, B.; RENOLD, A. E. Decreased basal, noninsulin-stimulated glucose uptake and metabolism by skeletal soleus muscle isolated from obese-hyperglycemic (ob/ob) mice. J. Clin. Invest., v. 58, n. 5, p. 1078-1088, 1976.

DAS, U. N.; FAMS. Long-chain polyunsaturated fatty acids in the growth and development of the brain and memory. Nutrition, v. 19, n. 1, p. 62-65, 2003.

DE DUVE, C.; BAUDHUIN, P. Peroxisomes (microbodies and related particles). Physiol. Rev., v. 46, n. 2, p. 323-357, 1966.

DOBRZYN, A.; GORSKI, J. Effect of acute exercise on the content of free sphinganine and sphingosine in different skeletal muscle types of the rat. Horm. Metab. Res., v. 34, n. 9, p. 523-529, 2002.

DONG, L. Q.; ZHANG, R. B.; LANGLAIS, P.; HE, H.; CLARK, M.; ZHU, L.; LIU, F. Primary structure, tissue distribution, and expression of mouse phosphoinositidedependent protein kinase-1, a protein kinase that phosphorylates and activates protein kinase czeta. J. Biol. Chem., v. 274, n. 12, p. 8117-8122, 1999.

DRESNER, A.; LAURENT, D.; MARCUCCI, M.; GRIFFIN, M. E.; DUFOUR, S.; CLINE, G. W.; SLEZAK, L. A.; ANDERSEN, D. K.; HUNDAL, R. S.; ROTHMAN, D. L.; PETERSEN, K. F.; SHULMAN, G. I. Effects of free fatty acids on glucose transport and irs-1-associated phosphatidylinositol 3-kinase activity. J. Clin. Invest., v. 103, n. 2, p. 253-259, 1999.

DYERBERG, J.; BANG, H. O.; HJORNE, N. Fatty acid composition of the plasma lipids in greenland eskimos. Am. J. Clin. Nutr., v. 28, n. 9, p. 958-966, 1975.

FESKENS, E. J.; BOWLES, C. H.; KROMHOUT, D. Inverse association between fish intake and risk of glucose intolerance in normoglycemic elderly men and women. Diabetes Care., v. 14, n. 11, p. 935-941, 1991.

FESTUCCIA, W. T.; BLANCHARD, P. G.; TURCOTTE, V.; LAPLANTE, M.; SARIAHMETOGLU, M.; BRINDLEY, D. N.; DESHAIES, Y. Depot-specific effects of the ppargamma agonist rosiglitazone on adipose tissue glucose uptake and metabolism. J. Lipid Res., v. 50, n. 6, p. 1185-1194, 2009.

FOLCH, J.; LEES, M.; SLOANE STANLEY, G. H. A simple method for the isolation and purification of total lipides from animal tissues. J. Biol. Chem., v. 226, n. 1, p. 497-509, 1957. 
FRANK, P. G.; GALBIATI, F.; VOLONTE, D.; RAZANI, B.; COHEN, D. E.; MARCEL, Y. L.; LISANTI, M. P. Influence of caveolin-1 on cellular cholesterol efflux mediated by high-density lipoproteins. Am. J. Physiol. Cell. Physiol., v. 280, n. 5, p. C1204-1214, 2001.

GEARING, K. L.; GOTTLICHER, M.; TEBOUL, M.; WIDMARK, E.; GUSTAFSSON, $\mathrm{J}$. A. Interaction of the peroxisome-proliferator-activated receptor and retinoid $\mathrm{x}$ receptor. Proc. Natl. Acad. Sci. U S A, v. 90, n. 4, p. 1440-1444, 1993.

GHAFOORUNISSA; IBRAHIM, A.; RAJKUMAR, L.; ACHARYA, V. Dietary (n-3) long chain polyunsaturated fatty acids prevent sucrose-induced insulin resistance in rats. J. Nutr., v. 135, n. 11, p. 2634-2638, 2005.

GOMEZ-MUNOZ, A. Modulation of cell signalling by ceramides. Biochim. Biophys. Acta, v. 1391, n. 1, p. 92-109, 1998.

GORDON, R. S., JR. Metabolism of serum-free fatty acids. Fed. Proc., v. 19, p. 120-121, 1960. (Suppl 5).

GOTTLICHER, M.; WIDMARK, E.; LI, Q.; GUSTAFSSON, J. A. Fatty acids activate a chimera of the clofibric acid-activated receptor and the glucocorticoid receptor. Proc. Natl. Acad. Sci. U S A, v. 89, n. 10, p. 4653-4657, 1992.

GRIFFIN, M. E.; MARCUCCI, M. J.; CLINE, G. W.; BELL, K.; BARUCCI, N.; LEE, D.; GOODYEAR, L. J.; KRAEGEN, E. W.; WHITE, M. F.; SHULMAN, G. I. Free fatty acid-induced insulin resistance is associated with activation of protein kinase $c$ theta and alterations in the insulin signaling cascade. Diabetes, v. 48, n. 6, p. 1270-1274, 1999.

GUSTAVSSON, J.; PARPAL, S.; KARLSSON, M.; RAMSING, C.; THORN, H.; BORG, M.; LINDROTH, M.; PETERSON, K. H.; MAGNUSSON, K. E.; STRALFORS, P. Localization of the insulin receptor in caveolae of adipocyte plasma membrane. Faseb J., v. 13, n. 14, p. 1961-1971, 1999.

HAJRA, A. K.; BURKE, C. L.; JONES, C. L. Subcellular localization of acyl coenzyme a: Dihydroxyacetone phosphate acyltransferase in rat liver peroxisomes (microbodies). J. Biol. Chem., v. 254, n. 21, p. 10896-10900, 1979.

HEGARTY, B. D.; FURLER, S. M.; OAKES, N. D.; KRAEGEN, E. W.; COONEY, G. J. Peroxisome proliferator-activated receptor (ppar) activation induces tissue-specific effects on fatty acid uptake and metabolism in vivo--a study using the novel 
pparalpha/gamma agonist tesaglitazar. Endocrinology, v. 145, n. 7, p. 3158-3164, 2004.

HESS, R.; STAUBLI, W.; RIESS, W. Nature of the hepatomegalic effect produced by ethyl-chlorophenoxy-isobutyrate in the rat. Nature, v. 208, n. 5013, p. 856-858, 1965.

HIRABARA, S. M.; CARVALHO, C. R. O.; MENDONCA, J. R.; HABER, E. P.; FERNANDES, L. C.; CURI, R. Palmitate acutely raises glycogen synthesis in rat soleus muscle by a mechanism that requires its metabolization (randle cycle). FEBS Lett., v. 541, n. 1-3, p. 109-114, 2003.

HIRABARA, S. M.; SILVEIRA, L. R.; ABDULKADER, F.; CARVALHO, C. R.; PROCOPIO, J.; CURI, R. Time-dependent effects of fatty acids on skeletal muscle metabolism. J. Cell. Physiol., v. 210, n. 1, p. 7-15, 2007.

HOLMAN, R. T. The slow discovery of the importance of omega 3 essential fatty acids in human health. J. Nutr., v. 128, n. 2 Suppl, p. 427S-433S, 1998.

HOLNESS, M. J.; SMITH, N. D.; GREENWOOD, G. K.; SUGDEN, M. C. Acute omega-3 fatty acid enrichment selectively reverses high-saturated fat feedinginduced insulin hypersecretion but does not improve peripheral insulin resistance. Diabetes, v. 53, p. S166-S171, 2004. Suppl 1.

HUNNICUTT, J. W.; HARDY, R. W.; WILLIFORD, J.; MCDONALD, J. M. Saturated fatty acid-induced insulin resistance in rat adipocytes. Diabetes, v. 43, n. 4, p. 540-545, 1994.

ISSEMANN, I.; GREEN, S. Activation of a member of the steroid hormone receptor superfamily by peroxisome proliferators. Nature, v. 347, n. 6294, p. 645-650, 1990.

JONES, P. J.; TOY, B. R.; CHA, M. C. Differential fatty acid accretion in heart, liver and adipose tissues of rats fed beef tallow, fish oil, olive oil and safflower oils at three levels of energy intake. J. Nutr., v. 125, n. 5, p. 1175-1182, 1995.

JUMP, D. B.; CLARKE, S. D. Regulation of gene expression by dietary fat. Annu. Rev. Nutr., v. 19, p. 63-90, 1999.

KAPELLER, R.; CANTLEY, L. C. Phosphatidylinositol 3-kinase. Bioessays, v. 16, n. 8, p. 565-576, 1994. 
KASUGA, M. [mechanism of insulin action--signal transductions after binding to insulin receptor]. Nippon Naibunpi Gakkai Zasshi, v. 69, n. 10, p. 1029-1034, 1993.

KELLER, H.; MAHFOUDI, A.; DREYER, C.; HIHI, A. K.; MEDIN, J.; OZATO, K.; WAHLI, W. Peroxisome proliferator-activated receptors and lipid metabolism. Ann. N Y Acad. Sci., v. 684, p. 157-173, 1993.

KERNER, J.; HOPPEL, C. Fatty acid import into mitochondria. Biochim. Biophys. Acta., v. 1486, n. 1, p. 1-17, 2000.

KERSTEN, S.; DESVERGNE, B.; WAHLI, W. Roles of ppars in health and disease. Nature, v. 405, n. 6785, p. 421-424, 2000.

KIM, J. K.; WI, J. K.; YOUN, J. H. Metabolic impairment precedes insulin resistance in skeletal muscle during high-fat feeding in rats. Diabetes, v. 45, n. 5, p. 651-658, 1996.

KIM, J. Y.; HICKNER, R. C.; CORTRIGHT, R. L.; DOHM, G. L.; HOUMARD, J. A. Lipid oxidation is reduced in obese human skeletal muscle. Am. J. Physiol. Endocrinol. Metab., v. 279, n. 5, p. E1039-E1044, 2000.

KRAEGEN, E. W.; COONEY, G. J.; YE, J.; THOMPSON, A. L. Triglycerides, fatty acids and insulin resistance--hyperinsulinemia. Exp. Clin. Endocrinol. Diabetes, v. 109, n. 4, p. S516-S526, 2001.

KROMANN, N.; GREEN, A. Epidemiological studies in the upernavik district, greenland. Incidence of some chronic diseases 1950-1974. Acta Med. Scand., v. 208, n. 5, p. 401-406, 1980.

KROOK, A.; WHITEHEAD, J. P.; DOBSON, S. P.; GRIFFITHS, M. R.; OUWENS, M.; BAKER, C.; HAYWARD, A. C.; SEN, S. K.; MAASSEN, J. A.; SIDDLE, K.; TAVARE, J. M.; O'RAHILLY, S. Two naturally occurring insulin receptor tyrosine kinase domain mutants provide evidence that phosphoinositide 3-kinase activation alone is not sufficient for the mediation of insulin's metabolic and mitogenic effects. J. Biol. Chem., v. 272, n. 48, p. 30208-30214, 1997.

LAZAROW, P. B.; DE DUVE, C. A fatty acyl-CoA oxidizing system in rat liver peroxisomes; enhancement by clofibrate, a hypolipidemic drug. Proc. Natl. Acad. Sci. U S A, v. 73, n. 6, p. 2043-2046, 1976. 
LEE, H.; WOODMAN, S. E.; ENGELMAN, J. A.; VOLONTE, D.; GALBIATI, F.; KAUFMAN, H. L.; LUBLIN, D. M.; LISANTI, M. P. Palmitoylation of caveolin-1 at a single site (cys-156) controls its coupling to the c-src tyrosine kinase: Targeting of dually acylated molecules (gpi-linked, transmembrane, or cytoplasmic) to caveolae effectively uncouples c-src and caveolin-1 (tyr-14). J. Biol. Chem., v. 276, n. 37, p. 35150-35158, 2001.

LEMASTERS, J. J. The atp-to-oxygen stoichiometries of oxidative phosphorylation by rat liver mitochondria. An analysis of adp-induced oxygen jumps by linear nonequilibrium thermodynamics. J. Biol. Chem., v. 259, n. 21, p. 13123-13130, 1984.

LI, J.; STILLMAN, J. S.; CLORE, J. N.; BLACKARD, W. G. Skeletal muscle lipids and glycogen mask substrate competition (randle cycle). Metabolism, v. 42, n. 4, p. 451-456, 1993.

LICHTENSTEIN, A. H.; SCHWAB, U. S. Relationship of dietary fat to glucose metabolism. Atherosclerosis, v. 150, n. 2, p. 227-243, 2000.

LIU, S.; BARACOS, V. E.; QUINNEY, H. A.; CLANDININ, M. T. Dietary omega-3 and polyunsaturated fatty acids modify fatty acyl composition and insulin binding in skeletal-muscle sarcolemma. Biochem. J., v. 299, pt 3, p. 831-837, 1994.

LOMBARDO, Y. B.; CHICCO, A. G. Effects of dietary polyunsaturated n-3 fatty acids on dyslipidemia and insulin resistance in rodents and humans. A review. J. Nutr .Biochem., v. 17, n. 1, p. 1-13, 2006.

MA, D. W.; SEO, J.; DAVIDSON, L. A.; CALLAWAY, E. S.; FAN, Y. Y.; LUPTON, J. R.; CHAPKIN, R. S. N-3 pufa alter caveolae lipid composition and resident protein localization in mouse colon. Faseb J., v. 18, n. 9, p. 1040-1042, 2004.

MADSEN, L.; PETERSEN, R. K.; KRISTIANSEN, K. Regulation of adipocyte differentiation and function by polyunsaturated fatty acids. Biochim. Biophys. Acta, v. 1740, n. 2, p. 266-286, 2005.

MALLORDY, A.; POIRIER, H.; BESNARD, P.; NIOT, I.; CARLIER, H. Evidence for transcriptional induction of the liver fatty-acid-binding-protein gene by bezafibrate in the small intestine. Eur. J. Biochem., v. 227, n. 3, p. 801-807, 1995.

MASCARO, C.; ACOSTA, E.; ORTIZ, J. A.; MARRERO, P. F.; HEGARDT, F. G.; HARO, D. Control of human muscle-type carnitine palmitoyltransferase i gene transcription by peroxisome proliferator-activated receptor. J. Biol. Chem., v. 273, n. 15 , p. 8560-8563, 1998. 
MATSCHINSKY, F. M.; GLASER, B.; MAGNUSON, M. A. Pancreatic beta-cell glucokinase: Closing the gap between theoretical concepts and experimental realities. Diabetes, v. 47, n. 3, p. 307-315, 1998.

MCGUIRE, M. C.; FIELDS, R. M.; NYOMBA, B. L.; RAZ, I.; BOGARDUS, C.; TONKS, N. K.; SOMMERCORN, J. Abnormal regulation of protein tyrosine phosphatase activities in skeletal muscle of insulin-resistant humans. Diabetes, v. 40, n. 7, p. 939-942, 1991.

MICHALIK, L.; WAHLI, W. Peroxisome proliferator-activated receptors: Three isotypes for a multitude of functions. Curr. Opin. Biotechnol., v. 10, n. 6, p. 564-570, 1999.

MONTE, M. J.; MARIN, J. J.; ANTELO, A.; VAZQUEZ-TATO, J. Bile acids: Chemistry, physiology, and pathophysiology. World J. Gastroenterol., v. 15, n. 7, p. 804-816, 2009.

MONTELL, E.; TURINI, M.; MAROTTA, M.; ROBERTS, M.; NOE, V.; CIUDAD, C. J.; MACE, K.; GOMEZ-FOIX, A. M. Dag accumulation from saturated fatty acids desensitizes insulin stimulation of glucose uptake in muscle cells. Am. J. Physiol. Endocrinol. Metab., v. 280, n. 2, p. E229-E237, 2001.

MOURATOFF, G. J.; CARROLL, N. V.; SCOTT, E. M. Diabetes mellitus in eskimos. JAMA, v. 199, n. 13, p. 107-112, 1967.

NAKAMURA, K.; HANDA, S. Coomassie brilliant blue staining of lipids on thin-layer plates. Anal. Biochem., v. 142, n. 2, p. 406-410, 1984.

NAKATANI, T.; KIM, H. J.; KABURAGI, Y.; YASUDA, K.; EZAKI, O. A low fish oil inhibits srebp-1 proteolytic cascade, while a high-fish-oil feeding decreases srebp-1 mrna in mice liver: Relationship to anti-obesity. J. Lipid Res., v. 44,. n. 2, p. 369-379, 2003.

NEAT, C. E.; THOMASSEN, M. S.; OSMUNDSEN, H. Effects of high-fat diets on hepatic fatty acid oxidation in the rat. Isolation of rat liver peroxisomes by verticalrotor centrifugation by using a self-generated, iso-osmotic, percoll gradient. Biochem. J., v. 196, n. 1, p. 149-159, 1981.

NESCHEN, S.; MOORE, I.; REGITTNIG, W.; YU, C. L.; WANG, Y.; PYPAERT, M.; PETERSEN, K. F.; SHULMAN, G. I. Contrasting effects of fish oil and safflower oil on 
hepatic peroxisomal and tissue lipid content. Am. J. Physiol. Endocrinol. Metab., v. 282, n. 2, p. E395-E401, 2002.

NYSTROM, F. H.; CHEN, H.; CONG, L. N.; LI, Y.; QUON, M. J. Caveolin-1 interacts with the insulin receptor and can differentially modulate insulin signaling in transfected cos-7 cells and rat adipose cells. Mol. Endocrinol., v. 13, n. 12, p. 2013-2024, 1999.

NYSTROM, F. H.; QUON, M. J. Insulin signalling: Metabolic pathways and mechanisms for specificity. Cell. Signal. v. 11, n. 8, p. 563-574, 1999.

OAKES, N. D.; COONEY, G. J.; CAMILLERI, S.; CHISHOLM, D. J.; KRAEGEN, E. $W$. Mechanisms of liver and muscle insulin resistance induced by chronic high-fat feeding. Diabetes, v. 46, n. 11, p. 1768-1774, 1997.

OKADA, T.; FURUHASHI, N.; KUROMORI, Y.; MIYASHITA, M.; IWATA, F.; HARADA, K. Plasma palmitoleic acid content and obesity in children. Am. J. Clin. Nutr., v. 82, n. 4, p. 747-750, 2005.

OTTO, D. A.; BALTZELL, J. K.; WOOTEN, J. T. Reduction in triacylglycerol levels by fish oil correlates with free fatty acid levels in ad libitum fed rats. Lipids, v. 27, n. 12, p. 1013-1017, 1992.

PACHIKIAN, B. D.; NEYRINCK, A. M.; CANI, P. D.; PORTOIS, L.; DELDICQUE, L.; DE BACKER, F. C.; BINDELS, L. B.; SOHET, F. M.; MALAISSE, W. J.; FRANCAUX, M.; CARPENTIER, Y. A.; DELZENNE, N. M. Hepatic steatosis in n-3 fatty acid depleted mice: Focus on metabolic alterations related to tissue fatty acid composition. BMC Physiol., v. 8, p. 21, 2008.

PAILLARD, F.; CATHELINE, D.; DUFF, F. L.; BOURIEL, M.; DEUGNIER, Y.; POUCHARD, M.; DAUBERT, J. C.; LEGRAND, P. Plasma palmitoleic acid, a product of stearoyl-CoA desaturase activity, is an independent marker of triglyceridemia and abdominal adiposity. Nutr. Metab. Cardiovasc. Dis., v. 18, n. 6, p. 436-440, 2008.

PARPAL, S.; KARLSSON, M.; THORN, H.; STRALFORS, P. Cholesterol depletion disrupts caveolae and insulin receptor signaling for metabolic control via insulin receptor substrate-1, but not for mitogen-activated protein kinase control. J. Biol. Chem., v. 276, n. 13, p. 9670-9678, 2001.

PARRISH, C. C.; PATHY, D. A.; ANGEL, A. Dietary fish oils limit adipose tissue hypertrophy in rats. Metabolism, v. 39, n. 3, p. 217-219, 1990. 
PARRISH, C. C.; PATHY, D. A.; PARKES, J. G.; ANGEL, A. Dietary fish oils modify adipocyte structure and function. J. Cell. Physiol., v. 148, n. 3, p. 493-502, 1991.

PEOPLES, G. E.; MCLENNAN, P. L. Dietary fish oil reduces skeletal muscle oxygen consumption, provides fatigue resistance and improves contractile recovery in the rat in vivo hindlimb. Br. J. Nutr., v. 104, n. 12, p. 1771-1779, 2010.

PEOPLES, G. E.; MCLENNAN, P. L.; HOWE, P. R.; GROELLER, H. Fish oil reduces heart rate and oxygen consumption during exercise. J. Cardiovasc. Pharmacol., v. 52 , n. 6 , p. 540-547, 2008.

PERSEGHIN, G.; PETERSEN, K.; SHULMAN, G. I. Cellular mechanism of insulin resistance: Potential links with inflammation. Int. J. Obes. Relat. Metab. Disord., v. 27, p. S6-S11, 2003. Suppl 3.

PFEILSCHIFTER, J.; HUWILER, A. Ceramides as key players in cellular stress response. News Physiol. Sci., v. 15, p. 11-15, 2000.

PIGHIN, D.; KARABATAS, L.; ROSSI, A.; CHICCO, A.; BASABE, J. C.; LOMBARDO, Y. B. Fish oil affects pancreatic fat storage, pyruvate dehydrogenase complex activity and insulin secretion in rats fed a sucrose-rich diet. J. Nutr., v. 133, n. 12, p. 4095-4101, 2003.

POMPÉIA, C. Essencialidade dos ácidos graxos. In: CURI, R. (Ed.). Entendendo a gordura - os ácidos graxos. Barueri: Editora Manole, 2002. p. Xx-xx.

PRONK, G. J.; MCGLADE, J.; PELICCI, G.; PAWSON, T.; BOS, J. L. Insulin-induced phosphorylation of the 46- and 52-kda shc proteins. J Biol Chem., v. 268, n. 8, p. 5748-5753, 1993.

QUON, M. J.; CHEN, H.; ING, B. L.; LIU, M. L.; ZARNOWSKI, M. J.; YONEZAWA, K.; KASUGA, M.; CUSHMAN, S. W.; TAYLOR, S. I. Roles of 1-phosphatidylinositol 3kinase and ras in regulating translocation of glut4 in transfected rat adipose cells. Mol. Cell. Biol., v. 15, n. 10, p. 5403-5411, 1995.

RANDLE, P. J.; GARLAND, P. B.; HALES, C. N.; NEWSHOLME, E. A. The glucose fatty-acid cycle. Its role in insulin sensitivity and the metabolic disturbances of diabetes mellitus. Lancet, v. 1, p. 785-789, 1963. 
RAZANI, B.; LISANTI, M. P. Caveolin-deficient mice: Insights into caveolar function human disease. J. Clin. Invest., v. 108, n. 11, p. 1553-1561, 2001.

RAZANI, B.; RUBIN, C. S.; LISANTI, M. P. Regulation of camp-mediated signal transduction via interaction of caveolins with the catalytic subunit of protein kinase a. J. Biol. Chem., v. 274, n. 37, p. 26353-26360, 1999.

REDDY, J. K.; HASHIMOTO, T. Peroxisomal beta-oxidation and peroxisome proliferator-activated receptor alpha: An adaptive metabolic system. Annu. Rev. Nutr., v. 21 , p. 193-230, 2001.

REN, B.; THELEN, A. P.; PETERS, J. M.; GONZALEZ, F. J.; JUMP, D. B. Polyunsaturated fatty acid suppression of hepatic fatty acid synthase and s14 gene expression does not require peroxisome proliferator-activated receptor alpha. J. Biol. Chem., v. 272, n. 43, p. 26827-26832, 1997.

Research Diets. www.researchdiets.com. Acessado em 27 de março de 2011.

RIECKENHOFF, I. G.; HOLMAN, R. T.; BURR, G. O. Polyethenoid fatty acid metabolism; effect of dietary fat on polyethenoid fatty acids of rat tissues. Arch. Biochem., v. 20, n. 2, p. 331-340, 1949.

ROSEN, E. D.; SPIEGELMAN, B. M. Ppargamma: A nuclear regulator of metabolism, differentiation, and cell growth. J. Biol. Chem., v. 276, n. 41, p. 37731-37734, 2001.

SATO, A.; KAWANO, H.; NOTSU, T.; OHTA, M.; NAKAKUKI, M.; MIZUGUCHI, K.; ITOH, M.; SUGANAMI, T.; OGAWA, Y. Antiobesity effect of eicosapentaenoic acid in high-fat/high-sucrose diet-induced obesity: Importance of hepatic lipogenesis. Diabetes, v. 59, n. 10, p. 2495-2504, 2010.

SCHLEGEL, A.; SCHWAB, R. B.; SCHERER, P. E.; LISANTI, M. P. A role for the caveolin scaffolding domain in mediating the membrane attachment of caveolin-1. The caveolin scaffolding domain is both necessary and sufficient for membrane binding in vitro. J. Biol. Chem., v. 274, n. 32, p. 22660-22667, 1999.

SCHMITZ-PEIFFER, C. Signalling aspects of insulin resistance in skeletal muscle: Mechanisms induced by lipid oversupply. Cell. Signal., v. 12, n. 9-10, p. 583-594, 2000. 
SCHMITZ-PEIFFER, C.; BROWNE, C. L.; OAKES, N. D.; WATKINSON, A.; CHISHOLM, D. J.; KRAEGEN, E. W.; BIDEN, T. J. Alterations in the expression and cellular localization of protein kinase $\mathrm{c}$ isozymes epsilon and theta are associated with insulin resistance in skeletal muscle of the high-fat-fed rat. Diabetes, v. 46, n. 2 , p. 169-178, 1997.

SCHMITZ-PEIFFER, C.; CRAIG, D. L.; BIDEN, T. J. Ceramide generation is sufficient to account for the inhibition of the insulin-stimulated pkb pathway in $\mathrm{c} 2 \mathrm{c} 12$ skeletal muscle cells pretreated with palmitate. J. Biol. Chem., v. 274, n. 34, p. 24202-24210, 1999.

SCHOONJANS, K.; STAELS, B.; AUWERX, J. The peroxisome proliferator activated receptors (ppars) and their effects on lipid metabolism and adipocyte differentiation. Biochim. Biophys. Acta, v. 1302, n. 2, p. 93-109, 1996.

SCHRADER, M.; FAHIMI, H. D. The peroxisome: Still a mysterious organelle. Histochem. Cell. Biol., v. 129, n. 4, p. 421-440, 2008.

SEIDELL, J. C. Obesity, insulin resistance and diabetes--a worldwide epidemic. Br. J. Nutr., v. 83, p. S5-S8, 2000. Suppl 1.

SESSLER, A. M.; NTAMBI, J. M. Polyunsaturated fatty acid regulation of gene expression. J. Nutr., v. 128, n. 6, p. 923-926, 1998.

SHULMAN, G. I. Cellular mechanisms of insulin resistance. J. Clin. Invest., v. 106, n. 2, p. 171-176, 2000.

SIMONCIKOVA, P.; WEIN, S.; GASPERIKOVA, D.; UKROPEC, J.; CERTIK, M.; KLIMES, I.; SEBOKOVA, E. Comparison of the extrapancreatic action of gammalinolenic acid and n-3 pufas in the high fat diet-induced insulin resistance [corrected]. Endocr. Regul., v. 36, n. 4, p. 143-149, 2002.

SINAL, C. J.; TOHKIN, M.; MIYATA, M.; WARD, J. M.; LAMBERT, G.; GONZALEZ, F. J. Targeted disruption of the nuclear receptor $\mathrm{fxr} / \mathrm{bar}$ impairs bile acid and lipid homeostasis. Cell, v. 102, n. 6, p. 731-744, 2000.

SKOLNIK, E. Y.; BATZER, A.; LI, N.; LEE, C. H.; LOWENSTEIN, E.; MOHAMMADI, M.; MARGOLIS, B.; SCHLESSINGER, J. The function of grb2 in linking the insulin receptor to ras signaling pathways. Science, v. 260, n. 5116, p. 1953-1955, 1993. 
SMELAND, T. E.; NADA, M.; CUEBAS, D.; SCHULZ, H. Nadph-dependent betaoxidation of unsaturated fatty acids with double bonds extending from odd-numbered carbon atoms. Proc. Natl. Acad. Sci. U S A, v. 89, n. 15, p. 6673-6677, 1992.

SOLTYS, C. L.; BUCHHOLZ, L.; GANDHI, M.; CLANACHAN, A. S.; WALSH, K.; DYCK, J. R. Phosphorylation of cardiac protein kinase $\mathrm{b}$ is regulated by palmitate. Am. J. Physiol. Heart Circ. Physiol., v. 283, n. 3, p. H1056-H1064, 2002.

SOMWAR, R.; KIM, D. Y.; SWEENEY, G.; HUANG, C.; NIU, W.; LADOR, C.; RAMLAL, T.; KLIP, A. Glut4 translocation precedes the stimulation of glucose uptake by insulin in muscle cells: Potential activation of glut4 via p38 mitogen-activated protein kinase. Biochem. J., v. 359, pt 3, p. 639-649, 2001.

STAVINOHA, M. A.; RAYSPELLICY, J. W.; ESSOP, M. F.; GRAVELEAU, C.; ABEL, E. D.; HART-SAILORS, M. L.; MERSMANN, H. J.; BRAY, M. S.; YOUNG, M. E. Evidence for mitochondrial thioesterase 1 as a peroxisome proliferator-activated receptor-alpha-regulated gene in cardiac and skeletal muscle. Am. J. Physiol. Endocrinol. Metab., v. 287, n. 5, p. E888-E895, 2004.

STORLIEN, L. H.; JENKINS, A. B.; CHISHOLM, D. J.; PASCOE, W. S.; KHOURI, S.; KRAEGEN, E. W. Influence of dietary fat composition on development of insulin resistance in rats. Relationship to muscle triglyceride and omega-3 fatty acids in muscle phospholipid. Diabetes, v. 40, n. 2, p. 280-289, 1991.

STRYER, L. Biochemistry. $3^{\text {rd }}$ ed. New York: W. H. Freeman and Company, 1988.

SUMMERS, S. A.; YIN, V. P.; WHITEMAN, E. L.; GARZA, L. A.; CHO, H.; TUTTLE, R. L.; BIRNBAUM, M. J. Signaling pathways mediating insulin-stimulated glucose transport. Ann. N Y Acad. Sci., v. 892, p. 169-186, 1999.

SUN, C.; WEI, Z. W.; LI, Y. Dha regulates lipogenesis and lipolysis genes in mice adipose and liver. Mol. Biol. Rep., v. 38, n. 2, p. 731-737, 2010.

SVOBODA, D. J.; AZARNOFF, D. L. Response of hepatic microbodies to a hypolipidemic agent, ethyl chlorophenoxyisobutyrate (cpib). J. Cell. Biol., v. 30, n. 2, p. 442-450, 1966.

TAKEUCHI, H.; KOJIMA, K.; SEKINE, S.; MURANO, Y.; AOYAMA, T. Effect of dietary $n-6 / n-3$ ratio on liver $n-6 / n-3$ ratio and peroxisomal beta-oxidation activity in rats. J. Oleo. Sci., v. 57, n. 12, p. 649-657, 2008. 
TANG, Z.; SCHERER, P. E.; OKAMOTO, T.; SONG, K.; CHU, C.; KOHTZ, D. S.; NISHIMOTO, I.; LODISH, H. F.; LISANTI, M. P. Molecular cloning of caveolin-3, a novel member of the caveolin gene family expressed predominantly in muscle. $J$. Biol. Chem., v. 271, n. 4, p. 2255-2261, 1996.

THOMPSON, A. L.; LIM-FRASER, M. Y.; KRAEGEN, E. W.; COONEY, G. J. Effects of individual fatty acids on glucose uptake and glycogen synthesis in soleus muscle in vitro. Am. J. Physiol. Endocrinol. Metab., v. 279, n. 3, p. E577-E584, 2000.

TOTLAND, G. K.; MADSEN, L.; KLEMENTSEN, B.; VAAGENES, H.; KRYVI, H.; FROYLAND, L.; HEXEBERG, S.; BERGE, R. K. Proliferation of mitochondria and gene expression of carnitine palmitoyltransferase and fatty acyl-CoA oxidase in rat skeletal muscle, heart and liver by hypolipidemic fatty acids. Biol. Cell., v. 92, n. 5, p. 317-329, 2000.

TRAUNER, M.; CLAUDEL, T.; FICKERT, P.; MOUSTAFA, T.; WAGNER, M. Bile acids as regulators of hepatic lipid and glucose metabolism. Dig. Dis., v. 28, n. 1, p. 220-224, 2010.

TURNER, N.; BRUCE, C. R.; BEALE, S. M.; HOEHN, K. L.; SO, T.; ROLPH, M. S.; COONEY, G. J. Excess lipid availability increases mitochondrial fatty acid oxidative capacity in muscle: Evidence against a role for reduced fatty acid oxidation in lipidinduced insulin resistance in rodents. Diabetes, v. 56, n. 8, p. 2085-2092, 2007.

USUI, I.; TAKATA, Y.; IMAMURA, T.; MORIOKA, H.; SASAOKA, T.; SAWA, T.; ISHIHARA, H.; ISHIKI, M.; KOBAYASHI, M. Fatty acid induced insulin resistance in rat-1 fibroblasts overexpressing human insulin receptors: Impaired insulin-stimulated mitogen-activated protein kinase activity. Diabetologia, v. 40, n. 8, p. 894-901, 1997.

VAMECQ, J.; VALLEE, L.; DE LA PORTE, P. L.; FONTAINE, M.; DE CRAEMER, D.; VAN DEN BRANDEN, C.; LAFONT, H.; GRATAROLI, R.; NALBONE, G. Effect of various $n-3 / n-6$ fatty acid ratio contents of high fat diets on rat liver and heart peroxisomal and mitochondrial beta-oxidation. Biochim. Biophys. Acta, v. 1170, n. 2, p. 151-156, 1993.

VAN EPPS-FUNG, M.; WILLIFORD, J.; WELLS, A.; HARDY, R. W. Fatty acidinduced insulin resistance in adipocytes. Endocrinology, v. 138, n. 10, p. 4338-4345, 1997.

VAN VELDHOVEN, P. P.; VANHOVE, G.; ASSSELBERGHS, S.; EYSSEN, H. J.; MANNAERTS, G. P. Substrate specificities of rat liver peroxisomal acyl-CoA oxidases: Palmitoyl-CoA oxidase (inducible acyl-CoA oxidase), pristanoyl-CoA oxidase (non-inducible acyl-CoA oxidase), and trihydroxycoprostanoyl-CoA oxidase. J. Biol. Chem., v. 267, n. 28, p. 20065-20074, 1992. 
VANHOVE, G. F.; VAN VELDHOVEN, P. P.; FRANSEN, M.; DENIS, S.; EYSSEN, H. J.; WANDERS, R. J.; MANNAERTS, G. P. The CoA esters of 2-methyl-branched chain fatty acids and of the bile acid intermediates di- and trihydroxycoprostanic acids are oxidized by one single peroxisomal branched chain acyl-CoA oxidase in human liver and kidney. J. Biol. Chem., v. 268, n. 14, p. 10335-10344, 1993.

VOLYNETS, V.; SPRUSS, A.; KANURI, G.; WAGNERBERGER, S.; BISCHOFF, S. C.; BERGHEIM, I. Protective effect of bile acids on the onset of fructose-induced hepatic steatosis in mice. J. Lipid. Res. v. 12, n. 52, p. 3414-3424, 2010.

WAKIL, S. J.; STOOPS, J. K.; JOSHI, V. C. Fatty acid synthesis and its regulation. Annu. Rev. Biochem., v. 52, p. 537-579, 1983.

WAKUTSU, M,; TSUNODA, N.; SHIBA, S.; MURAKI, E.; KASONO, K. Peroxisome proliferator-activated receptors (PPARs)-independent functions of fish oil on glucose and lipid metabolism in diet-induced obese mice. Lipids in Health and Disease, v. 9, p. 101-110, 2010.

WANDERS, R. J.; VREKEN, P.; DEN BOER, M. E.; WIJBURG, F. A.; VAN GENNIP, A. H.; L, I. J. Disorders of mitochondrial fatty acyl-CoA beta-oxidation. J. Inherit. Metab. Dis., v. 22, n. 4, p. 442-487, 1999.

WANDERS, R. J.; VREKEN, P.; FERDINANDUSSE, S.; JANSEN, G. A.; WATERHAM, H. R.; VAN ROERMUND, C. W.; VAN GRUNSVEN, E. G. Peroxisomal fatty acid alpha- and beta-oxidation in humans: Enzymology, peroxisomal metabolite transporters and peroxisomal diseases. Biochem. Soc. Trans., v. 29, n. pt 2, p. 250-267, 2001.

WEST, D. B.; BOOZER, C. N.; MOODY, D. L.; ATKINSON, R. L. Dietary obesity in nine inbred mouse strains. Am. J. Physiol., v. 262, n. 6 pt 2, p. R1025-R1032, 1992.

WILLUMSEN, N.; HEXEBERG, S.; SKORVE, J.; LUNDQUIST, M.; BERGE, R. K. Docosahexaenoic acid shows no triglyceride-lowering effects but increases the peroxisomal fatty acid oxidation in liver of rats. J. Lipid Res., v. 34, n. 1, p. 13-22, 1993.

WONG, D. A.; BASSILIAN, S.; LIM, S.; PAUL LEE, W. N. Coordination of peroxisomal beta-oxidation and fatty acid elongation in hepg2 cells. J. Biol. Chem., v. 279, n. 40, p. 41302-41309, 2004. 
YANO, Y.; SUMIDA, Y.; BENZING, C. F.; ROBINSON, F. W.; KONO, T. Primary sites of actions of staurosporine and h-7 in the cascade of insulin action to glucose transport in rat adipocytes. Biochim. Biophys. Acta, v. 1176, n. 3, p. 327-332, 1993.

YU, C.; CHEN, Y.; CLINE, G. W.; ZHANG, D.; ZONG, H.; WANG, Y.; BERGERON, R.; KIM, J. K.; CUSHMAN, S. W.; COONEY, G. J.; ATCHESON, B.; WHITE, M. F.; KRAEGEN, E. W.; SHULMAN, G. I. Mechanism by which fatty acids inhibit insulin activation of insulin receptor substrate-1 (irs-1)-associated phosphatidylinositol 3kinase activity in muscle. J. Biol. Chem., v. 277, n. 52, p. 50230-50236, 2002. 